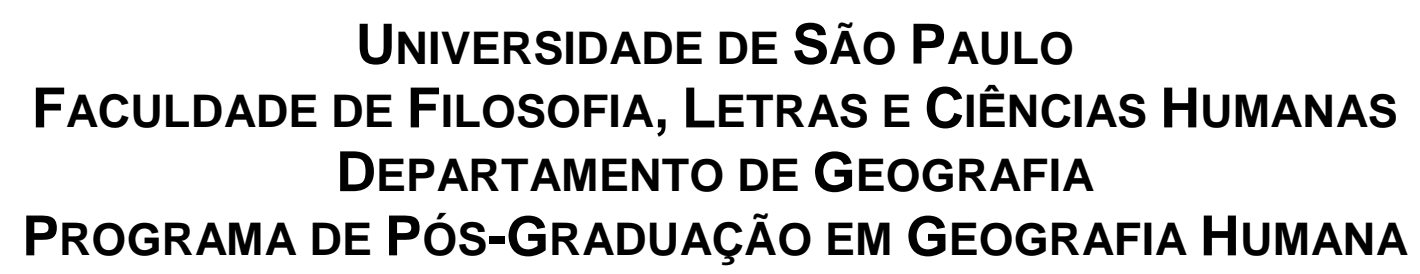

FILIPE GIUSEPPE DAL BO RIBEIRO

\title{
A Nova Geografia MiLitar: LogísticA, Estratégia E INTELIGÊNCIA
}




\author{
UNIVERSIDADE DE SÃo PAULO \\ FACULDADE DE FILOSOFIA, LETRAS E CIÊNCIAS HuMANAS \\ DEPARTAMENTO DE GEOGRAFIA \\ Programa de Pós-Graduação em Geografia Humana
}

\title{
A Nova Geografia Militar: Logística, Estratégia E INTELIGÊNCIA
}

FILIPE GIUSEPPE DAL Bo RIBEIRO

Dissertação apresentada ao Programa de PósGraduação em Geografia Humana, do Departamento de Geografia da Faculdade de Filosofia, Letras e Ciências Humanas da Universidade de São Paulo, para obtenção do título de Mestre em Geografia Humana.

Orientador: Professor Doutor André Roberto Martin

São Paulo

2010 
Dedico este trabalho a minha querida esposa, Fabiana

Cunha.

A sua fé e força mostrou que a vida vale apena ser vivida. 


\section{RESUMO}

O presente trabalho tem como propósito estabelecer parâmetros de um campo pouco estudado pela ciência geográfica, a geografia militar. O conceito da geografia militar está relacionado com aspecto histórico de cada lugar e não está relacionado a uma escola de pensamento específica, não só a escola de pensamento geográfico, mas às escolas de pensamento marciais, portanto o propósito central é aprimorar e expandir o arcabouço teórico e metodológico da própria geografia. Não se trata aqui de realizar uma história da geografia militar, mas o presente trabalho tem como finalidade demonstrar o papel da geografia como aspecto mais concreto do fenômeno da guerra, da logística, da estratégia e da inteligência. Os temas estratégicos, embora pouco freqüentes na pesquisa geográfica brasileira ultimamente, são cada vez mais comuns em outras áreas do conhecimento, notadamente entre economistas, administradores, e claro, cientistas políticos. A importância de estudarmos a geografia sobre estes aspectos nos permite detectar se a evolução desta ciência influenciou nas concepções da tática e da estratégia; a correspondente relação entre geoestratégia e geopolítica; analisar conflitos específicos como a guerrilha, o terrorismo, a guerra nuclear, a guerra tática e confrontos de outras ordens. A geografia militar está relacionada com a condução das operações militares. Por outro lado, a geopolítica está mais relacionada às estratégias, por ser mais ideológica do que prática, portanto a geografia militar é a prática que viabiliza a estratégia. Por fim, será feita uma análise na nova geografia militar empregada pelo novo imperialismo mundial.

\section{PALAVRAS-CHAVE:}

Geografia militar, geopolítica, geoestratégia, logística, inteligência. 


\section{ABSTRACT}

This research aims to establish parameters of an area that was little studied by the geographical science, the military geography. The concept of the military geography is related to the historic aspect of each place and it is not related to an specific school of thought, not only to the school of geographical thought, but to the schools of martial thoughts, thus the central proposal is to improve and expand the theoretical and methodological frame of reference of the proper geographical science. This research aims to demonstrate the role of geography as a more concrete aspect of the war phenomenon, of logistics, of strategy and intelligence. The strategic themes, although less frequent in the Brazilian geographical research lately, are increasingly common in other areas of knowledge, especially among economists, administrators and certainly among political scientists. The importance of studying geography under these aspects allows us to detect if the evolution of this science influenced in the conceptions of tactic and strategy; the corresponding relationship between geo strategy and geopolitics; to analyze specific conflicts such as guerrilla, terrorism, nuclear war, the tactic war and confrontations of other natures. The military geography is related to the conduct of the military operations. On the other hand, geopolitics is more related to strategies because it is more ideological than practical, therefore the military geography is the practice that enables the strategy. Finally, we will analyze the new military geography employed by the new worldwide imperialism.

\section{KEY WORDS:}

Military geography, geopolitics, geostrategic, logistics, intelligence 


\section{SUMÁRIO}

CAPÍTULO I: A geografia militar: seu escopo e sua relação com as ciências militares 11

CAPÍTULO II: Geografia militar e Geopolítica: o caminho da ideologia à estratégia e (ou) da tática à prática 25

CAPÍTULO III: Da arte da guerra à ciência da guerra: as teorias da guerra e suas concepções geográficas 48

CAPÍTULO IV: O novo imperialismo e sua nova geografia militar: a sua logística, estratégia e inteligência. 79

CONSIDERAÇOES FINAIS: A geografia militar versus o militarismo 108 


\section{1- Apresentacão}

A proposta de nosso trabalho é estabelecer parâmetros de um conceito pouco estudado pela geografia universitária, ou como diz o professor Lacoste, a geografia dos professores: A geografia militar. Esta disciplina tão antiga quanto a própria guerra surgiu antes da geografia científica que nasceu no século XIX, "mas os universitários de hoje consideram, todos, quaisquer que sejam suas tendências ideológicas, que a verdadeira geografia, só aparece no século XIX, com os trabalhos de Humboldt" (LACOSTE: 2008, 25). Essa questão de quando surge a geografia como ciência é bem controversa, mas com qual intuito foi usado os levantamentos de Humboldt no México? Essa é uma questão muito mais interessante, principalmente quando se sabe que antes de voltar de sua antológica viagem pelas Américas, Humboldt, passou pelos Estados Unidos e em conferência com o presidente Jeferson disponibilizou os seus mapeamentos sobre áreas que mais tarde seriam conquistadas muito facilmente pelos estadunidenses.

Parece que o conceito de geografia militar está relacionado com aspectos históricos de cada lugar e é por isso que se chama geografia militar que está relacionada a uma escola de pensamento específica que é específico de cada país, por exemplo, os chineses, os americanos, os franceses, ou seja, são escolas de geografia e até muito mais abrangente que escola de geografia propriamente dita, porque normalmente a nossa escola de geografia esta presa a escola de pensamento europeu e americano, então, no presente trabalho, é feito um aporte do pensamento chinês, isto é interessante porque o viés da geografia militar nos permite fazer uma abrangência maior de reflexões e não se prende as tradicionais escolas que fazem parte do arcabouço teórico-metodológico da geografia o que a deixa, de certa forma limitada. Portanto, o viés da geografia militar, por permitir esta abertura, é a própria importância em termos conceituais para o interior da ciência geográfica, enriquecendo o temário da geografia e conseqüentemente, o presente trabalho, abarca outros temas que não eram tão esperados, aprimorando metodologicamente e epistemologicamente a ciência geográfica. Yves Lacoste é um crítico desta limitação, porque ele escreveu o livro? Porque 
ele acha que a geografia se negou a fazer uma reflexão política sobre o espaço e ficou pequena epistemologicamente.

A tarefa do presente trabalho é bastante árdua visto que a geografia brasileira, ainda hoje, sofre de sérios traumas do período do regime militar que atingiu diretamente as ciências humanas. Acreditamos que propor um trabalho de Geografia Militar no Departamento de Geografia da Universidade de São Paulo seja tão difícil quanto foi para Yves Lacoste escrever seu ensaio sobre a geografia. Tudo que é intitulado "militar" tem suas complicações às vezes mais psicológicas do que científicas. Mas não podemos simplesmente colocar uma questão tão importante, que envolve principalmente a "Questão da Defesa Nacional", de lado e fingir que nunca existiu e que esta também não é um assunto da geografia, ora a geografia como ciência pode trazer subsídios para discussão de maneira "crítica", por ser uma ciência que analisa o espaço, território, paisagem, lugar entre outras categorias de análise com uma visão holística dos fenômenos naturais e humanos associando-os. De maneira semelhante observamos no campo da Geopolítica que ao ser rotulado de "coisa de milico" não foi mais estudada pela geografia ficando na mão apenas das escolas militares (TRAVASSOS, COUTO E SILVA, MEIRA MATOS) e nas últimas décadas resgatada pelos cientistas políticos (MELLO, MYAMOTO, etc). A geografia acadêmica teve suas contribuições sobre 0 assunto principalmente com os trabalhos da Professora Bertha K. BECKER, Professor Wanderlei Messias da COSTA e Professor André Roberto MARTIN, entre outros. Mas ainda existe uma lacuna nos estudos mais específicos da Geografia Militar e é sobre isso que será tratado na seguinte dissertação.

No trabalho iremos trabalhar a importância histórica do conhecimento geográfico como conhecimento estratégico. Os primórdios do que LACOSTE chama de geografia do estado maior e a ciência militar chama de geografia militar será desenvolvida com base teórica de autores referência sobre o assunto. A História da Guerra e a Inteligência da Guerra de John KEEGAN; La Geografia y La Guerra de Fernando Pinto CEBRIAN; Military Geography de PELTIER \& PEARCY. 
Não se trata aqui de realizar uma história da geografia militar, mas o presente trabalho tem como finalidade demonstrar 0 papel da geografia como aspecto mais concreto do fenômeno da guerra, da logística, da estratégia e da inteligência. A importância de estudarmos a geografia sobre estes aspectos nos permite detectar se a evolução desta ciência influenciou nas concepções das táticas e estratégias; a correspondente relação entre geoestratégia e geopolítica; analisar conflitos específicos como a guerrilha, o terrorismo, a guerra nuclear, a guerra tática e confrontos de outras ordens.

Muitos trabalhos sobre geografia da antiguidade como de Heródoto e Estrabão com seu estilo descritivo das regiões, povos, acidentes orográficos, hidrografia, vegetação, estradas, caminhos, recursos naturais serviram, posteriormente, para prática não só dos navegantes, mas também de muitos generais que se aproveitaram desses estudos antes e durante suas campanhas, o que colocou a geografia muito antes de se tornar uma ciência num conhecimento de grande importância.

\section{Aporte teórico-metodológico}

A Geografia Militar era uma das especialidades práticas da Geografia, juntamente com a Geografia Médica e a Geografia Comercial, até o surgimento do revolucionário "determinismo" de Friedrich Ratzel. Com sua Geografia Política (1898) ele ampliou de tal modo o escopo da Geografia Militar, que esta viu-se reduzida a mera técnica, no entanto de emprego universal. Os temas estratégicos, embora pouco freqüentes na pesquisa geográfica brasileira ultimamente, são cada vez mais comuns em outras áreas do conhecimento, notadamente entre economistas, administradores, e claro, cientistas políticos.

A pesquisa proposta visa resgatar a experiência esquecida da geografia militar na geografia acadêmica, no que ela contribuiu para a formação dos estados territoriais e para o patrimônio cultural 
da cada nação. Sob esse ângulo, trata-se de um estudo antes de tudo, de Geografia Histórica. Por outro lado, pretende-se interrogar também até que ponto as necessidades "modernas" de defesa, que incluem inescapavelmente a constituição de um parque industrial bélico, acomodaram-se ou opuseram-se àquela herança logística que vinha se constituindo desde a Colônia e o Império. Nesse sentido, configura-se como uma pesquisa de Geopolítica, com ênfase na sua aplicação prática em termos de políticas territoriais. A "decisão local" em ambos os casos, vale sublinhar, está presidida por paradigmas não contemplados pelas teorias geoeconômicas, como as de Von Thünen ou Christaller por exemplo, já que o binômio defesa/ataque possui aqui, maior relevância que a equação tradicional de custo/benefício. Daí a importância da reconstituição histórica e cartográfica, e do cotejamento entre as doutrinas e realizações desses dois ramos da Geografia.

Philipe Boulanger (2005) nos chama a atenção para o fato de que a ciência geográfica começa a ser estudada pelas escolas de oficiais do exército francês no início do século XIX, e estes logo utilizarão os seus conhecimentos recém-adquiridos, na aplicação de técnicas e estratégias militares. Na primeira metade do século XIX, a disciplina Geografia Militar começa a ser ensinada na formação da elite militar francesa na Escola Especial de Sain-Cyr pelo professor Théophile Lavallée. Este organiza os primeiros fundamentos da disciplina em seu livro "Geógraphie physique, historique militaire", publicado em 1832. Depois da humilhante derrota francesa na guerra Franco-Alemã 1870-71, a geografia passou a fazer parte definitiva da cultura militar. Portanto, podemos afirmar que Lavallée e sua Geografia Militar são os antecessores legítimos da Geografia Política e da Antropogeografia, desenvolvidas por Ratzel na segunda metade do Século XIX. O termo é também anterior a Geopolítica - conceito desenvolvido por Kjéllen em 1916. 


\section{CAPÍTULO 1}

\section{A GEOGRAFIA MILITAR E SEU ESCOPO E SUA RELAÇÃO COM AS CIÊNCIAS MILITARES.}

\section{Introdução}

O conhecimento do território é uma das matérias fundamentais que todo o comandante e seus encarregados devem estudar, é importante desde o comando das menores unidades de combate até nos mais altos escalões, onde se discute a estratégia e se desenvolve o conhecimento da geografia. Não podemos considerar apenas as condições do terreno, mas do território com todas as suas complexidades, este último sempre foi de extrema importância na análise, estruturação e execução de qualquer problema bélico que se apresente. Toda solução a uma situação tática ou estratégica requerem o conhecimento prévio do cenário de onde vai se atuar.

A geografia militar surgiu como um ramo da geografia geral que estuda os fatores geográficos humanos, físicos, econômicos, políticos e militar e suas relações espaciais correspondente ao cenário de guerra, e interpretá-los para deduzir a influência que exercem na condição militar. Mas esta disciplina é tão antiga quanto à própria guerra e, certamente, mais antiga que a ciência geográfica universitária que é datada do século XIX, portanto, surgiu para apoiar ainda mais os impérios europeus em sua expansão, a partir de então, com o caráter mais cientificista. A geografia militar se orienta, sobretudo, para aproveitar as vantagens e avaliar os inconvenientes, que os fatores geográficos representam no cerne social da guerra, contribuindo como base fundamental para organização das forças armadas.

O uso dos conhecimentos sobre geografia ocorre desde os tempos muito antigos, mesmo antes do surgimento das primeiras civilizações quando as sociedades humanas tinham uma organização social mais simples como os clãs e tribos, por exemplo. O conhecimento de um lugar seguro como uma caverna ou mesmo uma fonte de água deveriam ser importantes para o desenvolvimento de determinados clãs ou tribos. As pinturas rupestres funcionavam como certa indicação de rotas de caças, portanto, de certa forma 
poderiam ser consideradas como a primeira tentativa de sistematizar o espaço, utilizando não símbolos sofisticados da cartografia moderna, mas usando a própria arte, assim, o ser humano diferenciou-se de outras espécies animais ao conseguir expressar seus sentimentos na forma de arte e reconhecer o espaço sistematizando-o em categorias, mesmo que de maneira mais simples.

\begin{abstract}
Desde tempos imemoriais, quando os grupos humanos pouco se diferenciavam de seus "primos" mais próximos, isto é, dos demais primatas superiores, saber a localização de uma fonte de água potável, ter acesso a um determinado campo de caça e protegê-lo contra eventuais invasores, representavam conhecimentos vitais que hoje nós provavelmente denominaríamos de estratégicos (...). Além disso, esse conjunto de informações, técnicas e métodos, podia ir sendo ampliado indefinidamente, desde que evidentemente, a memória coletiva tivesse capacidade de armazená-los de alguma forma. (MARTIN, 2004:15)
\end{abstract}

Considerado o primeiro tratado sobre a guerra a Arte da Guerra de Sun Tzu, como será pormenorizado adiante, descreve e analisa o período da Primavera e Outono (722-481 a.C). Nele, o famigerado estrategista, expõe de maneira brilhante questões sobre tática, estratégia, geografia (os sete tipos de terreno), e sobre as questões militares (organização, logística, disciplina). É verdade que os teóricos colocam em questão a existência de Sun Tzu, dizendo que ele talvez represente uma escola teórica marcial, assim como Sócrates entre os gregos, mas estas questões não serão discutidas neste trabalho e sim o conteúdo referente a geografia aplicada ao exercício marcial em sua época e a evolução do uso aplicado da geografia em diferentes momentos e referentes aos teórico mais eminentes de cada momento. "Alguém que não está familiarizado com as montanhas e florestas, gargantas e desfiladeiros, com a forma dos charcos e pantanais, não pode fazer avançar o exército. Quem não lança mão de guias locais não pode obter vantagens do terreno" (SUN TZU, 2006:91).

Entretanto, os pequenos destacamentos de bravos homens com um equipamento bélico bastante precário eram a máxima força que muitas das sociedades primitivas possuíam. Já algumas civilizações da antiguidade desenvolveram uma máquina de guerra bem mais organizada. $\mathrm{O}$ conhecimento 
geográfico utilizado para fins militares de maneira bem efetiva começa a ser desenvolvido por pensadores e utilizado pelos grandes imperadores como Alexandre, o grande. Na medida em que as civilizações humanas fizeram avanços tecnológicos, também, foram aprofundando sua organização militar e com isso a capacidade de sistematizar o conhecimento geográfico para fins bélicos.

\begin{abstract}
Visitantes estrangeiros vindos de terras distantes que mais tarde Alexandre, o Grande conquistaria recordam a insistência de suas perguntas a respeito do tamanho da população em seus países, da produtividade do solo, da direção dos rios e estradas que os atravessavam, da localização das cidades, baías e praças fortificadas e da identidade dos cidadãos importantes, feitas no tempo em que, ainda menino, ele reinava na corte da Macedônia na ausência de seu pai, Filipe, em campanha militar no exterior (KEEGAN, 2006: 25)
\end{abstract}

Os conhecimentos que mais adiante sofreram uma importante ampliação, como: o conhecimento de outros povos, suas posições, suas possibilidades em caso de guerra; tudo isto se produzirá de forma mais definitiva com o nascimento de uma política imperialista, que necessitará de uma política de defesa a qual irá aparecendo da intuição, ou das experiências em campo de batalha, concretizando cada vez mais os conhecimentos estratégicos, tal qual ocorreu com Alexandre, o Grande (356-323 a.C) que nesse sentido era cercado de sábios filósofos que tinham um vasto conhecimento geográfico, como Aristóteles, por exemplo. Entretanto o império romano chegou a tal especialização sobre a guerra que toda sua organização social direta ou indiretamente estava voltada para guerra e para o espetáculo da guerra.

Outro pensador de uma geografia militar antiga foi imperador Júlio Cesar (101-44 a.C), este foi muito astuto no uso de informações geográficas para defesa e conquista de seus inimigos, visto que o império romano era cercado de inimigos por todos os lados. Ele reuniu dados sobre a Gália, Bretanha e outros territórios antes de ocupá-los e desenvolveu um sistema de inteligência militar que servia de informações bastante precisas num raio de até trinta quilômetros do teatro da guerra. Sobre a Gália, César relatou: "A Gália está toda dividida em três partes: uma que habitam os belgas, outra os 
aquitanos, a terceira os que em sua língua se intitulam de celtas e na nossa de galos"1 (apud CEBRIAN, 1985:33). Cesar elaborara um sistema de inteligência em várias escalas: à curtas, médias e longas distâncias, "procursatores, que realizavam reconhecimento próximo, imediatamente à frente do exército; exploratores, batedores de longo alcance; e speculatores, que faziam espionagem nas profundezas do território do adversário" (KEEGAN, 2006: 27).

\section{O que é geografia militar?}

Algumas definições clássicas sobre a geografia militar devem ser mencionadas para esclarecer como este conceito evoluiu na ciência militar. Existem algumas definições advindas da ciência militar que afirmam de maneira simplista que a Geografia Militar é o ramo da ciência militar que tem por objetivo averiguar, discutir e estabelecer a influência no terreno das operações militares. Ora esta definição simplifica de maneira grotesca o conceito da ciência geográfica e a confundi com o estudo da topografia. Alguns autores fazem este tipo de confusão, mas também, é certo que a topografia foi um dos elementos da geografia mais desenvolvidos pela ciência militar, especialmente para infantaria e artilharia que estão diretamente atreladas a este conhecimento. É fundamental para ambas conhecer a topografia do terreno para realizar suas operações militares.

A definição de PORRO - autor de Guida allo studio della geografia militare; compendio delle lezioni di geografia militare. Torino: Unione tipografico-editrice,1898 - diz que a Geografia Militar é um estudo das influências dos elementos geográficos sobre a guerra. Esta definição coincide com os preceitos da escola determinista alemã que teve como principal teórico RATZEL que desenvolveu os conceitos da Geografia Política em sua clássica obra Politische Geographie editado pela primeira vez em 1897.

Os estudos dos elementos geográficos sobre a guerra colocam a geografia como determinante para o resultado da guerra. Não temos aqui o uso da geografia para influenciar o resultado da guerra, portanto, a geografia desta definição é um elemento que não pode ser superado de qualquer forma. As

\footnotetext{
${ }^{1}$ CEBRIAN, F. La Geografia Y La Guerra: "La Gália está toda dividida em tres partes: uma que habitan los belgas, outra los aquitanos, La tercera los que em su lengua se llaman celtas y em la nuestra galos...".
} 
sociedades humanas, na antiguidade, eram muito mais influenciadas pelos elementos geográficos do que as sociedades que observamos na contemporaneidade. Mas, ainda hoje, estes elementos são importantes para o resultado da guerra. Por exemplo, os tipos de armas que as forças armadas devem usar estão relacionados com os aspectos geográficos do território. Uma cavalaria, por exemplo, tem vantagens sobre a infantaria em um terreno plano e aberto. Já em terrenos montanhosos, ou florestas, a cavalaria perde seu potencial de mobilidade e a infantaria se torna mais eficiente.

O Coronel PAULA CIDADE que durante o governo do marechal Hermes da Fonseca em 1910 foi enviado junto com outros oficiais brasileiros a estagiar no Exército da Prússia, este grupo de pensadores militares, que foram estudar na escola alemã foram denominados de jovens turcos.

Pois uma das primeiras decisões do Marchal-presente foi justamente enviar uma missão à Alemanha, em 1910, com vistas a estes oficiais absorvem os ensinamentos desta nova matriz da modernização bélica, já em plenos preparativos para guerra mundial. Ao retornarem ao Brasil estes oficiais serão apelidados de "os Jovens Turcos", numa alusão irônica à sua admiração pelos revolucionários comandados por Kemal Aturk, que agitavam aquele país mulçumano desde 1908 (MARTIN, 2007:102).

Ao retornar participa da fundação da revista "A Defesa Nacional".

Foi um dos fundadores da Biblioteca do Exército. Autor de Notas de Geografia Militar Sul-americana de 1940, PAULA CIDADE, diz que a Geografia Militar se ocupa dos papeis que desempenham os elementos geográficos nas operações de guerra, papel essencialmente variável segundo as condições da luta, intensidades e da direção geral das operações. Esta definição posiciona a Geografia como algo que pode ser aplicado as condições da guerra em relação às operações militares. É um conceito que vai além das determinações geográfica do resultado de uma guerra. Neste conceito existe um embrião da geografia como uma ciência aplicada com um fim específico que é a confronto bélico, portanto colocando a geografia militar como instrumento usado para fins bélicos. 


\section{Geografia aplicada do Estado-Maior: A geografia militar}

Dois aspectos são fundamentais para percebermos o valor dos elementos geográficos na guerra: primeiro, o conhecimento dos fenômenos geográficos, tanto físicos como descritivos; segundo, a capacidade interpretativa para poder avaliar e interpretar a influência que teria nas operações militares que se projetam, permitindo, com isto, aproveitar, elucidar e vencer usando os aspectos geográficos. É desta capacidade interpretativa que se ocupa a geografia militar.

Seria um enorme erro considerar que os fatores geográficos significam tudo numa guerra, mas estes possuem uma grande influência, correspondendo aos profissionais das forças armadas determinarem seus verdadeiros valores. Muitas vezes o conselho da Geografia Militar só é levado em conta em parte pela estratégia e o apoiará suas manobras nos fatores negativos que apresenta o fator geográfico estudado.

Durante a Segunda Guerra Mundial, na frente russo-alemã, muitas operações se apoiaram em formas favoráveis, o inverso do que aconselhava os fatores geográficos. As mentiras da Alemanha atuavam no período de verão, já a antiga União Soviética apoiava suas operações no rigor do inverno; esta análise demonstra que o cenário geográfico era um dos fatores que influenciariam, de maneira mais ou menos imediata, a todas as concepções estratégicas com que ambos desafiantes pretendiam dar solução ao problema bélico. Alemanha queria vencer até o início do inverno, já os soviéticos pretendiam segurar os alemães até que o inverno começasse. 0 condutor militar deve aproveitar seu conhecimento geográfico do cenário de guerra para obter o maior rendimento das operações projetadas.

No entanto, seria um erro acreditar que os fatores geográficos sejam intransponíveis na preparação e condução da guerra; tal interpretação seria um grande erro. Uma concepção estratégica apoiada apenas nos fatores geográficos resulta numa análise inconsistente, pois a ação do cenário geográfico da guerra é relativa diante de outros elementos. Um exemplo que esclarece esta inconsistência vem, mais uma vez, da II Guerra Mundial: alguns anos antes da guerra, um estudo de Geografia Militar formulou algumas reflexões sobre a condução da guerra na fronteira alemã-luxemburguesa e na 
fronteira no extremo sudeste da Bélgica que inibe a movimentação entre França e Luxemburgo. A conclusão dos estudos franceses é que a região que se estende a parte francesa do pico de Meuse, e ambos os lados de Charleville, era muito desfavorável para as manobras de grandes unidades e da cavalaria pesada em função das dificuldades que o terreno; as montanhas de Eifel e os Ardenes e sua natureza pantanosa e de bosques.

Foi exatamente a partir desta região que em 10 de maio de 1940 o exército alemão superando as dificuldades naturais entra na França com pouquíssima resistência (ver figura 1). Temos que concordar que as dificuldades que oferecem esta região aos movimentos operativos de grandes unidades são extraordinariamente consideráveis deduz-se então que: primeiro que o comando alemão estava convencido de poder vencer as dificuldades e, segundo, que o comando francês confiando nestas dificuldades deveria ser surpreendido. "No dia 10 de maio iniciou-se a campanha alemã contra a França, com ataque contra a Holanda e a Bélgica; quatro dias depois, os blindados alemães rompiam as defesas francesas nas Ardenas" (MORTON, 2004:35).

"Plano de Ataque rápido à França" (Blitzkrieg)

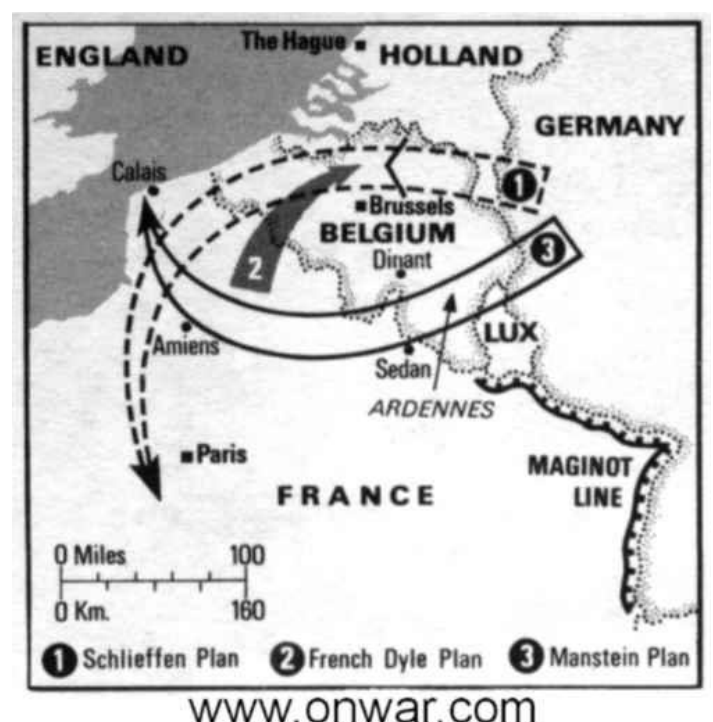

Figura 1- Blitzkrieg (in: www.onwar.com, acesso em 28/01/08) 
A presença de alguma interação entre as condições geográficas e os assuntos militares é o escopo da geografia militar. Segundo PELTIER \& PEARCY - em Military Geography, um manual sobre a geografia militar, publicado em Princeton (1966) - as pesquisas sobre o assunto se dividem em três grandes categorias: sistemática, geral e regional. A primeira categoria, a sistemática, direciona a aplicação da ciência aplicada para conduzir os assuntos militares. Já os amplos assuntos da geografia como a geomorfologia, hidrografia, biogeografia, geografia política que envolve a adaptação do soldado ao meio são exemplos da geografia geral. A geografia militar regional atua como síntese, trazendo vários aspectos da geografia e como eles devem ser aplicados a uma região militar particular. Embora todas estas considerações estejam presentes em comentários e estudos clássicos esta sistematização só foi possível no século XIX e XX, quando se desenvolve o ramo da fotografia, aerofotogrametria e a cartografia, então observamos um ritmo intenso em áreas mapeadas e um elevado grau de detalhe desse mapeamento.

A geografia é uma das ciências que compreendem um amplo campo de ação, abarcando conhecimentos específicos que vão desde entender nosso planeta no seu cosmo - o estudo da natureza e a constituição da Terra -, até observar a conduta do homem sobre a superfície terrestre. De maneira resumida, o caráter dual desta ciência consegue articular a relação entre o meio e a sociedade e como estes interagem. O meio pode ora ser um fator de barreira a determinadas manobras, ora pode ser superado através de uma tecnologia. Tanto no planejamento territorial quanto numa guerra as condições geográficas podem ser superadas com advento da engenharia. Mas o conhecimento geográfico é fundamental para prever as dificuldades e de quais materiais o exército irá precisar.

A geografia militar não é uma ciência separada da Geografia Geral. Ela foi muitas vezes classificada pela comunidade geográfica como geografia aplicada, segundo PELTIER \& PEARCY (1966). "No décimo nono Congresso Internacional de Geografia em Stockolm (1960) e no vigésimo Congresso Internacional de Geografia em Londres (1964) um novo ramo da geografia chamado geografia aplicada surgiu como distinto da geografia 
econômica"² (ibidem, 1966:19). Com a idéia de planejamento territorial que veio a ser uma das características essenciais dos Estados planificados o termo geografia aplicada passa a ter outra conotação. Os conhecimentos da geografia passariam a ter novas utilizações.

Devemos ressaltar que a geografia militar é uma disciplina que independe das ciências militares, por estar apoiada nos conhecimentos da Geografia Geral e Regional. Mas este conhecimento, por sua vez, está relacionado com a ciência militar, como já foi observado. Uma determinada especialização tem resultados positivos quando esta embasada em uma profunda e ampla cultura. Nenhum estudo necessita mais disto que a geografia militar, por seus problemas complexos e suas relações íntimas que mantém com o saber militar.

A geografia militar, segundo John M. Collins - em seu livro Military Geography: for Professional and The Public (1998) -, é um dos diversos segmentos do amplo campo da ciência geográfica. É o estudo da influencia do meio físico e cultural sobre as ações político-militares, planos, programas, e operações de combate e suporte de todos os tipos no mundo, regionalmente e no contexto local. Os fatores chave - aspectos físicos e culturais (ver tabela 1) - afetam o alcance de todas as atividades militares: estratégias, táticas, e doutrinas; comando, controle, e estruturas organizacionais; a otimização misturando a terra, o mar, o ar, e forças espaciais; escolha de um alvo; pesquisa e desenvolvimento; o fornecimento e alocação de armas, equipamentos e roupas; mais suprimentos, manutenção, construções, suporte médico e treinamento.

COLLINS (1998) afirma que a geografia militar nos Estados Unidos da América, somente começou a ser discutida no $92^{\circ}$ encontro anual da Associação de Geógrafos Americanos em 1996, após grande discussão para então se criar um grupo de estudo especialmente tratando do assunto. Antes disso, esta ramificação da Geografia era quase que desconhecida até mesmo pelas organizações de logística militar estadunidense.

\footnotetext{
${ }^{2}$ PELTIER \& PEARCY. Military Geography. At the Nineteenth Internacional Geographical Congress in Stockholm (1960) and Twentieth Internacional Geographical in London (1964), a new branch of geography called 'applied geography' emerged distinct from econmic geography". (p.19)
} 
A geografia militar serve de plataforma comum a todos os ramos do conhecimento militar ao analisar e conhecer o cenário de onde se vai atuar, recebe o aporte dos princípios e das leis que irão ser aplicadas num determinado cenário. A influência é recíproca e permite deduzir conclusões militares de um valor real. Podemos ressaltar as concepções estratégicas logísticas, orgânicas, entre outras, aplicando seus princípios à realidade geográfica se torna possível interpretar a influência militar do terreno numa determinada atividade bélica. Será uma questão para o comandante considerar e, ou, adotar o conselho que o terreno dá para uma operação militar que é projetada.

\section{Tabela 1- Fatores Geográficos}

\begin{tabular}{|l|l|}
\hline Aspectos Físicos & Aspectos Culturais \\
\hline Relação Espacial & Raízes étnicas e raciais \\
\hline Topografia e Drenagem & Padrão populacional \\
\hline Geologia e Solos & Estrutura Social \\
\hline Vegetação & Linguagens e Religiões \\
\hline Oceanos e Mares & Indústria e uso da terra \\
\hline Duração do dia e da noite & Rede de Transporte \\
\hline Gravidade e Magnetismo & Telecomunicações \\
\hline & Instalações Militares \\
\hline
\end{tabular}

Figura 2- Organizada por Filipe Giuseppe Dal Bo Ribeiro

\section{Geografia Militar X Geografia do Estado-Maior}

Para finalizar a discussão a cerca do conceito geografia militar cabe trazer para discussão o best seller da geografia civil: A geografia - isso serve em primeiro lugar para fazer a guerra de Yves Lacoste. Onde o autor diferencia de maneira bastante astuta a geografia dos professores ou geografia universitária e a geografia do Estado-Maior. Sendo a segunda muito mais antiga vinda de uma percepção empírica, ou seja, da prática, enquanto a primeira ao negar a segunda escamoteia o seu real propósito que é dar base para segunda. 
Para Lacoste a geografia do Estado-Maior se define da seguinte

maneira:

a geografia do Estado-Maior é um conjunto de representações cartográficas e de conhecimentos variados referentes ao espaço; esse saber sincrético é claramente percebido como eminentemente estratégico pelas minorias dirigentes que 0 utilizam como instrumento de poder. (LACOSTE, 2008:31)

E a geografia dos professores é, por sua vez:

A outra geografia, a dos professores que apareceu há menos de um século, se tornou um discurso ideológico no qual uma das funções inconscientes, é a de mascarar a importância estratégica dos raciocínios centrados no espaço. Não somente essa geografia dos professores é extirpada de práticas políticas e militares como de decisões econômicas (pois os professores nisso não têm participação), de poder que são as análises espaciais. Por causa disso a minoria no poder tem consciência de sua importância, é a única a utilizá-las em função dos próprios interesses e este monopólio do saber é bem mais eficaz porque a maioria não dá nenhuma atenção a uma disciplina que lhe parece tão perfeitamente "inútil". (LACOSTE, 2008:31)

Ainda é um grande tabu para a geografia pensar que 0 conhecimento geográfico esteja relacionado com a questão estratégica e militar. Não foi tarefa fácil para Yves Lacoste suportar as críticas vindas por parte de seus colegas quando lançou seu revolucionário livro: A geografia isso serve em primeiro lugar para se fazer a guerra em 1976. A pergunta que o professor Lacoste se propôs a responder com seu livro era: Pra que serve a geografia? Ora talvez esta não fosse a resposta mais adequada para momento em que ele escreveu esta contestada obra, pois com a iminente possibilidade de uma guerra nuclear a geografia estaria nadando contra todas as correntes científicas que estavam a pensar um mundo em que a guerra não poderia ser mais uma possibilidade e deveria ser de uma vez por toda completamente descartada. Mas se nos debruçarmos na resposta que é o título do livro e repensarmos a pergunta, acredito que o título faria mais sentido na época e, 
claro, hoje, se a questão formulada fosse a seguinte: em primeiro lugar pra que serviu a geografia? Essa pergunta seria menos contestada.

Cabe fazer uma análise destas proposições a cerca da geografia como ciência e elaborar uma crítica sobre os seus conceitos. Quando a geografia é colocada desta forma existe uma crítica severa sobre a produção científica da geografia, naquele momento, que ao se colocar neutra e acima de qualquer consciência sobre qual é a utilização real de seus paradigmas. Quando a geografia como ciência nega a existência do uso da geografia antes do surgimento desta como ciência, é a mesma coisa que negá-la em si mesma. E quando nos questionamos, para que serviu a geografia em primeiro lugar? Logo nos remetemos talvez a cinco séculos antes de Cristo, e encontramos Sun Tzu e sua Arte da Guerra, onde é realizado uma categorização do espaço para seu uso militar. A crítica de Lacoste, por outro lado, não analisa a questão de maneira pormenorizada, pois ao considerar que a geografia dos professores se proclama como ciência no século XIX, "os universitários de hoje consideram, todos, quaisquer que sejam suas tendências ideológicas, que a verdadeira geografia, só aparece no século XIX, com os trabalhos de Humboldt" (LACOSTE: 2008, 25). Esquece que mesmo Humboldt, mesmo sendo mais um naturalista que um geógrafo foi usado pelos Estados Unidos com propósito de conquista.

Lembremos que Humboldt foi proibido de entrar no Brasil, mas ao entrar no México mapeou informações nevrálgicas sobre os fortes e fortificações e quantos soldados e quais tipos de armamento existiam. Em visita pela América do Norte, Humboldt passou tais informações para nova república democrática da América, os Estados Unidos - que ele acreditava ser o farol da nova civilização - que utilizaram bem as informações conquistando todo o norte do México. Por sua vez o território brasileiro se manteve intacto de invasões externas.

O Presidente Jefferson ficou encantado com os mapas de Humboldt, o qual mandou ser compiado, e o barão tinha livre passagem na casa branca. Ao longo dos 20 anos seguintes Humboldt enviou para Jeferson copias do seus livros que Jeferson respondia com longas cartas, 
algumas vezes discutindo sobre o futuro da América Latina. (MCINTYRE, L, 1985) ${ }^{3}$

Outro ponto para ser considerado, foi a definição do conceito geografia do Estado-Maior. É apenas, outro nome que se dá ao conceito geografia militar. Lacoste não utiliza este termo, pois ele se remete ao século XIX e o referido autor tenta se desvencilhar, a todo custo deste momento que a ciência geográfica começa a se institucionalizar. Vale sublinhar o fato de que a ciência geográfica começa a ser estudada pelas escolas de oficiais do exército francês no início do século XIX, sendo os conhecimentos recém adquiridos utilizados na aplicação de técnicas e estratégias militares.

Segundo Philippe Boulanger (2005) ${ }^{4}$, na primeira metade do século XIX a disciplina Geografia Militar começa a ser ensinada na formação da elite militar francesa na Escola Especial de Saint-Cyr pelo professor Théophile Lavallée, que organiza os primeiros fundamentos desta disciplina em seu livro "Géographie physique, historique et militaire", publicado em 1832, reeditado em 1865 e em 1880. Depois da humilhante derrota francesa na guerra Franco-Alemã (1870-71) a Geografia passou a fazer parte definitiva da cultura militar. Portanto, podemos afirmar que Lavallée e sua Geografia Militar foram antecessores legítimos da Geografia Política e da Antropogeografia, ambas desenvolvidas por Ratzel na segunda metade do Século XIX, e da posterior Geopolítica de Kjellen.

Lavallée foi bastante influenciado pelo que havia ocorrido décadas antes da publicação da primeira edição de sua obra (op. cit., 1832): as guerras napoleônicas. $\mathrm{Na} 7^{\text {ạ }}$ edição em 1865 , ele revisa sua obra diante das guerras internas na França, Itália, Argélia e a Guerra da Criméia (1852), que possibilitaram novas análises no âmbito da Geografia Militar do continente Europeu. Também nesta edição, Lavallée reivindica sua autoria teórica na disciplina Geografia Militar chamando-a de "minha Geografia Militar".

\footnotetext{
${ }^{3}$ In: National Geographic, September 1985, Vol. 168, No. 3: "President Jefferson was delighted with Humboldt's maps, wich he sent to be copied, and the baron had free run of White House. During the next 20 years Humboldt sent Jefferson copies of his books an Jefferson responded with long letters, sometimes discussing the future of Latin America". (MCINTYRE, L, 1985) ${ }^{3}$

${ }^{4}$ In: www.stratisc.org - acesso 05/06/08.
} 
Eu o tenho modificado e corrigido inteiramente nesta $7^{\text {a }}$ edição; eu acrescentei à obra detalhes, que eu considero interessante, sobre as fronteiras da França, a Argélia, a Itália, a Criméia e etc. Finalmente, como minha geografia militar foi traduzida ou plagiada em várias línguas, eu consegui enriquecê-lo de informações que me foram trazidos de sábios oficiais estrangeiros: eu devo principalmente agradecer, a esse respeito, ao senhor Jackson, coronel da artilharia na armada britânica, quem publicou em Londres, em 1850, uma tradução inestimável de uma parte da minha obra sob o título de "A topografia militar do continente europeu do francês Sr. Th. Lavallée" ${ }^{5}$. (LAVALLE, 1865: prefácio) ${ }^{6}$

Portanto, para Lacoste era mais interessante o conceito colocado desta forma: geografia do Estado Maior, mais antiga, mas que como foi analisado apenas institucionalizado no século XIX, com o surgimento do conceito geografia militar. É bom lembrar que a própria geografia dos professores, aquela que foi institucionalizada e tem como grande fundador 0 naturalista alemão Humboldt, também, desenvolveu conhecimentos utilizados nas guerras de conquista no México pelos Estados Unidos. A conclusão desta questão é que tanto a geografia dos professores quanto a geografia do EstadoMaior tem a mesma origem e que a resposta de Lacoste esta se referindo a outra pergunta: Para que serviu a geografia em primeiro lugar? Ora esta serviu em primeiro lugar para se fazer a guerra. Hoje, diante da crise da civilização ocidental, anunciada como uma crise da humanidade, a pergunta a ser feita deve ser outra: A geografia - ou qualquer outra ciência - é imprescindível para se fazer a paz? Temos que ter a esperança de uma resposta afirmativa, mas não podemos ser ingênuos a ponto de acreditar nisto cegamente.

\footnotetext{
${ }^{5} \mathrm{Na}$ versão original: "The military topography of continental Europe of french Sr. Th. Lavallée".

${ }^{6}$ LAVALÉE, T. (1865: prefácio da $7^{\mathrm{a}}$ edição) "je l'ai entièrement remanié et corrigé dans cette 7 e édition; j'y ai ajouté des détails que je crois intéressant sur les frontières de la France, l'Algérie, l'Italie, la Crimée etc.; enfin, comme ma Geógrafie Militaire a eté traduite ou imitée dans plusieures langues, j'ai pu l'enrichir de renseignements que m'ont fournis de savants officiers étrangers: je dois principalement à ce sujet de remerciements à $\mathrm{M}$. Jackson, colonel d'artillerie dans l'armée britannique, qui a publié à Londres, en 1850, une traduction remarquable d'une partie de mon ouvrage sous le titre de "The military topography of continental Europe from the french of Th. Lavallée" (op. cit. 1865).
} 


\section{CAPÍTULO 2}

\section{GEOGRAFIA MILITAR E GEOPOLÍTICA: O CAMINHO DA IDEOLOGIA À ESTRATÉGIA E(OU) DA TÁTICA À PRÁTICA.}

Introdução

Existe uma discussão de extrema relevância no campo da Geografia Política acerca dos conceitos e uso das expressões: Geopolítica e Geoestratégia. O professor André Roberto Martin (2004) em sua tese inédita de livre docência - Brasil, Geopolítica e Poder Mundial - equaciona este problema da seguinte forma: "Geografia Política e Geoestratégia são os outros nomes que se da à Geopolítica" (MARTIN, 2004: 8). Os detalhes desta discussão estão muito bem exemplificados e analisados nesta tese, portanto este tema não será aprofundado nesta discussão. Mas o tema que aborda as definições sobre as distinções da Geografia Política e Geopolítica foi levantado pelo professor Wanderley Messias da Costa (1992) em sua tese - Geografia Política e Geopolítica: discurso sobre o território e o poder - este último, por sua vez, afirma que a geopolítica é "antes de tudo um subproduto e um reducionismo técnico e pragmático da geografia política" (COSTA, 1992: 35). Ambos, de maneira diferente, atrelam os conceitos Geografia Política e Geopolítica.

Cabe aqui diferenciar e ressaltar a diferença entre dois conceitos que estão diretamente relacionados com esta discussão: das diferenças e relações entre geografia militar e geopolítica - estratégia e tática - e como elas se complementam e se relacionam, pois certamente a tática não é estratégia, assim como a geografia militar não é geopolítica, mas a tática esta para estratégia, assim como a geografia militar esta para geopolítica.

A estratégia é vista pelas ciências militares como a arte e a ciência do desenvolvimento e empenho das forças políticas, econômicas, psicológicas e militares de uma nação, tanto na paz como na guerra, para prestar o máximo de apoio aos desígnios das ações nacionais, para incrementar as possibilidades e conseqüências favoráveis da vitória ou de reduzir os efeitos de uma derrota. De acordo com B.H. Liddel Hart: "o papel da grande estratégia - alta estratégia - é coordenar e dirigir todos os recursos de uma nação, ou um conjunto de nações, em razão de conquistar os objetivos 
políticos da guerra - a meta é definida fundamentalmente pela política" (HART, 1954 apud PELTIER \& PEARCY,1966: 32) ${ }^{7}$. Segundo MARTIN (opt.cit.,2004), a dimensão militar do poder nacional e mundial trouxe para discussão a noção do conceito de estratégia. Sobre a origem da palavra temos:

Esta palavra surgiu em Atenas, uma potência marítima, que durante o chamado "século de Péricles" tinha por hábito eleger e destituir seus chefes militares em praça pública. Assim cabia ao "strategos autocrator" justificar suas atitudes diante da Assembléia popular (...) Também em Roma existiu a mesma prática, só que o "strategos" passou a ser chamado de "dictator" (MARTIN, 2004: 12)

No clássico Da Guerra (Vom Krieg) de Carl von Clausewitz temos uma discussão sobre a teoria da guerra e sobre o que para ele significava o conceito de estratégia. Podemos extrair que a estratégia esta relacionada com os planos, objetivos, ações; que não necessariamente serão concretizados, mas irão balizar o confronto de maneira geral. Clausewitz reconheceu cinco elementos da estratégia, expressos como: elementos psicológicos, incluindo a questão da moral; a força militar, incluindo seu tamanho, composição e organização; a geometria da situação, incluindo as posições relativas ao movimento das forças, os obstáculos, canais de ação, objetivos e etc; terreno, incluindo montanha, rios, florestas e estradas, que pode influenciar as atividades militares; apoio, incluindo o meio e as fontes. A estratégia ao encontrar dificuldades no campo de batalha deve recorrer ao apoio tático da Geografia Militar que através das condições momentâneas pode fazer valer os planos idealizados pela estratégia. No Livro III - Da estratégia em geral temos:

A estratégia (...) tem uma finalidade para o conjunto do ato de guerra que corresponda ao objetivo da guerra. Quer dizer: estabelece o plano de guerra determina em função do objetivo em questão uma série de ações que a ele conduzem; elabora portanto os planos das diferentes campanhas e organiza os diferentes recontros destas ações. Dado que todas essas decisões em grande parte só poderão assentar em suposições que nem sempre se realizam, e que um grande número de outras disposições

\footnotetext{
${ }^{7}$ Hart, B. H. Liddell, Strategy (Frederick A. Praeger, Inc, New York, 1954), pp.335-36. "the role of grand strategy - higher strategy - is to coordinate and direct all the resource of nation, or band of nations, or band of nations, toward the attainment of political objective of war - the goal defined by fundamental policy".
} 
mais detalhadas não podem ser tomadas antecipadamente, resulta que a estratégia tem de acompanhar o exército no campo de batalha para que, no próprio local, se tomem as disposições de detalhe necessária e se proceda às modificações gerais que se impõem incessantemente. (CLAUSEWITZ, 2003:171)

\section{Geoestratégia e Geografia Estratégia, ou Geopolítica e Geografia Militar}

O general francês, André Beaufre sintetizou bem o conceito de estratégia: "Estratégia é a dialética de vontades antagônicas" (BEAUFRE, 1964:9 apud MARTIN, 2004:12). O geógrafo norte-americano, George Crassey (1951), define estratégia como: "Estratégia é a aplicação da política; refere-se tanto em tempos de paz, a questão de cooperação cultural, quanto à questão de equilíbrio de forças em tempos de guerra" (CRASSEY, 1951 apud MARTIN, 2004: 13). CRASSEY (1951) propõe o conceito Geoestratégia para substituir e por fim a polêmica sobre os conceitos de Geografia Política e Geopolítica, por ser um conceito mais amplo "a Geografia possui um leque mais amplo do que a Política, e desse modo, conviria utilizar um termo que pudesse dar conta de todo um leque de relações comerciais e culturais, internas e externas" (MARTIN, 2004:13). Sobre o conceito de Geoestratégia:

devemos reconhecer três características que identificam
este conceito, para fins de sua utilização política; sua
origem militar, a necessária presença de antagonismos
e, portanto, a possibilidade de luta e, além disso,
notadamente, à política mundial (...) a do ajuste entre os
meios e fins, e da antecipação dos movimento do
inimigo. Finalmente, vale anotar que Ferndinand Braudel
(...) fez uso das noções de Geohistória e Geoestratégia
relacionando a primeira ao estudo das paisagens
pretéritas e a segunda às prospecções em torno da
organização do espaço a ser produzido. (MARTIN,
$2004: 13$ )

Podemos apreender do conceito de estratégia duas premissas: a primeira que a Estratégia concebe e direciona a guerra num plano mais alto; e a segunda, coordena a totalidade das forças e dos recursos nacionais tanto na preparação como na execução do conflito, ou para evitar o conflito através de alianças. Para estes termos, se faz necessário um planejamento, a base de uma análise político-estratégica e estratégica, e a geografia aparece como um 
dos elementos de apreciação - no caso a geografia militar - entregando ao chefe do Estado Maior as conclusões que os estudos dos fatores geográficos proporcionam do ponto de vista bélico.

Se a geoestratégia é o outro nome que se dá à geopolítica, a geografia estratégica é outro nome que se dá para geografia militar. Segundo PELTIER \& PEARCY,1966, a geografia estratégica se encaminha para o plano da geografia da guerra, plano da campanha da guerra e o plano operacional da guerra. Entretanto a geografia estratégica também deve envolver 0 desenvolvimento de modelos realistas e padrões de treinamento. Dos cinco elementos da estratégia expressados por Clausewitz, a geografia estratégica esta associada com a geometria das operações, com o meio da área de operações, e os apoios dos meios e fontes de recursos. Porque a geografia estratégica é a geografia dos planos, e isto deve ser um prognóstico dos estudos de procedimentos, como uma prévia do que se pode imaginar sobre as atividades militares sobre condições específicas. Este conjunto de condições especiais provê um elemento de motivação pelo qual se desenvolve os aspectos dinâmicos da geografia. Isto, também, provê uma fonte de relações e estudos dos impactos das ações militares, seus custos e sua eficiência.

Os princípios da geografia estratégica envolvem a interpretação de informações básicas para o uso na preparação de planos para conduzir a guerra, ou para as operações durante a guerra. Dentro deste contexto as grandes considerações da geografia estratégica devem ser descritas em seis elementos: acessibilidade, mobilidade, visibilidade, comunicabilidade, disponibilidade e vulnerabilidade. Segundo PELTIER \& PEARCY (1966), esses elementos inclinam-se para centralização do fator da acessibilidade num sentido amplo do mundo. Mais especificamente esses elementos relacionam a interação entre as forças ou componentes, e se esse contato pode ser visual, eletrônico ou direto; se esse contato com os tipos de armas que serão usadas é plausível de importância, tanto numa ação ofensiva quanto defensiva.

Os exércitos da era pré-elétrica operavam em um horizonte de inteligência consideravelmente menor que 160 quilômetros. Daí a enorme importância atribuída pelos comandantes do passado à informação estratégica; o tipo de inimigo, o tamanho e a capacidade de suas forças, sua disposição, a natureza do terreno em 
sua zona de atividade e, mais geralmente, os recursos humanos e naturais dos quais dependia sua organização. (KEEGAN, 2006:37).

A acessibilidade, a primeira dos seis elementos da geografia estratégica sobre discussão, refere-se ao sentido físico do termo e, também, isto inclui condições das construções, organização espacial da população, tipos de estradas, rotas, distâncias. Entretanto, a acessibilidade se difere para o uso de carros de combate (automóveis), aviões e barcos. Os aviões têm uma velocidade elevada, mas precisam de uma pista de pouso. A acessibilidade da pista de pouso é bem diferente da acessibilidade da área de manobra entre dois aeroportos e entre a área de ação que possuem uma dependência, por sua vez, do tempo atmosférico. Os automóveis, caminhões, carros de combates viajam bem em áreas limpas, planas e superfícies planas, mas não são eficientes em áreas de pantanosas e florestas. Os navios são importantes componentes, pois carregam consigo, os aviões, caminhões, batalhões, mas precisam de uma área para aportar e despejar as forças no território inimigo.

Um bom exemplo recente sobre a questão da acessibilidade é a Guerra do Iraque. Ora este país tem certas facilidades em relação a sua acessibilidade, pois a sua entrada pelo Golfo Pérsico é favorável ao desembarque pelo Kwait, país aliado dos Estados Unidos, e seu relevo é marcado pelas planícies do Tigre e Eufrates, favorecendo a mobilidade de tanques pesados. A população é concentrada na região da capital Bagdá. Todos esses elementos favorecem uma guerra de conquista. Já o Irã não apresenta boas condições de acessibilidade. O desembarque pelo Golfo Pérsico não é tão fácil, pois os portos são bem protegidos pela marinha iraniana e o difícil acesso favorece a defesa. As cadeias montanhosas do Platô Iraniano dificultam acessibilidade para os carros, a população bem distribuída pelo território dificulta uma guerra de conquista. A atual tese do governo americano é ampliar os esforços de guerra no Afeganistão que possui uma posição central e dá mais acessibilidade ao Irã, do que as áreas de planícies do Iraque, por ser mais alto e ter mais centralidade aos interesses atuais dos Estados Unidos, as forças estadunidenses podem pressionar tanto o Irã quanto Paquistão e estarão numa altitude maior do que ambos, fazendo do Afeganistão uma base ideal para 
movimentações de suas infantarias treinadas para operações em montanhas e cavernas.

Os acidentes geográficos não são imperativos para prescindir a realização de uma empreitada estratégica e nem poderiam ser; estes, simplesmente, facilitam ou dificultam as operações. Não acreditar nisto seria engendrar um conceito hipertrofiado das questões geográficas e criar um determinismo unilateral com a natureza mesma da guerra. Um general ou um chefe do Estado Maior, quando habituado a uma interpretação correta dos acidentes geográficos sabe que: vencer o acidente geográfico quando a manobra o impõe; evitar o acidente geográfico quando o tempo e o espaço permitam; e por fim, utilizar o acidente geográfico com fins relativos à economia e as forças armadas.

A mobilidade envolve a habilidade de se movimentar como um todo. Isto inclui a velocidade das unidades, a liberdade de escolher o sistema de transporte, o fluído do tráfego e engarrafamentos, os efeitos sazonais do clima, e a existência rotas prontas e facilidades terminais. Como uma expressão de capacidade e flexibilidade no movimento, a mobilidade não depende apenas da direção do movimento, mas também, do que deve ser movimentado e da organização deste movimento. Então as armas pesadas são menos móveis do que as armas leves, equipamentos autopropulsado são mais móveis do que equipamentos rebocados, e tropas organizadas são mais móveis que civis refugiados desorganizados. Um bom exemplo da questão da mobilidade vem da Guerra de Secessão Americana. "A fotografia, o telegrafo, os foguetes de sinalização, os balões de observação e os trens tiveram sua estréia como artefatos de uso militar na Guerra de Secessão" (MARTIN, 2006:246). A descrição da dificuldade de mobilizar um grande exército era enorme:

Para se ter uma idéia mais precisa dos volumes mobilizados, considere-se que um exército de $100 \mathrm{mil}$ homens consumia mais de 600 toneladas de suprimentos por dia, o que exigia 2,5 mil carroças e 35 mil animais de tração, os quais também precisavam ser alimentados. Cada grupo de 80 carroças, carregando munições e víveres, e contando com algumas ambulâncias, cobria $1 \mathrm{~km}$ de extensão, de modo que 0 
abastecimento do exército de 100 mil homens exigia uma fila de carroças de $30 \mathrm{~km}$. (MARTIN, 2006:246).

A visibilidade abarca o campo de visão horizontal e vertical, ou do sensoriamento. Antes da era pré-eletrônica a visibilidade tinha uma importância grande na inteligência das forças armadas. Depois com a invenção do telegrafo elétrico na metade do século XIX e com a sua substituição pelo rádio a comunicação passou a ser mais importante do que a visibilidade, ainda hoje do ponto de vista tático a comunicação via rádio é importante, pois seu resultado é imediato no campo de batalha. Antes mesmo das tão comentadas imagens de satélite as fotografias áreas já eram usadas em balões, em 1849, o Coronel Aimé Laussedat, um oficial do exército francês, utilizou um sistema fotográfico desenvolvido por Daguerre embarcado em um balão para obter fotos cuja finalidade era o mapeamento topográfico. As fotografias aéreas e os balões foram intensamente usados da Guerra de Secessão Americana e mais tarde na Primeira Grande Guerra Mundial. Mas, atualmente, as imagens de satélite com definição de até um metro são imbatíveis no que diz respeito à visibilidade, podendo acertar com precisão a quilômetros de distância. "A visão é, naturalmente, o meio principal e mais imediato de obter inteligência em tempo real. Era assim na era pré-telegráfica e voltou a ser assim na era da imagem visual eletrônica" (KEEGAN, 2006:37).

Comunicabilidade significa a habilidade para transmitir informação. Isto inclui os efeitos do tempo atmosféricos, tempestades magnéticas, aspectos do território, existência sobre desenvolvimento cultural, facilidades de construção, eficiência operacional e manutenção dos sistemas de comunicação. Os aspectos geográficos estão relacionados a condições em lugares específicos que podem mudar ou influenciar os sistemas de comunicações. Como, por exemplo, numa população esparsa com pouca infraestrutura são menos apropriadas para comunicação do que as áreas urbanas. A comunicação geralmente acompanha as linhas de estradas de ferro e rodovias, até a comunicação via satélite, depois deste evento é possível coordenar operações dos Estados Unidos em lugares tão distantes quanto 0 Oriente Médio, ou até mesmo na Lua se preferir. Em alguns lugares como montanhas e florestas podem atrapalhar a transmissão de comunicação e 
restringir a eficiência do comando favorecendo a descentralização das atividades militares.

Disponibilidade é uma palavra de uso comum, mas neste caso é aplicada a estratégia. Este conceito aparece em importância não apenas por expressar a existência de soldados, equipamento e suprimentos, mas também, por sua presença estar no lugar certo, na hora certa e na quantidade adequada. Então, segundo PELTIER \& PEARCY (1966), a disponibilidade não expressa somente à existência, mas a quantidade e a localização. Na Segunda Guerra Mundial o petróleo que abastecia a Itália não era disponível as suas forças no Norte da África e a fabricação da munição dos aliados produzida no continente americano teve que estar disponível para Inglaterra, Rússia, China e áreas no Norte da África. Portanto, a disponibilidade reflete o efetivo, suprimentos, transporte, pré-posicionamento, e outros aspectos de suporte material. Isto reflete as características do grau de desenvolvimento, da organização destas importantes funções e para suporte da organização militar. Vulnerabilidade, o último dos seis elementos da geografia estratégica, difere dos outros elementos no que ele expressa, neste o que importa não é o que alguém pode fazer, mas sim o que pode ser feito por alguém. Este expressa 0 produto acabado, finalizado, ou seja, a capacidade de acesso do inimigo, o movimento e a disponibilidade. Inclui-se a necessidade das pessoas, facilidades da produção, instalações militares e as rotas de transporte para proteção. Também, os aspectos psicossociais como: o estado de bem-estar, subsistência da população, moradia, infra-estrutura pública, lazer, e outras necessidades que mantêm a moral e a lealdade da população ao Estado; estão inclusos no aspecto da vulnerabilidade. Finalmente, este elemento, inclui não somente a precisão das forças militares estarem prontas para um ataque direto, mas, também, estarem protegidas contra a propaganda, a sabotagem e outras coisas desta natureza.

Logo existe uma profunda relação entre a estratégia e a geografia militar; sua influência se faz sentir tanto no planejamento como na condução das operações militares.

Sobre o conceito de tática o dicionário HOUAISS diz: 
1- arte da Guerra que trata de como proceder durante um combate ou batalha; 2- Arte de dispor e manobrar as tropas no campo de Batalha para conseguir o máximo de eficácia durante um combate.

Percebe-se que a geografia militar está relacionada com a condução das operações militares. Por outro lado, a Geopolítica está mais relacionada às estratégias, por ser mais ideológica do que prática, "temos que a Geografia Política surgiu desde logo como ideológica e como ciência, carregando esta contradição original até o presente" (MARTIN, 2004: 12). A geografia militar é definida por ser a geografia aplicada do Estado Maior, é a prática, que viabiliza a estratégia.

Em uma tradução comentada sobre o livro $A$ arte da Guerra de Sun Tzu, Ralph D. Sawyer - consultor de companhias americanas para o comércio com extremo oriente e responsável por algumas versões definitivas de antigos textos militares chineses - comenta que acerca da questão da tática:

as táticas militares, por se fundarem sobre antecedentes históricos, serem formuladas em termos de conceitos contemporâneos, se centrarem em capacidades reconhecidas e se dirigirem para realização de objetivos políticos, são inevitavelmente produto de ambientes específicos (SAWYER, 2006:10)

Existe outro conceito sugerido por PELTIER \& PEARCY (1966), a geografia tática que se distingue da tática, pois tática significa o emprego das unidades de combate no modo de como elas se organizam, se postam e manobram podendo trazer o máximo da efetividade e a vitória militar. Enquanto, a geografia tática é a geografia do campo de batalha e envolve os fatores geográficos da batalha em si. Ela inclui a geometria da disposição das unidades, sua velocidade e direção de seus movimentos, 0 apoio do movimento, circulação do transporte, e o ambiente físico e psicológico do campo de batalha. De fato, a geografia tática serve para inúmeras atividades associadas com a corrida geral das operações de combate: a geografia das manobras, dos acampamentos e quartéis, da cobertura e dos esconderijos, das fortificações, e outras estruturas militares organizadas num território. O último objetivo da geografia tática depende de todas essas relações entre a missão e 
o ambiente que são úteis no treinamento e na formulação da decisão do comando. A essência da geografia tática repousa na avaliação do espaço e dos fatores do ambiente cuja influencia na movimentação, no uso e tipo de armas e na estimativa das chances que alguém ou um grupo específico desses fatores irão ser importantes no tempo e lugar certos.

\section{Geografia Militar e a organicidade da logística}

A logística, antes de qualquer coisa, deve se pautar no espaço concreto, ou território, por mais que as novas tecnologias diminuam as distâncias de maneira significativa, ainda é necessário abastecer de suprimentos, armas, munições, as forças em combate, e todo este material chega ao teatro da guerra percorrendo um espaço, mesmo na era do ciberespaço, é impossível fazer isto - até que uma nova tecnologia apareça sem percorrermos o território não é possível pensarmos na organização logística, com exceção da comunicação, que pode ser feita via satélite, e é por possuir uma conotação material que, a logística, deve estar pautada em sua determinada territorialidade, por isso, ainda hoje, o estudo de geografia militar carrega inestimável importância.

Em Da Guerra, Clausewitz afirma que o exército pode encontrarse em três situações diferentes: aquartelado, em marcha, ou acantonado. $\mathrm{Na}$ ausência de qualquer objetivo, o único que deve contar é o da subsistência, conseqüentemente, a segurança do exército. Aplicada a segurança e existência do exército é importante a reflexão dos seguintes pontos: facilidade de abastecimento, facilidade de abrigo para tropas, segurança das retaguardas, espaço livre na sua frente, estabelecimento da sua posição em si em terreno recortado, pontos de apoio estratégicos e repartição apropriada das tropas. Até os dias atuais, os conselhos do velho Clausewitz não devem ser descartados de maneira alguma.

O exército alimenta-se essencialmente sobre o território onde está estacionado, todavia forma um todo com sua base. As linhas de comunicações pertencem a esse todo; elas ligam a base ao exército e devem ser consideradas como outras tantas artérias vitais. As entregas de toda espécie, os transportes de munições, 
os destacamentos que vão e vêm, as estações do correio e as correspondências, os hospitais e os depósitos, as reservas de munições, as autoridades administrativas, todos esses serviços circulam incessantemente nessas estradas e o seu valor global é de importância decisiva para o exército. (CLAUSEWITZ, 2003:447).

Esta análise deve ser contemplada ainda hoje. Observando os avanços tecnológicos importantes que alteraram os rumos da guerra, ainda hoje estas proposições, com exceção das linhas de comunicação, são relevantes na construção de uma estratégia, portanto mesmo com o mundo virtual e com a chamada guerra nas estrelas, não é possível fugir destas questões: transporte de munições, os hospitais, depósitos, circulação das autoridades e etc. Não se faz isso no espaço virtual e nem via satélite, é necessário, pois, fazê-lo diante das condições do território.

No final do século XIX, o debate havia evoluído para possibilidade da disputa do poder mundial em dimensões realmente globais. A grande questão que se debatia eram os jogos de poder e das relações entre as potências. Até o início do século XX, o poder esteve em torno da esfera do "poder marítimo" versus a esfera do "poder terrestre" e esta questão está relacionada de maneira intrínseca com a logística e a organicidade da guerra de forma impactante. As principais teorias geopolíticas do fim do século XIX e século XX debateram esta questão de forma calorosa. Não obstante, algumas possibilidades trazidas pela geografia militar nas análises destas "ideologias geográficas" (ROBERT MORAIS) são de suma importância para este debate.

Friedrich Ratzel, o primeiro a desenvolver os conceitos da Geografia Política (opt. cit. 1897) percebeu que o "poder mundial" era resultado da disputa entre potências "marítimas" e "continentais". Ratzel acreditava que se um Estado conseguisse ter maior mobilidade espacial, ou seja, dominar os mares e a partir disto ter acesso a áreas férteis e aos recursos naturais ou a partir de estepes inférteis se mobilizasse em uma expansão territorial este teria maiores vantagens na disputa do poder mundial, enquanto o estado que se limitasse ao lugar de origem estaria fadado ao fracasso, embora fosse muito importante para uma nação a identificação com sua terra natal. No contexto em que estão inseridos estes preceitos a Inglaterra cuja mobilidade marítima 
resultou no domínio das principais áreas férteis e recursos naturais do planeta (A foz dos rios Níger, Congo, Zambeze, Orange, Nilo, Indu, Ganges, diamantes no Orange entre outras possessões), e a Rússia que teve sua mobilização a partir das estepes e conquistou um território de dimensões continentais onde possuía recursos quase que inesgotáveis diante de sua grandeza territorial ${ }^{8}$.

Por isso, a formação de Estados impele dos mares e estepes (lugares de movimento) para florestas e terras aráveis (lugares de permanência). Um estabelecimento permanente leva ao enfraquecimento e à decadência, enquanto que a mobilidade, por outro lado, promove a organização de populações (RATZEL apud ROBERT MORAES, 1990, p.190).

O almirante americano, Alfred Thayer Mahan, em seu livro The influence of Seapower upon the French Revolution and Empire, 1793-1812, publicado em 1892, registra como o poder naval conseguiu ser mais efetivo do que o poder terrestre no confronto entre o Império Britânico e o Império Napoleônico, principalmente no episódio da Batalha de Trafalgar onde o almirante Nelson ${ }^{9}$ conseguiu destruir quase que completamente a frota napoleônica. Efetivamente, até os meados do século XIX, o poder naval tinha uma maior mobilidade e força enquanto o poder terrestre tinha dificuldades de movimento que eram essenciais para uma vitória completa. A Inglaterra simplesmente reduziu a França ao continente e sua grande mobilidade possibilitou a comercialização com todos os portos longe do poderio francês, mesmo, durante o Bloqueio Continental. "A Grã Bretanha se havia estabelecido na Índia, mas para ir de Roma a Paris, Napoleão levava mais ou menos o mesmo tempo que César". (ARON, 1962, p.155). E mais tarde em 1852 a Inglaterra mediu forças, mesmo que indiretamente, com o gigante Império Russo na Guerra da Criméia e mais uma vez o poder marítimo se mostrou

\footnotetext{
${ }^{8}$ MARTIN, A. R. - Geopolítica e poder mundial - "a sua (Ratzel) conclusão de que só o poder marítimo conduz ao verdadeiro poder mundial, uma vez que a massa líquida dos oceanos contém a massa sólida dos continentes, e estes últimos estão separados entre si, ao passo que os oceanos estão interligados".

9 MONDAINI, M. - Guerras Napoleônicas. em: História das Guerras. -“o sonho napoleônico de desembarcar seu Grande Exército em Londres desapareceu para sempre depois da arrasadora vitória inglesa na Batalha de Trafalgar, em 20 de outubro de 1805. Sob o comando do lendário almirante Nelson, 27 navios ingleses dispostos de maneira inovadora em colunas, e não na tradicional formação em fila, destruíram 18 embarcações francesas e 15 espanholas comandadas pelo almirante Villeneuve”. (p.205)
} 
mais eficiente, bloqueando a saída pelo estreito de Dardanelos ao Mediterrâneo.

A transformação que ocorrera na Europa a partir dos meados do século XIX, talvez, colocaria a questão da supremacia do poder marítimo em dúvida, pois a revolução no transporte por terra, isto é, o transporte ferroviário, que ao se expandir ligou áreas que até então só eram possíveis ao acesso rápido pela via marítima. "Em 1850, havia menos de 24 mil milhas de trilhos ferroviários instalados pelo mundo, número que seria quase dez vezes superior em 1880, quando chegaram as 230 mil milhas". (MARTIN, 2006, p.222). Foi a Segunda Revolução Industrial que com advento do aço, do motor a combustão interna em 1871, e da eletricidade que transformaram as relações do transporte terrestre em relação ao transporte marítimo. As "Inovações Tecnológicas" a partir de meados do século XIX modificaram muito a maneira de pensar 0 mundo. Em 1869, temos um ano histórico para engenharia mundial "em 9 de maio, os trilhos da Central Pacific e da União Pacific encontram-se no Utah, completando assim a ligação ferroviária entre o Atlântico e o Pacífico" (Ibidem, 2006, p.222).

Segundo FOSSATI (1974), a Guerra da Criméia havia debilitado muito os cofres russos que viram na venda do Alasca para os Estados Unidos, em 1867, uma possibilidade de equilibrar as reservas do Império. Então o Czar Alexandre II e posteriormente seu filho, um pouco mais que duas décadas, iriam desenvolver a maior via terrestre já construída até então, à Transsiberiana, que começaria, em 1891, a ser construída e ligaria até o final de 1916, Moscou à Vladivostock, com uma extensão de 9.289 km, abrangendo 8 fusos horários e ligando o território do maior Império terrestre da história da humanidade trazendo uma possibilidade real de saída para o mar do Japão e compensando a perda territorial do Alasca.

A Guerra Russo-japonesa (1905 e 1906) seria travada, mais uma vez, a disputa entre uma potência terrestre, o Império Russo, e uma potência marítima, o Império Japonês. Pela primeira vez uma potência européia disputaria uma área de influência com uma potência fora do sistema europeu do poder mundial, e as conseqüências seriam negativas para o Império Czarista que além de ter empreendido muitos recursos, tanto na construção da épica Transsiberiana quanto no esforço de guerra - principalmente com sua 
marinha que se rebelando contra o regime czarista em meio ao confronto contra os japoneses no episódio do Encouraçado Poutankim - não conseguiu conquistar a Coréia e muito menos a Manchúria, ou seja, suas possíveis saídas para águas navegáveis no mar do Japão em mais uma frustrante tentativa.

Com França e Rússia reduzidas depois de desastrosas tentativas de se tornarem uma potência "anfíbia", os Ingleses não contavam com aparecimento de outra potência terrestre que levaria o desequilíbrio ao sistema internacional e, consequentemente ao fim da pax-britânica, a Prússia ou Império Germânico. Este novo Estado que através de rápidas guerras de unificação, como: a guerra Austro-prussiana (1866) que colocaria o poderoso Império Austríaco em posição menor frente à Prússia; a guerra Francoprussiana(1870-71) que submeteria a França frente à Prússia. Além da supremacia militar, também, realizou uma via de desenvolvimento industrial rápida e no final do século XIX, possuindo uma indústria siderúrgica mais forte, um exército mais poderoso e uma população superior que a do Império Britânico e com a possibilidade da construção de uma estrada de ferro que ligaria Berlim-Istambul-Bagdá colocaria em xeque a mobilidade do poder marítimo frente ao poder terrestre. Diante deste estrondoso aparecimento, o Império Germânico convocaria a Conferência de Berlim de 1884-85 visto que diante dos novos espaços coloniais, só haviam sobrado apenas os desertos e os pântanos a Alemanha, nas palavras do próprio "chanceler de ferro" Bismarck, colocando a Alemanha não só uma potência continental, mas reivindicando, principalmente, um lugar como potencia colonial, além mares, ou seja, uma potência anfíbia.

Clausewitz, Ratzel, Mahan entre outros, viveram tempos de grande transformações, mas a guerra só vai tomar proporções globais no século XX. Depois do grande desenvolvimento do transporte terrestre e das linhas de comunicação - o trem, motor a explosão e o telegrafo - que modificaram as bases do pensamento estratégico, e, por conseqüência, do pensamento geoestratégico/geopolítico; e claro do pensamento de como pensar a geografia militar diante deste novo contexto. Com a invenção do avião e do desenvolvimento da balística, que os paradigmas das teorias se transformariam diante das novas maneiras de se apropriar o território, da consolidação do Estado-Nação, das Guerras Mundiais, da descolonização e 
toda a concepção da geopolítica mundial se modernizará completamente, conseqüentemente a geografia militar acompanhará estas mudanças. Este debate será vivido na oposição teórica entre a teoria do Heartland e do Rimland, que certa forma são o desdobramento dos debates vividos no século XIX.

\section{A Geopolítica como ideologia e a geografia militar como prática}

Duas significativas ideologias geopolíticas: a teoria do Heartland a tese; e o Rimland - a antítese. Ao que parecem, são bastante elucidativas para se entender como a Geopolítica e a Geografia Militar serão pensadas do século XX e como uma influencia a outra.

Na conferência pronunciada diante da Real Sociedade Geográfica de Londres em 25 de janeiro de 1904 e reproduzida no The Geographical Journal, volume XXIII, o geógrafo Halford J. Mackinder expôs sua revolucionária tese do Pivot Geográfico da História em que dizia que a era Colombiana que durante quatro séculos havia dominado a cena das relações político-econômicas com o seu colonialismo e neo-colonialismo chegara ao seu fim no início do século $X X$, pois com todas as transformações nos transportes terrestres, dinamizando a mobilidade por terra, e com a impossibilidade do poder marítimo acessar o Heartland, - o interior da Ásia correspondente as estepes da Mongólia e da Sibéria de onde hordas bárbaras, hunos e mongóis, por exemplo, impulsionadas como uma mola, pressionaram ao longo da história as terras que a cercavam, o arco externo da Eurásia representado pela Europa, Oriente Médio, Índia, e China ${ }^{10}$ - o domínio do poder marítimo, ou seja,

\footnotetext{
${ }^{10}$ MACKINDER, H. J. - El pivot Geografico de la História: “ Lãs hordas en el último término cayeron sobre Europa, a mediados del siglo XIV, reunindo sus fuerzas a unos 4.500 kilómetros de distancia, en las altas estepes de Mogolia. Los estragos causados durante algunos años en Polonia, Silesia, Moravia, Hungria, Croacia y Servia no eran, sin enbargo, sino el resultado de los nómadas del este que estaban asociados al nombre de Gengis Khan. Mientiras la horda dorada ocupaba la estepa de Kipchak, desde el Mar Aral, a través del espacio que hay entre los Montes Urales y el Mar Caspio, hasta el pie de los Cárpatos, outra horda descendió hacia el sur entre el Mar Caspio y Hindu Kush, penetró em el Irán y la Meseopotamia, y llegó a Síria fundando el dominio del llkan. Una tercera penetró en la China septentrional, conquistando Catay. La Índia y Mangi, o sea la China meridional, fueron protegidas durante algún tiempo por la imcomparable barrera del Tibet, cuya eficácia como tal quinzás no tenga igual em el mundo, a non ser el desierto de Sahara y los hielos polares. Pero posteriormente en los dias de Marco Pólo en caso de Mangi, y en los de Tamerlán en el de la India , el obstáculo fue rebasado. Deste modo fue como todos los bordes del Viejo Mundo llegaron a experimentar, antes o depués, la fuerza expansiva del poder móvil originado em la estepa. Rusia, el Irán, la India y la China fueron convertidos en tributarios o recibieron dinastías mogoles. Hasta el incipiente poder de los turcos em el Ásia Menor se vio durante médio siglo.
} 
a era Colombiana chegava ao seu término, com a iminente vitória do poder terrestre que dominasse a região de maior importância geoestratégica do mundo, o Pivô Geográfico da História ou o Heartland. A primazia desta região é justamente estar em uma posição protegida de qualquer ação do poder marítimo, ao mesmo tempo, que faz fronteira com as áreas mais populosas do planeta.

Portanto, para Mackinder, quem dominasse o Heartland, poderia influenciar toda a Eurásia e quem dominasse esta "ilha mundo" dominaria o poder mundial, pois como resultado da expansão do Estado pivô pelas terras marginais eurasiáticas, isto permitiria a utilização de amplos recursos continentais como minérios estratégicos, que possibilitariam a construção de uma enorme frota associando o poder militar ao marítimo, e com isto, constituindo um verdadeiro Império Mundo.

Ao analisar o mundo desta forma, o geógrafo inglês, chamava atenção da Inglaterra que uma aliança entre Prússia e Rússia colocaria a paxbritânica em xeque, colocando a França, a Itália, o Egito, a Índia e a Coréia como cabeças de ponte de onde o poder terrestre se lançaria ao mar influenciando o poder mundial, até então sobre o domínio das potências marítimas. A premissa de Mackinder era a seguinte: "Quem dominar a Europa Oriental controlará o coração continental. Quem dominar o coração continental dominará a ilha mundial. Quem dominar a ilha mundial controlará o mundo" (apud MARTIN, 2004, p24)

Este pensamento ideológico e geopolítico de Mackinder permite pensar que temos aí uma ideologia que é à base de uma estratégia no mínimo interessante, muito longe de termos uma realidade em si mesma, pois isto acabou por não se concretizar. Na verdade a Rússia, ou ex-U.R.S.S - para ser mais preciso com as terminologias - não conseguiu fazer valer sua posição estratégica no continente asiático durante a Guerra Fria. Não houve aí uma tática adequada para dar aos russos a cabeça de ponte que possibilitasse a saída ao mar. Faltou aos russos uma sistemática pautada na grande diversidade dos aspectos da sua geografia que atendesse as estratégias pensadas por Mackinder, e, muito provavelmente faltou habilidade em relações internacionais diante das inúmeras fronteiras, inúmeros interesses, aliados ao isolamento político-econômico. Por isso, o Heartland é ainda muito mais uma 
ideologia do que uma realidade em si. Ora o poder terrestre não conseguiu, pelo menos desde as grandes navegações até os dias de hoje, fazer valer a sua estratégia, por não estabelecer uma análise de como colocar em prática a sua estratégia.

Atualmente, o Heartland já não representa uma posição tão isolada do poder marítimo com os avanços na aviação, balísticas e diante das questões atuais como o aquecimento Global, que torna, cada vez mais, o mar Ártico navegável. Observam-se novas saídas para o Heartland, mas ao mesmo tempo ele se torna mais vulnerável. Mas o que temos é que o Heartland de Mackinder não foi, pelo menos no mundo contemporâneo, o pivot geográfico da história. Depois os desenvolvimentos das forças aéreas, aviões bombardeios e foguetes intercontinentais que poderiam cruzar os céus do Circulo Polar Ártico com muita facilidade, tudo isto, poderia colocar em cheque as teorias do pivot Geográfico da História. Hoje o Ártico é o centro da disputa das potências do norte e por essa razão o extenso litoral da Sibéria pode trazer vantagens aos russos no campo da diplomacia internacional, além do extenso território que disponibiliza todos os minérios importantes para base de seu desenvolvimento.

“O Mundo Segundo Mackinder" (1904-1919)

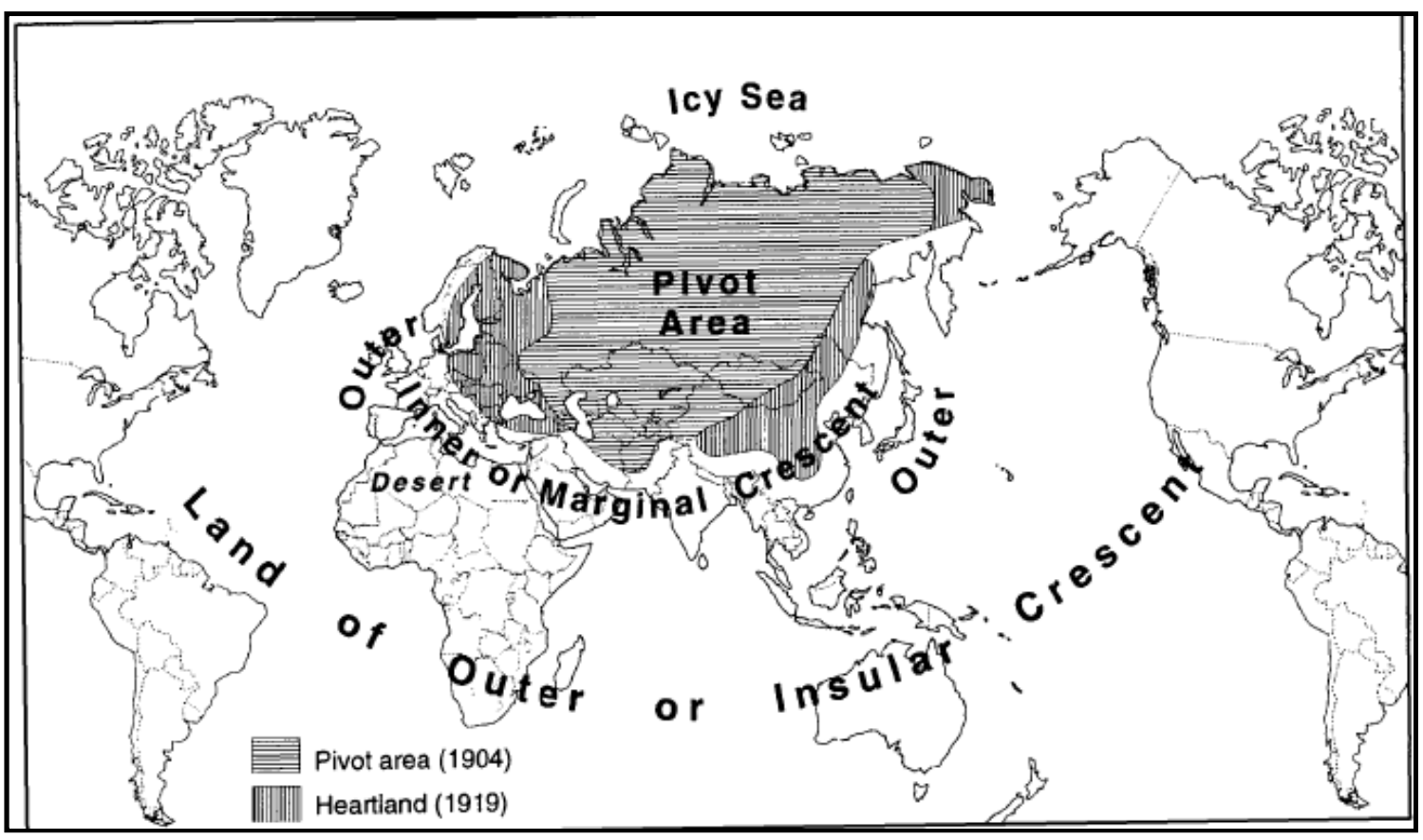

Figura 3- Heartland (COLLINS, 1998: 279) 
Diametralmente oposto as teorias do geógrafo inglês temos a geografia estadunidense e a teoria do Rimland de Nicholas Spkyman - O grande teórico da "escola norte-americana de geopolítica" nasceu na Holanda e viveu apenas 49 anos, mas seu pensamento alimenta até hoje a estratégia de poder global dos Estados Unidos - em seu livro, The Geography of Peace, New York, Harcourt Brace and Company, 1944, definiu uma política de contenção para se desfazer do cerco mundial ao novo mundo que poderia ter ocorrido na II Grande Guerra Mundial se a Alemanha e o Japão tivessem vencido a guerra. Este cerco ocorreria pelo pacífico, liderado pelo Japão e, pelo Atlântico, liderado pela Alemanha. Isto obrigou os Estados Unidos a se desfazer da política do isolacionismo e adotar o globalismo ou 0 intervencionismo como postura político ideológica "a primeira linha de defesa deveria situar-se não no continente americano, mas do outro lado do Atlântico e do Pacífico. Isso significava avançar as forças americanas e posicioná-las nas duas pontos do continente euroasiático" (MELLO,1999:97).

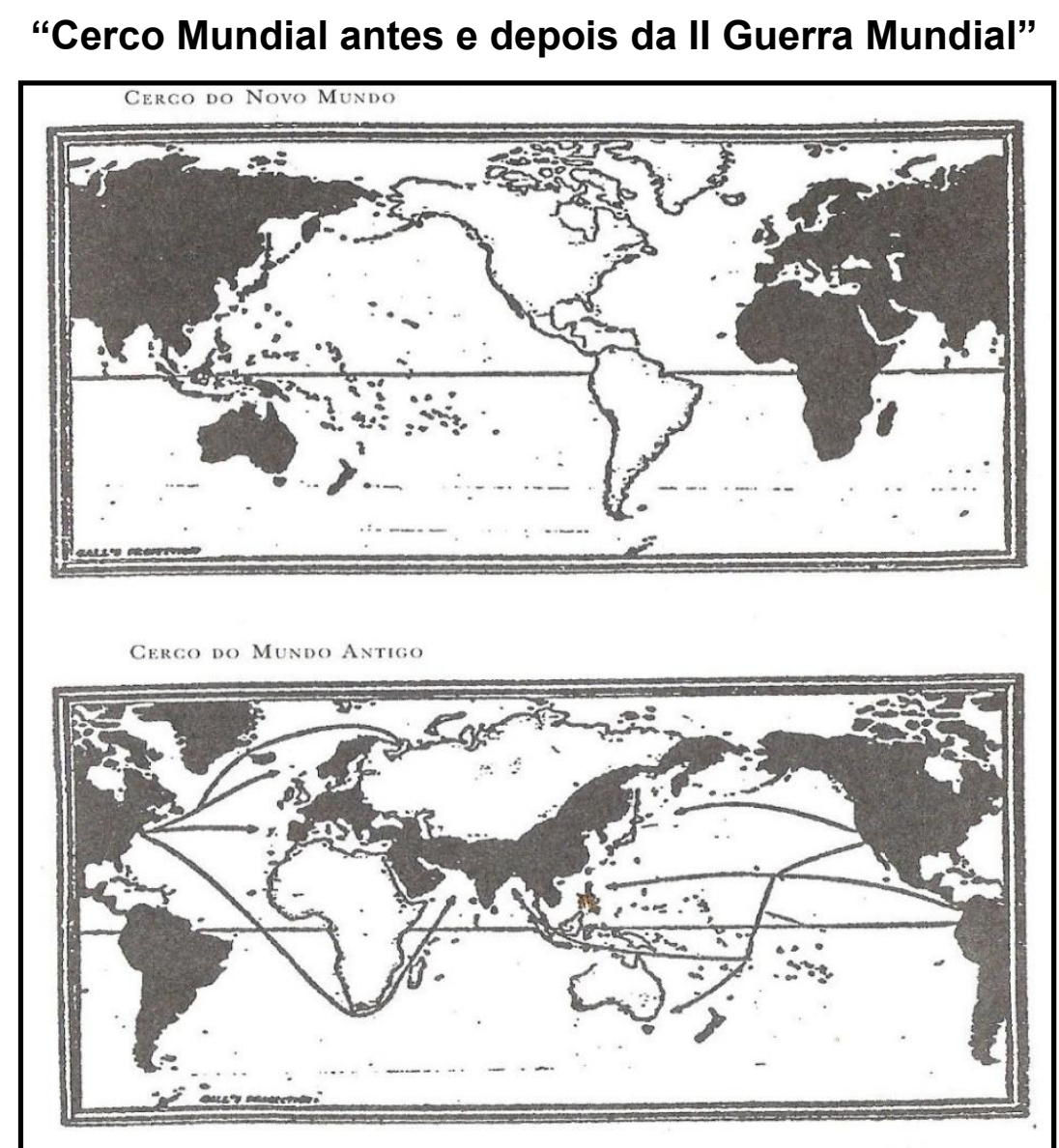

Figura 4 - Fonte: Quem tem medo de geopolítica? (MELLO, 1997:109) 
Ora, os anéis de contenção eram uma política de defesa global por parte dos americanos onde eles definiam grandes áreas de contenção: um anel oceânico no Atlântico - nas ilhas do caribe; no Pacífico - na península do Havaí; as ilhas satélites do continente Eurasiático, Japão e Inglaterra; e um anel na franja do continente asiático, denominado de Rimland, que vai da Coréia até a saída do mar Báltico, passando pelo sudeste asiático, Índia, Oriente Médio, Turquia e Balcãs.

O mais interessante é que diante deste desafio global os americanos construíram uma tática para fazer valer a sua estratégia de contenção, e através do desenvolvimento de uma geografia aplicada, deixando claro que a geografia militar na ciência militar ficou numa certa obscuridade - é certo que os estudos das forças norte-americanas fizeram o caminho da teoria à práxis, caminho este que faltou a política soviética que diante das inúmeras fronteiras se intimidou ao se lançar sobre o Rimland e fazer valer a sua vantagem geoestratégica.

Portanto era importante no pensamento de Spykman que os Estados Unidos associados a uma constelação de poderes do Rimland dividissem o continente Eurasiático para que nenhuma força, ali instaladas, tentasse atrair para si o poder mundial, ou seja, a base da teoria geopolítica do Rimland é o equilíbrio de poder que sempre fora a política inglesa no século XIX que foi capaz de manter a pax britânica com balance of Power, o uso do termo em inglês exprime uma maior exatidão o significado teórico-conceitual.

Para entender melhor o conceito do balance of Power, a análise da "Era dos Impérios", ou o longo século XIX, que foi marcada por certo equilíbrio de poder ${ }^{11}$ europeu, ou balance of Power, é muito valiosa para esta discussão. O processo de equilíbrio de poder - balança de poder - pode ser levado a efeito mediante a redução do peso do prato mais pesado, ou pelo aumento do peso do prato mais leve de uma balança.

Segundo Morgenthau (1948), o equilíbrio pode ser conseguido a partir de diferentes posturas políticas: em primeiro lugar, com a divisão política

\footnotetext{
${ }^{11}$ MORGENTHAU, H. J.- Política entre as nações. "A aspiração de poder por parte de várias nações, em que cada uma tenta manter ou alterar o status quo, leva necessariamente a uma configuração que é chamada de equilíbrio de poder, bem como as políticas que se destinam a preservar esse equilíbrio". (p.321)
} 
interna do rival, o clássico conceito "dividir para dominar"; em segundo lugar, com compensações de ordem territorial; em terceiro lugar, com 0 armamentismo, que de maneira exacerbada pode levar as potências para um conflito total como foi o caso da Primeira Grande Guerra; em quarto lugar, com alianças estratégicas, por exemplo, a França em conflito com a Prússia (Alemanha) e a Rússia em conflito com a Áustria, esta última por sua vez, era aliada da Prússia (Alemanha) contra Rússia e França, a expressão "o inimigo de meu inimigo é meu amigo", famosa máxima da diplomacia inglesa; e por fim, por meio de um "mantenedor" do poder, que irá favorecer ao mais fraco para impedir a ascensão de um Estado que pretende atrair pra si o "poder mundial", ao longo deste século, a Inglaterra desenvolveu este papel, sempre que pode, apoiou o prato mais leve da balança buscando equilíbrio do jogo do poder.

Neste "longo" século XIX, o Império Britânico dominava hegemonicamente as relações ultramarinas e o continente europeu encontrava-se numa situação delicada. A França, exausta pelas "aventuras napoleônicas" e trazida para participar do Diretório da Santa Aliança pela influência inglesa, a Rússia isolada no interior da eurásia e mais seu atraso estrutural, o Império Austro-Húngaro encurralado em sua posição central "estratégica", o recém nascido Império Germânico formado em torno da Prússia, o decadente Império Turco-Otomano que por influencia da Rússia ficou de fora da Santa Aliança por não ser um reino cristão, todos estes estados, com exceção do Império Turco-Otomano, constituíam o diretório da Santa Aliança e formavam uma "pentarquia" de poder, que no continente europeu não havia um poder que se destacasse em relação ao outro, ao mesmo tempo em que uma força anulava a outra.

As melhores palavras para entendermos a postura da política externa inglesa frente aos conflitos no interior do continente europeu e, com isso, entender o balance of power são de Winston S. Churchill em um discurso ao Comitê dos Membros Conservadores sobre assuntos Estrangeiros em 1936:

Durante quatrocentos anos, a política externa da Inglaterra consistiu em opor-se à potência do Continente mais forte, mais agressiva e mais dominadora e, particularmente, em evitar que os Países Baixos caíssem nas mãos de tal potência (...) Observemos que, para política da Inglaterra, não é relevante distinguir qual a 
nação que, em um dado momento, esteja cobiçando o comando da Europa. Não se trata de saber se é a Espanha, ou a monarquia francesa, o império francês, o império germânico ou regime de Hitler. Por isso não deveríamos recear que nos acusem de pró-franceses ou antigermânicos. Se as circunstâncias estiverem invertidas, poderíamos igualmente ser pró-alemães e anti-franceses. Estamos seguindo uma lei pública, e não um mero expediente ditado por circunstâncias acidentais, preferências ou antipatias, ou qualquer outro sentimento similiar (apud MORGENTHAU, 1948, p.372)

Esta lógica explicitada por Churchill, que viria a ser mais tarde 0 primeiro-ministro, é o cerne da diplomacia inglesa e foi o que fez com que Lord Castlereagh, mais de um século antes, trouxesse a França para o Diretório da Santa Aliança para fim de manter o equilíbrio no continente europeu. Enquanto as potências continentais resolviam questões fronteiriças a Inglaterra comercializava e se industrializava, em um momento em que tínhamos um processo de desarmamento da Europa que estava horrorizada com os resultados catastróficos das guerras napoleônica, chamada, na época, de a Grande Guerra.

$\mathrm{Na}$ primeira metade do século XIX se estabeleceu a "paxbritânica". O Império Britânico, então, expressava o poder marítimo que funcionava como fiel da balança para manter o equilíbrio entre as potências continentais. Atuando de acordo com seus interesses geopolíticos ora apoiando a França contra a Rússia, ora incentivando o Império Turco-Otomano para bloquear o estreito de Dardanelos, a saída do Mar Negro para o Mediterrâneo, sempre que possível buscavam que as potências continentais anulassem o poder uma das outras mantendo a balança do poder bem equilibrada.

Portanto, o isolacionismo era uma estratégia que confiava excessivamente no fato que os oceanos funcionavam como uma verdadeira fortaleza para os americanos e os acontecimentos da Segunda Guerra Mundial com a aliança nipo-germânica poderiam neutralizar o poder da ex-U.R.S.S. e a China. "Se a constelação nipo-germânica de poder conseguisse conquistar a Rússia e a China, unificando as duas extremidades da Eurásia, poderia desenvolver um poder anfíbio" (MELLO, 1999:108). 
Essa confiança da política isolacionista na geografia, talvez a mesma confiança que Mackinder tinha que o Heartland, um pedaço de terra na Sibéria, fosse por si só suficiente para vencer a guerra seria um erro estratégico basilar segundo a visão de Spykman, pois se no caso de vitória da associação Japonesa e Alemã no continente euroasiático, estes poderiam "neutralizar os Estados Unidos mediante um envolvimento estratégico e suplantar a influência norte-americana no hemisfério ocidental" (Ibdem, 1999:108). Então os Estados Unidos cometeriam um erro gigantesco ao considerar a posição geográfica privilegiada para a defesa, com dois oceanos servindo como barreiras intransponíveis, este erro pode ser identificado como um erro de geografia militar ao confiar demais nos fatores geográficos e menos nas novas possibilidades tecnológica e nos novos arranjos geopolíticos.

Os preceitos de Spykman - o globalismo ou intervencionismo estavam mais ajustados a realidade dos Estados Unidos, influenciar mais o poder mundial do que o isolacionismo que funcionou como uma boa estratégia de defesa no século XIX. O poderio estadunidense depois da Segunda Grande Guerra Mundial não permitiria mais uma tímida política de defesa. A partir de então, a melhor estratégia para defesa seria o ataque, poderíamos dizer que a Doutrina Monroe (1823) seria expandida de uma política regional (bairrista) para uma política intervencionista global, onde os planos de defesa dos Estados Unidos estão além de suas fronteiras - diante das novas tecnologias e dos novos arranjos da geopolítica da Guerra Fria. E a tônica da teoria e da prática da política internacional estadunidense se resume nas palavras do próprio Nicholas Spykman em The Geography of Peace, 1944:

Em outras palavras, nunca houve na realidade esquemática oposição terrestre versus o poder marítimo. O alinhamento histórico sempre foi de alguns membros do rimland com a Grã-Bretanha e Rússia, ou então Grã-Bretanha e Rússia juntas contra um poder dominante no rimland. O ditado de Mackinder é falso. Se é pra ter algum slogan para política de poder no Velho Mundo, este deve ser: "Quem controla o Rimland domina a Eurásia; quem dominar a Eurásia controla os destinos do Mundo". (apud MELLO, 1999:125) 
Concluindo este raciocínio, para manter o equilíbrio do poder os Estados Unidos deveriam impedir de todas as formas, uma união, ou aliança de interesses predominantes no continente eurasiático, mantendo-o fragmentado e dominando suas cabeças de ponte mantendo um certo equilíbrio de forças no continente euroasiático.

Para concluir, estudos práticos sobre guerras em florestas tropicais, desertos, montanhas foram realizados ou reunidos e usados em diversas guerras como: a guerra do Vietnã, a Intervenção em Kosovo, a Guerra do Golfo, a Guerra do Afeganistão e a Guerra do Iraque. São estudos que serão contemplados e pormenorizados na segunda parte deste estudo. 


\section{CAPÍTULO 3}

\section{DA ARTE DA GUERRA À CIÊNCIA DA GUERRA: AS TEORIAS DA GUERRA E SUAS CONCEPÇÕES GEOGRÁFICAS.}

\section{Introdução}

O pensamento filosófico das teorias da guerra evolui da arte à ciência, lembrando que no Oriente a filosofia da guerra é parte das artes marciais que são demasiadamente complexas, com técnicas que vão da criação dos artefatos bélicos, passando a técnicas do manuseio, até a filosofia e religião. Os samurais japoneses tinham um ensinamento de regra e conduta para os guerreiros santos, este, era o Bushido, os indianos têm um dos quatro vedas, livros sagrados - Arthashastra - dedicado a política, diplomacia e guerra. No século XIX, a ciência começa a ocupar o espaço das artes e começam a se dissociar, portanto não existe mais uma grande arte que envolva técnicas, filosofias, religiões e sim manuais de como vencer as guerras em determinadas situações, ou quais erros que não poderiam ser cometidos pelos generais em condições específicas, levando em conta experiências anteriores. É verdade, também, que nem sempre as situações anteriores podem servir como lição em momentos posteriores, por que cada caso é um caso e tem suas próprias especificidades, mas toda experiência é válida e cabe ao líder do Estado Maior saber interpretá-las para melhor conduta de seus exércitos.

Não cabe nesta discussão realizar o levantamento histórico pormenorizado das teorias da guerra, pois o trabalho ficaria muito extenso, mas realizar um breve levantamento de como as concepções geográficas evoluíram do pensamento antigo aos padrões atuais de apropriação do espaço por meios bélicos e quais proposições que são válidas ainda hoje, ou mais, quais relações que se estabelecem diante da teoria e de uma experiência experimentada. As escolhas de alguns teóricos específicos estão relacionados à sua importância e relevância para o debate em questão.

Antes da análise destas teorias cabe ressaltar que esta construção teórico-metodológica já foi bastante explorada. Heinrich Zimmer, autor de Filosofias da Índia, demonstra muito bem como uma teoria mesmo 
antiga e ligada a preceitos da religião como Arthashastra Veda, pode nos ajudar a entender a postura de algumas potências, através de uma leitura comparada.

$\mathrm{Na}$ parte II de seu trabalho, o primeiro capítulo nos fala da filosofia hindu de como obter êxito na administração pública e nas relações de poder que se estabelecem a partir da existência de um poder identificado como o Estado. Este compêndio de versos se encontra no Arthashastra Veda, e em outros compêndios como: Mahabharata, Ramayana, e outras fábulas indianas que nos falam, não só da espiritualidade, mas também, de estratagemas político-estratégicos.

Zimmer nos descreve a mandala ou círculo político de estados vizinhos que esta descrita no Arthashastra: "esta fórmula para dispor alianças e coligações estrangeiras é fundamentada num diagrama de anéis concêntricos que representam os inimigos e aliados naturais" (ZIMMER, 1986:89). O líder deve considerar seus domínios como o círculo central, seus inimigos naturais os que o cercam, e os seus aliados naturais os que cercam seus inimigos (ver a figura 5), e no último círculo uma ameaça remota. A mandala "delineia e torna manifesto certo equilíbrio e tensão entre forças naturais (...) Como princípio social válido universalmente, supõe-se que os vizinhos são propensos à inimizades, à inveja e agressão" (ibidem, 1986:89). Esta teoria pode ser vista como exemplo em vários episódios de conflitos durante a pax-Britânica no longo século XIX, onde se prevaleceu o balance of Power e no caso mais evidente as posturas políticas da França no século XVI, XVII e XVIII, como bem descreve o autor:

\section{"Mandala da política de estados vizinhos"}

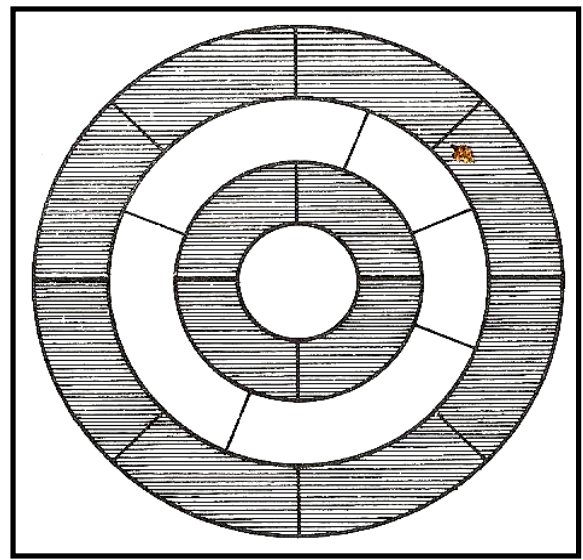

Figura 5 - Fonte: Filosofias da Índia. (ZIMMER, 1986:89) 
Quando aplicamos o antigo mandala da Índia ao mapa da Europa, obtemos um diagrama perfeito dos problemas e vicissitudes, dos acertos e dos aparentes enganos, que provocam nossas quase ininterruptas guerras. No começo da época moderna, no século XVI, a França encontrava-se ameaçada pelo cerco resultante da união entre a Espanha e o Império Germânico sob a dinastia dos Habsburgos. A subseqüente luta pela hegemonia entre os reis franceses e os imperadores de Viena- desde os reinados de Francisco I (1515-1547) e Carlos V (1519-1556) - estendeu-se até 0 desmembramento do Império Austro-Húngaro quando do Tratado de Versalhes em 1919. Luis XIV (1643-1715) "o mais cristão dos reis", que perseguiu os calvinistas huguenotes e os expulsou de seu reino - conseguiu 0 apoio dos turcos otomanos que estavam às costas dos domínios dos Habsburgos na Europa oriental. Então os turcos invadiram os territórios do inimigo desde que hoje é a (ex-) lugoslávia passando pela Hungria, enquanto os exércitos franceses lutavam contra as forças imperiais alemãs nos Flandres e ao longo do Reno. (ZIMMER, 1986:90)

Uma análise como esta, do texto antigo sem a roupagem do cientificismo que fora germinado no século XIX e que acompanhou todo século XX. Onde a ciência se pretendeu a substituir a religião como conhecimento e muitas vezes subestimaram esses pensamentos milenares classificando-os por "proto-filisofia" segundo a definição de Hegel que distinguiu o pensamento dos gregos como a verdadeira filosofia e os pensamentos orientais como uma espécie de pensamento primitivo.

Atualmente, este é o paradoxo vivido nas sociedades orientais diante dos novos valores que são impostos pela globalização. Jogar fora todo o conhecimento transcendental das filosofias orientais e ficar com o pragmatismo científico? Zimmer mostra como pode ser feita a ponte entre tais filosofias e a ciência moderna.

O pensamento científico não deve ficar longe da origem da sistematização do pensamento da humanidade que foram as religiões e filosofias, pois nestas estão o motivo primeiro da curiosidade humana e que fez dos seres humanos muito diferentes dos outros seres vivos. Esta experiência deve sempre pautar todas as futuras indagações, para que não caiamos mais uma vez no erro de usar os conhecimentos desenvolvidos com interesses individuais, que não o interesse da humanidade, como foi feito com o 
desenvolvimento das bombas atômicas e é feito ainda hoje, para gerar lucros para poucos e explorar a crescente miséria humana. A nossa atual ciência esta comprometida, não com a melhoria da qualidade de vida, mas com um pequeno grupo de grandes corporações, enquanto o pensamento das filosofias e religiões orientais estava mais relacionado ao desenvolvimento interior dos indivíduos, com o aperfeiçoamento do próprio indivíduo, assim a mudança do particular aconteceria e como conseqüência à melhoria do convívio entre as diferentes sociedades.

Isto, também, não quer dizer que estas filosofias e religiões não consideravam o temperamento ávido dos diferentes indivíduos de diferentes sociedades, por isso, alguns destes tratados religiosos, principalmente dos hindus, refletem situações políticas, onde o poder é alvo de disputa e usado com fins pessoais, por isso a importância de se falar de política e de como usar melhor o poder, conseguindo a paz, prosperidade e tranqüilidade para a população e para evolução espiritual.

Analisando a filosofia hindu, Zimmer, comparou certas situações experimentadas no berço da civilização ocidental e que repercutiram, segundo o autor, até o Tratado de Versalhes em 1919, mas que podem ser reconhecidas na II Grande Guerra Mundial, como a oposição entre França e Alemanha e a posterior aliança da França com a Inglaterra - esta sempre com a intenção de estabelecer o equilíbrio do poder no continente, como já foi comentado anteriormente - muito próximo do esquema proposto pela mandala do poder no Arthashastra Veda.

\section{A arte da guerra de Sun Tzu e sua geografia marcial}

Numa recente publicação de A Arte da Guerra de Sun Tzu e de Métodos Militares de Sun Pin (provável descendente de SUN TZU) - obra que ficou perdida durante séculos - Raphael Sawyer organizou e comentou numa mesma edição estas duas obras basilares do pensamento estratégico chinês antigo, publicado na edição brasileira da Martins Fontes em 2002, primeira edição. A visão estratégica de Sun Tzu, atualmente, é aplicada em treinamento de executivos que lêem os preceitos de a Arte da Guerra e o aplicam no mundo do negócio, o que pode ser catastrófico sendo que o próprio pensador 
recomenda que o ápice da excelência não é vencer mais de cem batalhas e sim "subjugar o exército inimigo sem lutar" (SUN TZU apud SAWYER,2006:62). Portanto, é incoerente em meio ao um ambiente de extrema concorrência aplicar de maneira vã os ensinamentos de Tzu, que segundo as suas próprias palavras diz que "a guerra é o Tao do ardil" (ibidem, 2006:51). É por isso que observamos no mundo coorporativo, jovens executivos com suas saúdes tão comprometidas, principalmente com problemas do coração e estômago.

Segundo SAWYER (2006), Sun Tzu viveu na China Antiga num período denominado de "O período de Primavera e Outono" (722-481 a.C) onde emergiram estados ligados a importantes famílias feudais - Chou (a mais antiga), Wu (lar de Sun Tzu), Yueh (inimigo de Wu e que incorpora mais tarde o estado de $\mathrm{Wu}$ ), Chin (que no final do período havia formado uma força capaz de usurpar o poder de Chou, e podia facilmente mobilizar 75.000 homens sempre que necessário), Ch'i (na costa leste junto ao mar Amarelo), Chao (ao norte) e Chu (que estimulou o pensamento de Sun Tzu pelo fato de possuir uma geografia peculiar na região) - entre as bacias dos rios Huang Ho e o Yangtse Kiang. Então na disputa pelo poder observa-se uma divisão bem clara os Estados mais tradicionais ao norte do Estado de Chou e os novos estados que se encontravam ao sul, ao longo do Rio Yangtse Kiang que eram menosprezados pelas famílias do norte, mas cresciam rápido desenvolvendo áreas inóspitas. Sun Tzu previu muitas coisas ao fazer uma prospecção geográfica dos territórios do sul, Chin (principalmente), Chu e Ch'i, como foi analisado:

O sul gozava de entre as quais um clima mais quente e produtivo, recursos aquáticos (hídricos) abundantes e extensos rios, lagos, montanhas e florestas densas. Um bastião natural que freqüentemente tornava inúteis as guerras que se utilizavam carros, o território desencoraja invasões pelo norte, ao mesmo tempo em que compelia o desenvolvimento das forças navais. Essas forças navais do interior aproveitam-se das habilidades que os nativos haviam desenvolvido para explorar os rios Yangtse, Han e Huai, os numerosos lagos e os extensos charcos. (SAWYER, 2006:2) 
Sun Pin, o provavelmente descendente de Sun Tzu, viveu no Período dos Reinos Combatentes (403-221 a.C), onde a guerra entre os estados feudais passou a ditar impreterivelmente a política e as relações entre os Estados. Neste período observa-se a predominância de quatro estados Chin, Ch'u, Ch'i e Yueh. Chin, o estado mais a oeste se fragmentou em três estado Han, Wei e Chau, conhecidos como os "Três Chin" (ver figura 6). Chin por sua posição estratégica se beneficiou da luta nos estados centrais "que ao final derrotou todos os poderes menores restantes, proclamando formalmente a dinastia Chin em 221 a.C., desenvolveu agressivamente sua base de poder no terrirório original de Chou" (SAWYER, 2006:11). Neste período a infantaria se transformou na principal força de combate substituindo de maneira importante os carros e a cavalaria. O general Sun Pin utilizava os carros não como força de combate e sim como força móvel utilizando os carros e as cavalarias como carretas de guerra.

\section{“Os Reinos Combatentes"}

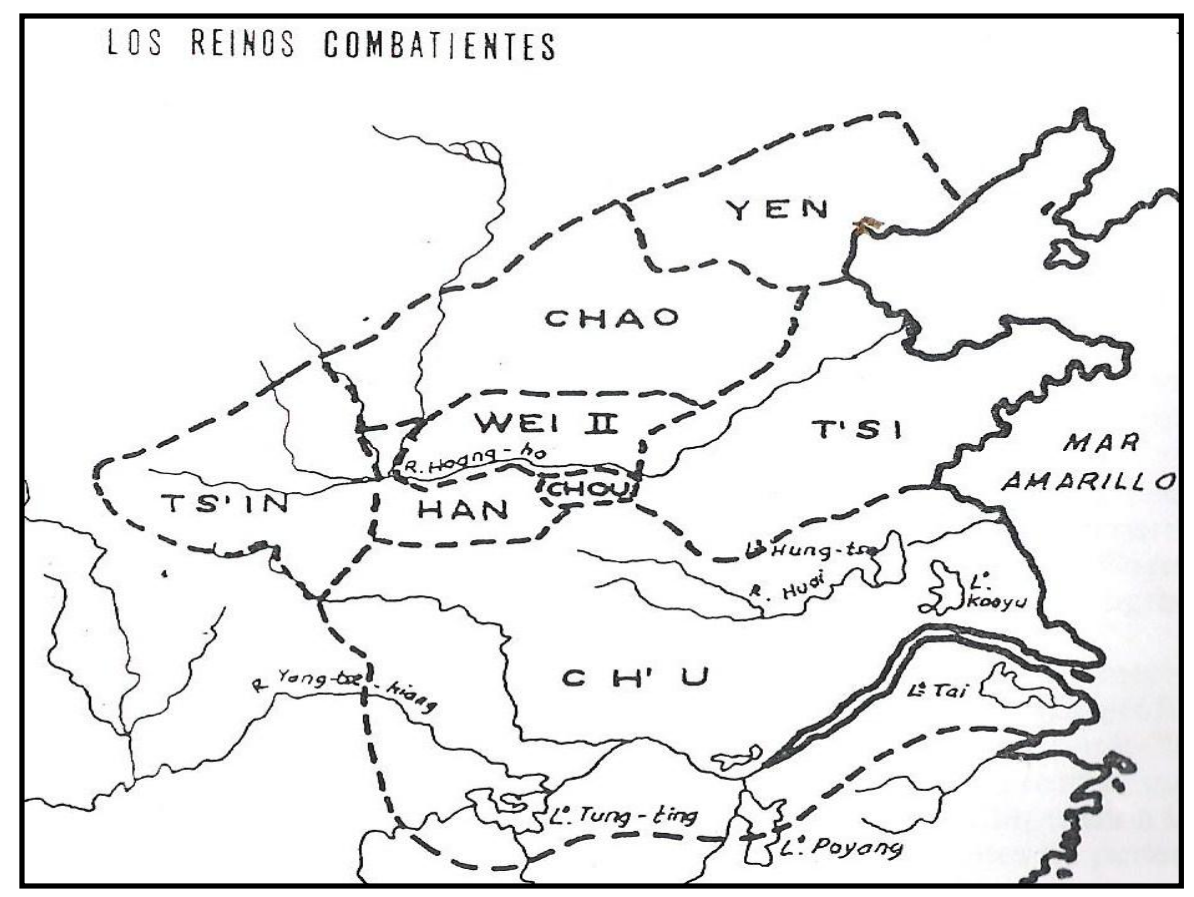

Figura 6- Fonte: La Geografia y la guerra: un analisis de sus relaciones (CEBRIAN, 1986:37)

Nos fundamentos de a Arte da Guerra, a primeira lição no primeiro capítulo Sun Tzu alerta que a guerra deve ser domínio do Estado e pode ter efeitos desastrosos como a extinção do Estado ou em certos casos 
como a única saída de sobrevivência dele. Sun Tzu divide o estudo em cinco partes: "O primeiro é denominado do Tao, o segundo Céu, o terceiro Terra, o quarto generais e o quinto leis da organização e da disciplina militar". (op. cit. 2006:51). Pelo menos uma parte é dedicada exclusivamente à geografia da guerra, e esta será alvo de debate e analises neste campo de discussão.

Em todos os capítulos Sun Tzu ressalta os fatores relacionados com a geografia da guerra como algo importante, pois ele esta estudando a arte de mobilizar exércitos, no capítulo 2 - Realizando a Guerra - ressalta o planejamento e a organização militar para realizar a mobilização das tropas e mostra o quanto isto custa para o Estado. O grande conselho é que a empresa da guerra não seja prolongada, pois isto pode atolar o Estado em dívida e infelicidade geral da sociedade. Portanto a guerra só é aconselhada se a empresa for rápida e trazer grandes vantagens para o Estado em questão.

País algum jamais se beneficiou de guerras prolongadas. Aqueles que não compreendem profundamente os perigos inerentes ao emprego do exército são incapazes de conhecer verdadeiramente as vantagens potenciais das ações militares. (op. cit. 2006:56)

Esta filosofia inicial pode muito bem ser pensada diante da política de guerra alemã no início da II Grande Guerra Mundial, a Blitzkrieg, ou guerra relâmpago, que previa ataques rápidos em lugares onde o inimigo não teria força alguma para resistir, foi assim com a Polônia, Áustria, Países Baixos, Bélgica e França. Entretanto, a Alemanha errou ao expandir a guerra para leste europeu com a União Soviética, então a guerra se prolongou e os extensos gastos militares alemães implodiram o Estado, e quase pôs fim ao Estado alemão, este mesmo, que foi fragmentado entre as potências vitoriosas, mas que hoje se encontra reunificado.

No capítulo 3 - Planejando a ofensiva - Sun Tzu desenvolve o seu postulado central, bastante relacionado com o estudo da geografia militar: "Aquele que conhece o inimigo e a si mesmo não correrá perigo algum em cem confrontos" (SUN TZU apud SAWYER, 2006:64). Para isso se faz necessário conhecer sobre as potencialidades do Estado, da organização de seus exércitos, o ímpeto de seus generais e principalmente o seu território. 
No capítulo 4- A disposição militar - Sun Tzu afirma que é a partir do território que deve ser feita as mediações necessárias para se obter uma melhor disposição de suas forças:

O terreno dá a luz à mediação; a mediação produz a avaliação dos exércitos. A Avaliação do exércitos dá origem ao cálculo do número de homens. O cálculo do número de homens da origem a ponderação da força. A ponderação da força da luz a vitória. (op. cit. 2006:71)

Entretanto, os capítulos que Sun Tzu mais se dedica a arte do conhecimento do terreno são os capítulos: 9 - Manobrando o exército; 10 - A configuração do terreno; e por fim, 11 - Nove terrenos. É sobre estes capítulos que o debate sobre a geografia militar é melhor desenvolvido no pensamento de Sun Tzu, embora todos os capítulos façam referências diretas e retas sobre as vantagens de se conhecer o terreno do combate.

Essa discussão por questões didáticas é melhor que se comece pela definição dos Nove terrenos e pela configuração do terreno. No capítulo 10, Sun Tzu define cinco configurações de terreno que podem variar em nove tipos de terreno: "As principais configurações de terreno são cinco: acessível, suspenso, paralisado, restrito, íngreme e extenso" (SUN TZU apud SAWYER, 2006:110).

Segundo Sun Tzu, acessível é aquele que se pode prosseguir com facilidade, e o inimigo também; suspenso é aquele que prosseguir é fácil, mas o retorno não; paralisado é aquele que não é vantajoso para prosseguir e nem para o inimigo; restrito é aquele terreno que dá grandes vantagens se ocupado primeiro que o inimigo se for ao contrário não é bom que se siga adiante; íngreme é aquele em que deve ocupar as áreas mais altas; extenso é aquele que não é vantajoso travar o combate. Sobre a configuração do terreno Sun Tzu afirma:

A configuração de terreno é um auxílio para o exército. Analisar o inimigo, deter o controle da vitória, avaliar ravinas e desfiladeiros, o distante e o próximo, são o Tao do general superior. Quem os conhecer e os empregar no combate será vitorioso. Quem não os conhecer ou não os empregar no combate será certamente derrotado. (op. cit. 2006: 111) 
No capítulo 11- Nove terrenos - Sun Tzu define os nove tipos de terreno no qual serão feitas algumas análises: terrenos dispersivos (quando os senhores lutam em seu próprio terreno); terrenos leves (quando a ocupação invasora não é profunda); terreno contencioso(quando vantajoso para quem ocupa); terrenos atravessáveis (de fácil travessia tanto para os aliados como para o inimigo); terrenos delimitados (A terra dos senhores feudais cercada de três lados de modo que quem chegue primeiro ganhará as massas de Tudo que há sob o Céu); terrenos pesados (quando se penetra profundamente em território inimigo); terreno capcioso (onde existem florestas, ravinas e desfiladeiros, pantanais e charcos, onde quer que a estrada seja difícil travessia); terreno cercado (onde a entrada é restrita, a volta é tortuosa, e com um pequeno número o inimigo pode atacar as nossas massas); terreno fatal (não trás vantagens e que lutar com mais intensidade sobreviverá e quem não lutar com intensidade perecerá).

A Guerra do Vietnã é um bom exemplo de que os conselhos do antiqüíssimo Sun Tzu devem ser considerados em sua relevância. Primeiro os Estados Unidos não fizeram um plano de guerra rápido, o que elevou muito os gastos e desgastou suas forças na região. O segundo preceito que é conhecer o seu inimigo e a si mesmo não fora levado em consideração, pois o poderio militar estadunidense era tão mais forte que acharam que a guerra não demoraria tanto. As forças norte-americanas estavam entrando em terreno capcioso e em terreno pesado. Ora, segundo os conselhos de Sun Tzu "em terreno capcioso se atravessa velozmente" e quando se entra profundamente no território as forças devem manter-se unidas.

Os vietcongues, muito pelo contrário, seguiram - mesmo que instintivamente - os postulados de Sun Tzu, e fizeram com que as forças inimigas entrassem profundamente em terreno capcioso e dividiram os exércitos yanques a fim de isolá-los em seu território, para atacar um a um em emboscadas. A prática da guerrilha faz parte dos métodos heterodoxos de Tzu, surpreender o inimigo onde ele não espera; se ele é numeroso e nós pequenos ele é devagar e nós rápidos, isto num terreno lento é uma grande desvantagem para $o$ assaltante, portanto dividir e isolar o inimigo para que possa utilizar 0 território como vantagem em guerra. 
Assim, se eu precisar a disposição do inimigo sem ter eu mesmo uma forma perceptível, posso concentrar minhas forças enquanto o inimigo esta fragmentado. Se estamos concentrados em uma única força enquanto ele está fragmentado em dez, então atacaremos dez vezes a sua força. Assim somos muitos e o inimigo é parco. Se pudermos atacar seus poucos com nosso muito, aqueles com que travarmos batalha ficarão extremamente pressionados. (op. cit. 2006:83)

As guerras do final do século $X X$, quando os mega estados subjugam militarmente os países da periferia, têm o caráter de guerrilha e tem como principal teórico Sun Tzu. Pois não há como enfrentar um inimigo muito superior em armamento, organização, treinamento em confrontos diretos, e para Sun Tzu a ética da guerra é manter o poder, mesmo que seja necessário usar as artimanhas, os métodos heterodoxos, neste caso as guerrilhas. Temos diversos exemplos da luta de guerrilha na América Latina, África, Ásia como focos de resistência a forças maiores, no século XX e o início do século XXI, quando se observa o Oriente Médio, a situação não irá ser diferente.

\section{Flavio Vegécio Renato, Marco Polo e Nicolau Maquiavel: pensadores da guerra além do seu tempo e espaço}

Avançando um pouco o tempo e passando por cima das considerações de alguns dados descritivos apontados por outros autores, e historiadores-cronistas que interessados em incluir dados do ponto de vista estritamente militar estavam mais preocupados com as grandes batalhas e suas táticas, do que com a arte de conduzir campanhas em sua estratégia. Assim, o corte teórico poderia ser feito de maneira a incluir outros pensadores como Platão, Xenofonte, Aristóteles que foram muito influentes no pensamento sobre a arte da guerra e influenciaram Alexandre Magno, Júlio César, os maiores conquistadores e generais da história ocidental, estes por sua vez impactaram de maneira basilar os pensamentos de Flavio Vegécio Renato (século IV d.C) e Nicolau Maquiavel (início do século XVI); a influência oriental é trazida principalmente por Marco Pólo que com Kublaikan, o grande Kan, apreendeu muito sobre a inteligência da guerra e a informação. 
Segundo CEBRIAN (1985), através de sua obra Instituições Militares (De re militari) que não foi uma obra sobre a tática, Vegécio destaca um assuntos, pouco comentados até então na discussão da arte da guerra, que foi o recrutamento relacionado com critérios geográficos. No primeiro livro, capítulo III, Vegécio identifica que os melhores recrutas são os homens do campo "que para a guerra não existe gente melhor que a do campo que é criada nas inclemências do tempo". (VEGÉCIO apud CEBRIAN, 1985:35). No entanto quando for necessário recrutar os cidadãos - homens que vivem na cidade ou citadino - o trabalho para acostumá-los é intenso sendo necessário separá-los dos deleites da cidade.

A maior contribuição de Vegécio a geografia militar se encontra na sua obra Geografia dos Mares, especialmente no mar Mediterrâneo. No livro $\mathrm{V}$ - Da guerra do mar - o pensador discorre de temas sobre climatologia, o que ensinam as tempestades e os ventos, quais meses melhores para se navegar com segurança o mar Mediterrâneo, quais sinais anunciam tempestades, das correntes marinhas, e do conhecimento das costas, portos naturais, e das manobras das embarcações. Vegécio diz que "As boas elucidações da geografia dos mares e terrenos são mais úteis do que a força" (apud CEBRIAN, 1985:36).

Durante a Idade de Média, o avanço do pensamento militar ou da arte marcial, assim como dos conhecimentos da geografia, ocorreu no Oriente Médio. Os mulçumanos foram os que mais desenvolveram os conhecimentos da geografia neste período, enquanto que a Europa mergulhava na obscuridade geral. KIMBLE (2005), em A geografia da Idade Média, destaca o apogeu desta cultura que salvaguardou o conhecimento dos pensadores gregos como Ptolomeu, que foi um dos mais importantes Geógrafos da antiguidade, ao traduzir para o árabe com muito mais fidelidade que os tradutores latinos. Os conhecimentos geográficos foram desenvolvidos em sua expansão a jihad - expansão do islã, traduzido como guerra santa - e a hajj que é a peregrinação religiosa a Meca que todo o mulçumano deve fazer pelo menos uma vez na vida. Portanto, pelo costume de estarem sempre em movimento, os árabes reuniram rapidamente uma vasta sabedoria sobre os conhecimentos geográficos mundiais conhecidos da época. 
Se alguém, no início do século VII, tivesse a audácia de profetizar que, dentro de uma década, um poder desconhecido, o dos povos da Arábia até então bárbaros e pouco conhecidos, pudesse surgir e afirmar-se perante as duas potências da época, tornando-se herdeiro dos persas e roubar dos bizantinos uma de suas mais bonitas províncias, inegavelmente poderia transformar-se em alvos de risos. E foi exatamente isso que aconteceu. Próximo à data da morte do Profeta (632), a Arábia tinha se transformado, como um passe de mágica, num viveiro de heróis difíceis de serem enfrentados. As campanhas militares de AI Walid e Al-Ã, que atravessaram o Iraque, Pérsia, Síria e Egito, estão entre as mais brilhantes na história das batalhas e podem ser comparadas com as de Aníbal, Alexandre e Napoleão. (KIMBLE, 2005:53)

Por estar numa posição central entre o ocidente e o oriente a geografia dos árabes soube reunir dados e informações sobre a Terra, mais do que qualquer outra civilização daquele momento. Segundo KIMBLE (2005), no século $\mathrm{XI}$, os árabes tinham a posse de informações sobre a costa leste da África até $20^{\circ}$ Sul; como por exemplo, até Sofala. No entanto era absolutamente desconhecido o oceano Atlântico, o nordeste da Europa e o leste da Ásia, assim como para eles das quatro partes da Terra só uma delas era habitável; ao sul do equador estavam às áreas acúmenas, para usar o termo grego que bastante influenciou o pensamento da geografia árabe.

No oriente, no século XII, os mongóis foram grandes mestres na geografia militar e Gengis Kan (1155-1227), antes e durante suas operações militares, considerou de grande importância a obtenção de quantos dados fosse possível sobre os países próximos ou distantes de seu império. O seu objetivo era de conhecer as características geográficas, situação política, aspectos militares com a finalidade de proporcionar ao imperador um panorama geográfico e político das regiões descobertas. Mais uma vez, aparecem sistematizações similares aos componentes dos estudos de geografia militar e que foram necessários aos sucessores de Gengis Kan.

Esta sistematização foi bem constatada pelo grande viajante italiano Marco Pólo (1254-1299) que em seus relatos demonstra como o Grande Kan (Kublaikan 1214-1294) usava seus mensageiros como informantes, e quais eram as informações mais importantes que eles deveriam trazer de volta de suas viagens. Os questionamentos de Kublaikan eram 
sempre a respeito dos: aspectos físicos - forma, extensão, relevo, solos, hidrografia, clima, fauna e flora; fatores humanos - tamanho da população, raça, idioma, religião cultura, nível de vida e saneamento; fatores econômicos política econômica, moeda (sistema financeiro), produção, comércio, vias de comunicação; fatores sociopolíticos - fronteiras, organização sociopolítica, política interna e externa; fatores militares - estruturação das forças armadas, exército, marinha, recrutamento e mobilização, armamento e material. Se observarmos o fluxograma Esquema sintético para um estudo de geografia militar proposto por CEBRIAN, 1985, perceberemos que o Grande Kan, mesmo que instintivamente realizava a sua própria geografia militar:

"Fluxograma sintético para um estudo de Geografia militar"

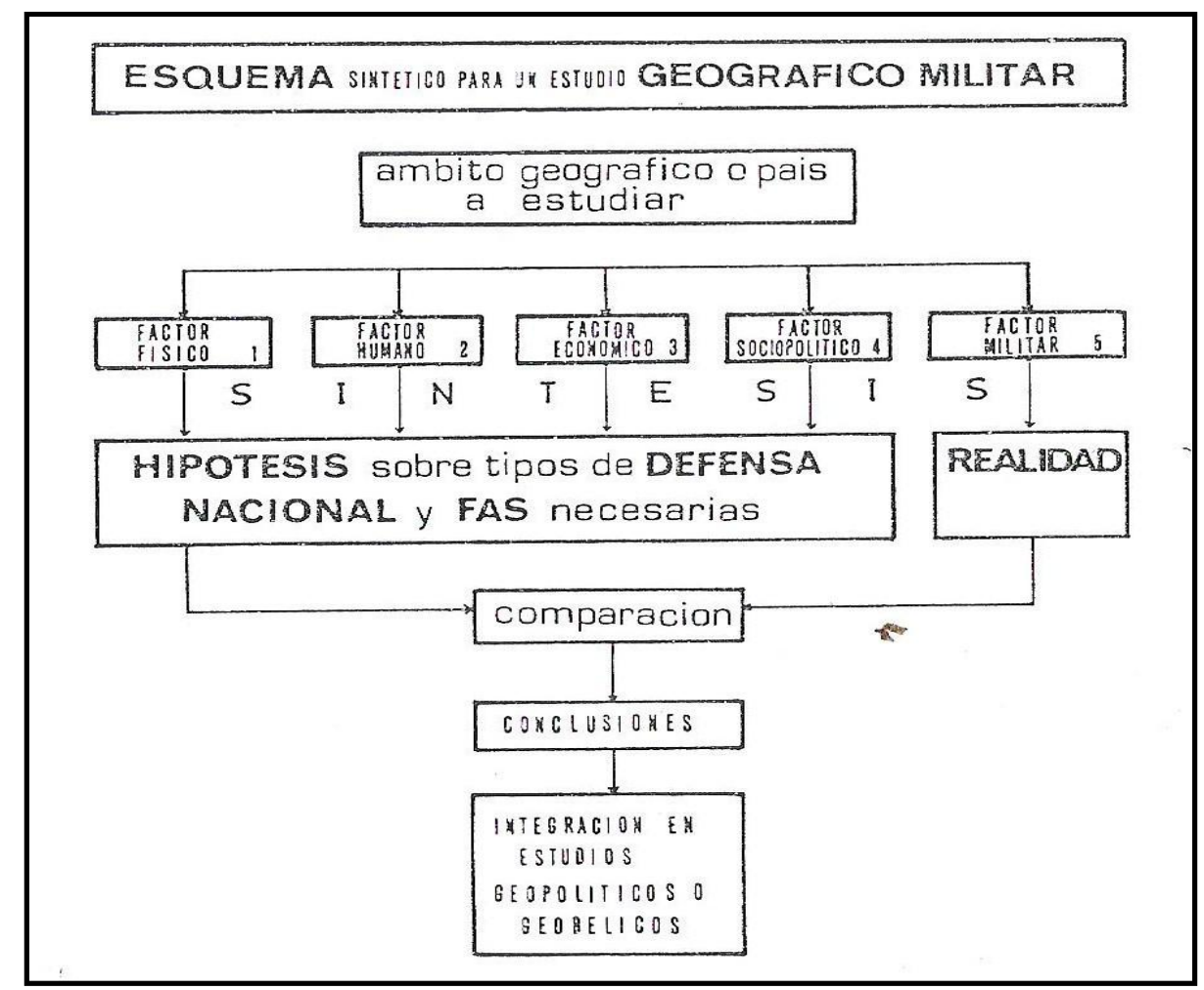

Figura 7- Fonte: La Geografia y la guerra: un analisis de sus relaciones (CEBRIAN, 1986:43)

Avançando para o Renascimento, aparece como o pensador que inaugura o pensamento político moderno, Nicolau Maquiavel. Sua obra mais importante e tida como inauguradora do pensamento político é $O$ príncipe (1513). Neste debate nos interessa analisar o pensador do ponto de vista da geografia militar, para tal, a obra mais importante de Maquiavel é A Arte da 
Guerra (1521), neste verdadeiro tratado militar, escrito em prosa, Maquiavel expõe seu pensamento sobre a estratégia e sobre a arte do comando.

Segundo LYNCH (2006) - na Introdução de $A$ arte da guerra publicada pela Chicago University, que se encontra na edição brasileira Maquiavel é muito influenciado por dois antigos autores romanos, Vegécio e Frontino. Ele se apóia nas grandes façanhas de comandantes antigos como César e Alexandre e outros. "Entre estes estão Pelópidas e Epaminondas, Túlio Hostílio, Filipe da Macedônia, pai de Alexandre, Ciro rei da Pérsia, Tibério Semprônio Graco. Todos estes tiveram antes de criar um bom exército para depois combaterem" (op. cit. 2006:220).

Ao pensamento de Maquiavel, sua compreensão se faz a partir de sua vida e de seu contexto. Maquiavel era nascido na Toscana, e trabalhou na vida pública de Florença. A Itália em sua época era uma região alvo dos interesses dos nascentes Estados absolutistas. Maquiavel era defensor da formação das milícias para a defesa das cidades-estados italianas, sobre tudo em Florença. Sua crítica maior era sobre os exércitos mercenários que não combatiam com empenho necessário, pois não existia uma identificação com a região defendida.

Segundo ADVERSE (2006), Maquiavel reconhece de imediato o caráter necessário do exército próprio e associa a política à arte militar.

O profissionalismo militar como tal não apresentaria nenhum problema para Maquiavel; visto que os exércitos profissionais do criminoso e tirano Sétimo Severo e os soldados-cidadãos pagos da última república romana eram modelos de uma força militar eficaz e bem controlada. O problema parecia estar nas forças militares mercenárias ou auxiliares, não naquelas profissionais, pagas e controladas pelas autoridades políticas (que podiam até ser, elas mesmas, autoridades militares). (LYNCH, 2006:LVI)

O resgate da experiência dos tempos passados foi interpretado por muitos pensadores contemporâneos, segundo LYNCH (2006), como equívocos de Maquiavel, associados às mudanças tecnológicas que prenunciava uma transformação definitiva da tática dos combates como o advento da artilharia. Ao contrário, o pensador italiano acreditava que o avanço tecnológico não substitui o bom soldado, mas ele era inevitável. "Para 
Maquiavel, portanto, inovações em tecnologias militares são úteis e necessárias, contudo, elas não excluem a necessidade da excelência humana" (op. cit. 2006:LVII). Maquiavel sobre a artilharia, no livro VII de A arte da guerra concluiu:

Os instrumentos com que os antigos defendiam as cidadelas eram muitos, como balista, onagros, escorpiões, arcubalistas, fundíbulos, fundas; e também eram muito os usados para o assalto, como aríetes, torres, manteletes, plúteos, víneas, foices, tartarugas. Em troca dessas coisas, hoje existe a artilharia, que serve a quem ataca e a quem se defende". (MAQUIAVEL, 2006:206)

$\mathrm{Na}$ apresentação da edição brasileira de A arte da Guerra de Maquiavel (2006), ADVERSE (2006) destaca o caráter de modernidade no pensamento de Maquiavel "encontramos uma unidade entre o poder político e o poder militar (...) além da imbricação, há uma espécie de homologia entre guerra e política" (op.cit. 2006:XII). Ora esse pensamento irá ter um impacto no cerne do pensamento clausewtziano que diz ser a "guerra uma simples continuação da política por outros meios" (CLAUSEWITZ, 2003). De acordo com LYNCH (2006), A arte da guerra é uma referencia ao pensamento militar de seu tempo, ao mesmo tempo, que às origens do próprio pensamento moderno "o pensamento militar a partir do século XVI prosseguiu com base nos fundamentos lançados por Maquiavel” (GILBERT apud LYNCH, 2006:LXIII).

Para Maquiavel, a cidadania estava associada a vida militar sendo que a última poderia esculpir os melhores cidadãos, LYNCH (2006) afirma que "a inovação de Maquiavel deve mostrar que a natureza humana pode ser aprimorada por meio da virtude militar" (op. cit 2006:LII). De certa forma é uma resposta as proposições de Vegécio, que encarava a sociedade de maneira mais determinista sendo, para ele, o homem do campo muito mais propenso a vida militar. Maquiavel pensava que a vida militar moldaria os cidadãos que defenderiam a sua soberania, assim, não sendo submetidos aos exércitos mercenários que dominavam as defesas das cidades-estados italianas. Nas palavras de Fabrizio, o condottiero de Arte da Guerra, Maquiavel realiza uma intertextualidade com Vegécio, mas adaptada a realidade do 
momento, ele responde a seguinte pergunta de COSIMO: de onde julgais melhor extrair os homens, da cidade, ou do campo?

FABRIZIO Todos os que escreveram sobre isso concordam que é melhor escolhe-los no campo, por serem homens avezados ao desconforto, criados na labuta, que tem o costume de ficar ao sol, fugir à sombra, lidar com ferro, cavar fossos, carregar peso, não ser astuciosos nem maliciosos. Mas neste assunto a minha opinião seria que, em havendo necessidade de soldados de dois tipos, a pé e a cavalo, que os peões fossem selecionados no campo, e nas cidades os montados. (MAQUIAVEL, 2006:24)

No livro V de A arte da Guerra, Maquiavel (FABRIZIO) começa o debate destacando a informação da guerra para a movimentação das tropas na época dos romanos, "deveis saber que nos exércitos romanos, de ordinário, sempre se mandavam algumas turmas de cavaleiros como especuladores do caminho (...) mandando-se à frente a cavalaria ligeira para reconhecer o terreno" (op. cit. 2006:139). Doravante, Maquiavel começa a discorrer sobre geografia da guerra. A primeira grande advertência sobre o terreno desconhecido e com matas e montanhas, que Sun Tzu chamaria de terreno capcioso, "e maior deverá ser a diligência quanto mais favorável a emboscada for o território, como o são as regiões com muitas matas e montanhas, porque as emboscadas sempre são feitas em selvas ou atrás dos montes" (op. cit. 2006:153). Com exército em marcha em terreno desconhecido o exército deve redobrar os cuidados unindo-se e mais uma vez é importante a informação do território; "e a primeira coisa que deve fazer é ter a descrição e o desenho de todo o território por onde vai passar(...), a quantidade de pessoas, as distâncias, os caminhos, os montes, os rios, os pântanos e todas as suas qualidades" (Ib. ibidem, 2006:154).

Ainda, Maquiavel expôs sobre a questão do clima e da guerra quando é questionado por BATISTA, se é melhor continuar a guerra durante o inverno, como se faz hoje, ou só travá-la no verão, sua resposta parece uma profecia, ou um conselho que pouco se leva em conta quando os diligentes não analisam as coisas com cautela, buscando sempre a dominação. FABRIZIO (MAQUIAVEL) responde: 
FABRIZIO Nada há de mais imprudente nem mais perigoso que fazer guerra durante o inverno; e a muito mais perigo está exposto a quem a faz do que quem a sofre (...). Por outro lado, nada há de mais inimigo da ordem que os terrenos ásperos ou o tempo frio e chuvoso; porque o terreno áspero não te permite espalhar teus homens como exige a disciplina, enquanto o tempo frio e chuvoso não te permite mantê-los juntos (...). No entanto deveriam ver quantos prejuízos lhes causou o hábito de guerrear durante o inverno e lembrarse de como os franceses, no ano de mil quinhentos e três, foram derrotados junto ao Garigliano pelo inverno, e não pelos espanhóis. Porque, como vos disse, quem ataca tem mais desvantagem: o mau tempo fere-o mais, por estar em casa alheia (...) (MAQUIAVEL, 2006:193194).

Esse conselho parece ter sido menosprezado por vários comandantes, ou por acreditarem excessivamente em si mesmos, ou simplesmente, por não levarem em conta este conselho como válido para os seus dias. Napoleão que dizem ter tido contato com a obra de Maquiavel deve ter lido com muita dor, esses conselhos, depois que perdeu a guerra na Rússia, num inverno considerado um dos mais rigorosos daqueles tempos. E mesmo com toda a tecnologia desenvolvida até meados do século $X X$, os alemães sofreram com o frio da Rússia e foram derrotados amargamente pelos soviéticos. O inverno e outras questões climatológicas seguiram influenciando os rumos das batalhas. No espaço marítimo a tempestade afundou uma das maiores frotas daquele momento a Armanda Invencível em 1588. Mas sobre os ventos e mares, Maquiavel se curva a Vegécio, mesmo sem citá-lo. "Sobre o mar não teria a pretensão de falar, por não ter conhecimentos sobre ele" (MAQUIAVEL, 2006:218). Esta passagem é uma clara referencia A Geografia dos Mares de Vegécio.

Nas considerações seguintes, como os outros pensadores, Maquiavel continuou a linha de ressaltar as qualidades militares do terreno para sua utilização tática em caso de guerra. O território pode ser usado para emboscadas, como já foi colocado, e como apoio em obstáculos, também em obstáculos artificiais como a fortificações de cidades ou postos avançados como é descrito no Livro VII - isto quando o exército é inferior ao do inimigo. Maquiavel ressalta a importância do sítio mais elevado e como se colocar a favor do vento, para reduzir a força de lançamento de armas de arremeço. E 
no fim do Livro VII, segundo ADVERSE (2006), Maquiavel pontua as antigas máximas(regras) da guerra que fora exposta por Vegécio em Instituições Militares:

- O que favorece o inimigo prejudica-te, e o que te favorece prejudica o inimigo.

- Na Guerra, quem for mais vigilante na observação das intenções do inimigo, e mais esforços envidar para treinar seu exército incorrerá em menores perigos e poderá contar mais com a vitória.

- Nunca leves teus soldados para uma batalha em antes confirmares a sua coragem e saberes que não têm medo e que estão ordenados; e terás prova disso quando vires que eles esperam vencer.

- Melhor será vencer o inimigo pela fome que pela espada, vitória na qual pode muito mais a fortuna que a virtude

- Nenhuma decisão é melhor do que aquela que o inimigo não conhece até que a tenhas executado.

- Na guerra, saber reconhecer a ocasião e aproveitá-la é coisa que vale mais que qualquer outra.

- A natureza gera poucos homens valentes; a indústria e o exercício os fazem em grande quantidade

- Na guerra, a disciplina pode mais que o furor.

- Dificilmente é vencido aquele que sabe conhecer suas forças e as do inimigo.

- Os bons capitães nunca se lançam à batalha se não forem compelidos pela necessidade ou convidados pela ocasião.

- Homens, espadas, dinheiro e pão são o nervo da guerra; mas, dos quatro, os dois primeiros são mais necessários, porque homens e espadas conseguem dinheiro e pão, mas pão e dinheiro não conseguem homens e espadas.

- O desarmado rico é prêmio para o soldado pobre.

- Aconselha-te com muitos sobre as coisas que deves fazer; o que depois pretendes fazer conta-o a poucos. 
- Quem confia mais na cavalaria que na infantaria ou mais na infantaria que na cavalaria, que o terreno lhe valha. (MAQUIAVEL, 2006:215;216;217).

Neste conjunto de regras o autor não descarta os métodos heterodoxos de se fazer guerra, algo que o distingue de todos os teóricos da guerra, as artimanhas, que é muito falado pelos mestres orientais, que Segundo ADVERSE (2006), Maquiavel denomina de inganno ou a dissimulação que deve ser aplicada tanto externamente, ou seja, contra o inimigo, como internamente, muitas vezes os soldados não devem conhecer quais as intenções do comandante e a verdadeira situação do front de combate. No livro IV de A arte da guerra, FABRIZIO (Maquiavel) fala da importância da retórica para persuadir e motivar os seus soldados a fazerem 0 que realmente deseja:

Lede a vida de Alexandre Magno e vereis quantas vezes foi preciso discursar e falar publicamente ao exército; não fosse isso, depois que seu exército se tornou rico com o fruto das pilhagens, ele jamais o teria conduzido para os desertos da Arábia e para Índia com tanto desconforto e incômodo; (op. cit. 2006:136)

Com isso Maquiavel conseguiu unir, segundo LYNCH (2006) o pragmatismo técnico da arte da guerra ocidental com a oriental, coisa que é mais difícil de acontecer, como veremos adiante, no pensamento clausewitziano, "o exército de Maquiavel amalgama elementos cruciais de exércitos não pertencentes ao Ocidente com elementos essências dos antigos exércitos romanos e gregos" (op. cit. 2006: LXXIII).

Depois dos grandes erros cometidos pelos Estados Unidos no Vietnã, ao utilizar o modelo de guerra total clausewtziano ou "ocidental", atualmente, sua estratégia é realizar guerras curtas destinadas a atingir os pontos fracos do inimigo, como foi feito na Guerra do Golfo Pérsico, na Intervenção em Kosovo, e no Afeganistão. Embora seja bem provável que na administração de George W. Bush Jr., a política estratégica dos Estados Unidos tenha se voltado às origens clausewitziana ao se debruçar em uma guerra de conquista, o que pode ter sido fatal para os cofres e para saúde 
precária de sua economia. Hoje, a atual administração, Barack H. Obama prega uma guerra a partir do Afeganistão - e não uma mudança na forma em que os Estados Unidos estão fazendo a guerra - o que reduziria os esforços no Iraque, mas a medida que o tempo passa os Estados Unidos se afundam em terreno profundo e capcioso, e os gastos com a guerra, ao que parece, ainda não diminuíram, nem em plena a uma das maiores crises econômicas da história do capitalismo que afetam de maneira dramática a sua economia.

\section{A geografia em Clausewitz: um olhar cientificista sobre a guerra}

A guerra será discutida com um tom científico, depois das guerras napoleônicas, e Da Guerra (Vom Krieg) de Carl von Clausewitz foi uma obra com pretensões científicas, dada pelo próprio autor, mas que têm um cunho mais ideológico. Seus leitores muitas vezes o interpretaram como um saber científico aplicável e fizeram uma catástrofe que resultou em guerras catastróficas.

Uma espécie de manual dos imperadores modernos, Da Guerra foi publicada após a morte do autor em 1832. Ele viveu entre o século XVIII e XIX, um período de transição histórica, contudo existe em seu trabalho um caráter dual em que a ordem internacional de Vestfália (1648-1815) chegava ao fim e da Santa Aliança (1815-1914) começava a se estruturar.

De um lado encontrava-se o sistema internacional europeu de 1648-1789, que Clausewitz olhou sob uma elucidativa perspectiva histórica. Do outro, o sistema internacional europeu de 1815-1914, do qual Clausewitz se tornou profeta (RAPOPORT, 1996: XVII)

Este caráter dual se encontra em dois conceitos que são antagônicos, a dialética clausewtiziana entre a: ofensiva tática ligada mais aos primeiros capítulos e que dá a fama ao autor de maldito entre os pensadores do século XIX, chamado por Liddell Hart de "Mahdi das massas e do massacre mútuo" (apud ARON, 1996:8); e a defensiva estratégica que coloca o uso fundamental dos fatores geográficos. O problema, neste caso foi má interpretação desta fórmula dialética pelos generais e líderes do Estado Maior, que consideraram mais a questão da ofensiva tática, do maior número, das 
melhores armas, para subjugar o inimigo e levá-lo a destruição total, ou ao desarmamento. Se estes tivessem lido melhor o livro se atentariam a perceber que é possível realizar uma defesa usando os aspectos mais variáveis, com menor número de pessoas. Clausewitz, é importante que se destaque, mesmo falando de estratégia, pondera sempre a luz da evolução tática que muda a forma de se lutar incorporando territórios onde antes não se lutava por falta de conhecimento, técnica e tecnologia. Os princípios do Congresso de Viena iriam redesenhar o mapa político europeu. Segundo RAPOPORT (1996), Clausewitz viveu entre o século XVIII e XIX, tal qual Beethoven, portanto podemos observar em seu trabalho um caráter dual, assim como no caso do compositor, onde a ordem internacional de Vestfália (1648-1815) estava chegando ao fim e a ordem da Santa Aliança (1815-1914) começava a se estruturar, portanto esta foi uma época de transição histórica onde "as suposições ideológicas eram tão importantes quanto os fatos consumados" (Ib. ibidem, 1996: XIX). Assim, para Clausewitz, o Estado Soberano era análise de um estado personificado que ficou bem caracterizado pela frase do rei francês Luis XIV - "O Estado sou eu". Aspecto de um Estado que vigorou até aquele período:

\begin{abstract}
Este sistema internacional vinha funcionando desde 1648. O tratado de Vestfália (...) no final da Guerra dos Trinta Anos a idéia do Estado soberano sob autoridade secular ficou firmemente estabelecida no pensamento político europeu. Simultaneamente, a noção de autoridade supranacional, que dominara a Idade Média, recuou para obscuridade. (RAPOPORT, 1996: XIX)
\end{abstract}

A Ordem da Santa Aliança, abordada nos estudos de Relações Internacionais, foi um sistema internacional ${ }^{12}$ demarcado historicamente por compreender o período entre duas guerras de dimensões catastróficas na Europa. Trata-se das guerras napoleônicas que perduraram do final do século XVIII até o Congresso de Viena de 1815, e da Primeira Grande Guerra Mundial, de 1914-1919, que, por sua vez, foram responsáveis por importantes transformações da configuração e das relações geográficas do nosso globo. Dois princípios foram usados para reconstruir a Europa depois das guerras

12 ARON, R. (1962:153): Paz e Guerra entre as nações. Um "Sistema internacional é o conjunto constituído pelas unidades políticas que mantém relações regulares entre si e que são suscetíveis de entrar numa guerra geral". 
napoleônicas: a preservação do equilíbrio político das potências e a restauração das antigas dinastias derrubadas por Napoleão Bonaparte.

As guerras que marcaram a mudança da Ordem Internacional no século XIX eram muito semelhantes, em termos práticos, com as guerras que marcaram o século XVII e XVIII. No entanto, o patriotismo é um novo elemento trazido das guerras Napoleônicas depois disso as guerras serão travadas por motivos nacionais. Por exemplo, muitos soldados franceses sentiam que levavam consigo a Revolução Francesa para povos que estavam sobre o julgo dinástico. Este impulso bélico manteve um alto grau bélico do exército de Napoleão. Assim, a importância das guerras napoleônicas foi levar a condição do Estado Nacional e por fim ao Estado Absolutista, portanto a partir disso o nacionalismo passa a ter enorme importância nas Relações Internacionais.

O conceito de Estado foi intensamente teorizado e desenvolvido neste longo século XIX; para Clausewitz o Estado era como uma pessoa personificada na figura do rei. "Os agentes, no paradigma clausewitziano, das relações internacionais são, Estados soberanos que, para todos os efeitos práticos, podem ser considerados como pessoas". (RAPOPORT, 1996: XVII). O Estado personificado foi uma visão que durante o século XIX se transformou no conceito de Estado-Territorial; de fato, os estados territoriais começaram a fazer mais sentido a partir deste momento, pois o Congresso de Viena teve um embasamento de um conhecimento geográfico, que era cada vez mais preciso do que fora em tratados anteriores e, os Estados começavam a ser definidos pelos seus territórios, tanto na Europa como no resto do mundo, vide os processos de independência na América Latina ao longo do século XIX.

Mas quem foi Clausewitz? Segundo KEEGAN (1995), Clausewitz era oficial de um regimento prussiano. Um regimento é uma unidade militar tradicionalmente comandada por um Coronel. "O regimento - semanticamente, a palavra liga-se ao conceito de governo - foi um expediente para assegurar ao Estado o controle das forças armadas" (KEEGAN, 1995:29). Dependendo da missão, país de origem e composição, um regimento moderno tem uma dimensão similar a uma brigada. Essencialmente a diferença atual entre um Regimento e uma brigada é que esta inclui subunidades de várias armas e serviços, enquanto que o primeiro inclui normalmente forças de uma única arma. 
Segundo KEEGAN (1995), os regimentos têm origem nos exércitos mercenários que com o advento da pólvora e artilharia substituíram os exércitos senhoriais. "O bombardeio por artilharia móvel, uma nova arma utilizada com êxito pela primeira vez por Carlos VIII, sucessor de Carlos VII, anunciou o fim do desafio à autoridade real dos senhores de castelos" (KEEGAN, 1995:30). Esses regimentos começam a fazer parte da realidade e da paisagem européia, um processo que teve início em 1490 com Carlos VII e passam se tornar instituições reais e mais tarde instituições nacionais. Aos poucos os regimentos começaram a se parecer mais com milícias e os Coronéis eram responsáveis por preparar e administrar as unidades militares e - Estado pagava uma quantia do tesouro real para sustentá-lo, os descendentes desses coronéis "ficavam contentes ao receber coronelatos da infantaria por favor real" (Ib. Ibdem, 1995:30)

\begin{abstract}
Esses novos regimentos adquiriram rapidamente um caráter diferente daquele dos bandos mercenários ao final do feudalismo e das guerras religiosas (época vivenciada por Maquiavel), que geralmente debandavam quando os fundos secavam (...). Eles se tornaram instituições reais - posteriormente nacionais permanetes, gannhando amiúde quartéis-generais fixos numa cidade de província, recrutando na região circunvizinha e retirando seus oficiais de uma coterie de famílias aristocráticas. O 34ํㅡㄹ Regimento de Infantaria da Prússia, para qual Clausetiz entrou em 1792, aos onze anos de idade, era exatamente um regimento desse tipo. Fundado em 1720. (KEEGAN, 1995:30).
\end{abstract}

Grande parte dos estudos feitos sobre $D a$ Guerra foram desenvolvidos sob a ótica das Ciências Políticas ou dos estrategistas militares e não da geografia aplicada à guerra o que também está na obra de Clausewitz. Até o livro $V$ os estudos são muito minuciosos e a ciência política é bem específica ao tratá-los melhor do que os Livros VI e VII, principalmente. Este fato acontece em função de que Clausewitz nestes dois livros pensa na geografia do teatro da guerra, portanto pensa na estratégia da guerra e não apenas na batalha em si.

Clausewitz, ao pensar sobre a guerra, rechaça a idéia de fazer mais um tratado de arte da guerra, na verdade, seu propósito é ver a guerra a partir do olhar da ciência, como um conhecimento investigativo, isto porque sua 
formação militar atrela seu pensamento totalmente à guerra, pois para Clausewitz em Da Guerra, "a guerra é um ato de violência destinado a forçar o adversário a submeter-se à nossa vontade" (op. cit., 2003:7). Em Arte e ciência da guerra (1972), o pensador prussiano se opõe de maneira impactante aos pensadores marciais orientais dizendo que não existe maneira de desarmar nosso inimigo e assim forçá-lo a nossa vontade sem guerra. Portanto, para Clausewitz não importa mais as artes marciais e sim a ciência da guerra, "a arte pertence ao domínio da criação, da produção, mas quando se trata das coisas de investigação e saber a ciência é soberana" (op.cit. 1972:136).

Talvez as almas filantrópicas dêem a idéia de que existe alguma maneira, alguma forma artificiosa de desarmar e vencer o adversário sem demasiado derramamento de sangue e que isto é a verdadeira arte da guerra. Por mais desejável que pareça, tal idéia não deixa de constituir-se num erro; um erro que convém eliminar. (CLAUSEWITZ, 1972:10) ${ }^{13}$.

Projetando o desdobramento do pensamento do prussiano, sua teoria mostrou como idéias podem ser demasiadamente influentes em nosso mundo podendo inclusive alterá-lo. A Europa no início do século XIX vivenciava uma política de desarmamento e no fim desse mesmo século, os países se atiravam numa corrida armamentista levando a Europa ao maior massacre humano da história da humanidade sendo, Clausewitz, considerado "O pai ideológico da Primeira Grande Guerra Mundial” (KEEGAN, 1995:39). O continente europeu - na época em que Clausewitz escreveu os manuscritos "Da Guerra" - em 1818 era completamente exaurido pelas guerras napoleônicas, conhecidas pelos europeus daquele momento como a "Grande Guerra”. A Guerra, na teoria de Clausewitz, deveria servir apenas a si mesma, além de ser uma continuação da política por outros meios, isto fez com que durante o século XIX - sobretudo a partir da primeira metade - as potências européias voltassem a se armar, sendo a Alemanha a principal artífice deste processo. "No século XIX, a Prússia foi efetivamente tomada por regimentos;

\footnotetext{
${ }^{13}$ CLAUSEWITZ, C. - Arte y ciencia de la guerra, versão em espanhol; Ramon Orzamazábal: "Tal vez las almas filantrópicas den en la idea de que existe alguna manera, alguna forma artificiosa de desarmar y vencer al adversario sin demasiada efusión de sangre, y que a eso tiendel el verdadero arte de la guerra. Por más deseable que ello parezca, tal idea no deja de constituir um error; um error que conviene eliminar". (op. cit, 1974:10)
} 
em 1831, havia apenas quarenta deles, mas em 1871 havia mais de cem" (Ib. ibidem, 1995:37).

Entre a caneta e a espada, Clausewitz não pensaria duas vezes. Se para submeter o inimigo usa-se a política e a guerra é tida como uma continuação da política e servi apenas a si mesma, e para submetê-lo eu deva desarmar meu inimigo, portanto quem for mais sagaz, faz a guerra. É por esse caminho que os preceitos Clausewitz levam o seu leitor. Segundo RAPOPORT (2003), Clausewitz encara a guerra como um instrumento racional da política nacional, as palavras 'racional', 'instrumental' e 'nacional' são conceitos-chave do seu paradigma: a decisão de empreender a guerra deveria ser racional, no sentido de que deveria ser baseada numa avaliação de custos e lucros da guerra; a guerra deveria ser instrumental, isto é, deveria ser empreendida com vista a alcançar-se um objetivo, e nunca por si própria; a guerra 'deveria' ser nacional e para que o seu objetivo fosse satisfazer os interesses de um Estado nacional e para que justifique que todo o esforço de uma nação seja mobilizado a serviço do objetivo militar. O pensamento de Clausewitz quando está entre fazer a guerra por objetivos militares e não fazer guerra por fazer; ele concluí, que o mais interessante é fazer a guerra, por que em seu pensamento não existe o fato de não existir a guerra.

A militarização do Estado operou-se com especial rapidez na Prússia e com ela a cristalização do modelo clausewitziano de Estado nacional (...) Outra forma encontrada era alcançando fáceis vitórias militares. Estas foram obtidas nas curtas e decisivas guerras contra a Dinamarca (1864), a Áustria (1866) e a França (1870). Com estabelecimento do Império Germânico, em 1871, o Estado clausewitziano tornou-se quase uma realidade sob a forma da Alemanha imperial. (RAPOPORT, 2003:XVII)

A guerra no pensamento de Clausewitz, segundo KEEGAN (1995), é algo definido e travado por convenções, hierarquias, disciplina, formas e principalmente o que deve permear a guerra é o racional, o seu pensamento buscava uma teoria da guerra, ou seja, a guerra não fugia de certa racionalidade. Esse pensamento é compreendido se entendemos a formação regimental prussiana do século XVIII que fora submetido Clausewitz. Então os métodos heterodoxos, que são conhecidos como as artimanhas, e estão no 
pensamento de todos que falaram de guerra até então, não são idealizados pelo prussiano, para ele deve-se fazer a guerra civilizada, o que é um grande paradoxo quando comparamos sua teoria à realidade, ora isto só funcionaria se combinado com o inimigo as "regras" do combate antes da guerra, o que na realidade é algo improvável.

É mas do que necessário contemplar os fatores geográficos em sua obra, para que se estabeleça uma relação entre o desenvolvimento de suas estratégias que, de certa forma, estão subordinadas aos fatores geográficos (relevo, vegetação, hidrografia, clima), na qual ele dedica grande parte de seu esforço intelectual (Livro VI - "A defesa", Livro VII - "O ataque" e Livro VIII - "O plano de guerra").

A segunda parte de sua obra é justamente um aporte teórico para a Geografia Militar, bem característico de um estudo oriundo dos regimentos de infantaria. Pois para infantaria o conhecimento do campo de batalha e como melhor tirar proveito, é a diferença entre a vida e a morte.

\begin{abstract}
Que se queira ou não, ao passarmos dos livros III, IV e V ao livro VI respiramos um ar diferente. Os livros III e IV estão cheios de frases através das quais Liddell Hart ilustra com inteira liberdade sua tese do "Mahdi das massas e do massacre mútuo". Ele dá a impressão de exaltar a batalha, a batalha sangrenta, a grandeza destes afrontamentos e o culto do chefe supremo, mestre de suas emoções e clarividente em meio a tempestade. Em compensação, o livro VI enumera vantagens de que beneficia aquele que se encontra política e militarmente na defensiva. (ARON, 1986:12)
\end{abstract}

Concluído este breve histórico político do pensamento da guerra em Clausewitz, faz-se, doravante, uma análise de sua geografia militar. Os capítulos mais elucidativos, caminhando por esta senda, são: livro VI - A defesa (capítulos: XV- A defesa em montanha; XVIII -A defesa dos riachos e rios; XX -A defesa dos pântanos e as inundações; XXI -A defesa das florestas); Livro VII- $O$ ataque (capítulos: A travessias dos rios; IX ataque das posições defensivas; XI- ataque de uma cadeia de montanhas; XIV- Ataque dos terrenos pantanosos, inundações florestas; XV- Ataque num teatro de guerra no caso em que se procure uma decisão; XVI- Ataque de um teatro de guerra sem decisão). Nestes pontos, nos mais técnicos da guerra e que são classificados 
como pontos da geografia militar, o prussiano pensa até de forma mais heterodoxa bem no estilo dos antigos e da própria geografia militar.

Toda concepção teórica de Clausewitz gira em torno da questão do território e a partir do concreto que faz suas análises da ação militar, em todos os capítulos ele ressalta a importância do espaço. Por exemplo, no livro I, capítulo III - O gênio da guerra: a guerra, para o prussiano, portanto, é uma relação com o lugar e o terreno da sua atividade uma notável particularidade e, assim considera um excelente general aquele que entre suas varias capacidades conseguem "encontrar no espaço em que opera um parceiro de ação em que está empenhado" (op. cit. 2003:66).

A respeito das concepções estratégicas, no livro III, capítulo II Os elementos da estratégia, Clausewitz afirma: "Pode-se, portanto dividir em elementos de diferente natureza as causas que, em estratégia, determinam o recurso ao combate, a saber: os elementos morais, físicos, matemáticos, geográficos e estatísticos" (op. cit. 2003:181).

Contudo, a partir do livro $\mathrm{VI}$, especialmente nos capítulos: $\mathrm{XV}$, XVI, XVII - a defesa em montanhas; e, no capítulo XI do Livro VII - Ataque de uma cadeia de montanhas - Clausewitz começa a desenvolver uma geografia militar específica.

Afirmando que o relevo montanhoso influencia muito a condução da guerra, pois, "introduz na ação um princípio de retardamento, ela concerne sobretudo à defesa", mas, o prussiano continua dizendo que o terreno montanhoso não era considerado para batalha, pelo menos até meados do século XVIII pois, a condição técnica de combate, até aquele período, era mais semelhante a lutas senhoriais do que foram as batalhas nas guerras napoleônicas:

Antes da Guerra dos Trinta Anos, na época da ordem de batalha profunda, da cavalaria numerosa, das armas de fogo primitivas, e etc., a utilização de grandes obstáculos do terreno era inteiramente excepcional, e a verdadeira defesa em montanha, quase impossível, pelo menos com tropas regulares. Só quando a infantaria e as suas armas de fogo se tornaram o essencial do exército é que as montanhas e vales foram tomados em consideração. (op. cit. 2003:570) 
Portanto, ele destaca a condição facilitadora das posturas defensivas em montanhas e pondera que com as mudanças táticas trazida pelo desenvolvimento das infantarias francesas - que eram: numerosas, rápidas e bem organizadas e com a dinâmica movimentação de artilharias em campo, se mostraram uma revolução nas questões táticas - as montanhas não eram mais um terreno a se evitar completamente, mas que deveria haver um cuidado, uma organização e movimentação das tropas distintas daquelas usadas em terrenos mais favoráveis ao confronto. "Como os exércitos são cada vez mais numerosos desde a Idade Média, a tática evoluiu de tal modo que o terreno montanhoso se integrou na ação militar" (op. cit. 2003:571).

É sobre essa fraqueza que o assaltante faz dirigir os seus golpes. O assalto de um ponto laçando com uma força concentrada, portanto muito superior, engendra uma resistência muito violenta em relação a esse ponto preciso, mas insignificante em relação ao conjunto. Uma vez quebrada essa resistência, a linha é rompida e o objeto do ataque é atingido. (op.cit. 2003:575)

No caso do Rio de Janeiro, por exemplo, com o seu território montanhoso e com seus problemas com as organizações criminosas, milícias entre outras forças não estatais, ainda vivemos a Idade Média! A contravenção e as maiores barbáries que ocorrem nos morros, pois o Estado não esta presente, acontecem porque são favorecidos pela condição montanhosa do terreno, pelo armamento bélico pesado, e pela ocupação densa e não organizada, estes são argumentos válidos, mas, não são totalmente verdadeiros.

Por outro lado, o que existe é uma corrupção tão grande das organizações estatais e forças estatais que não há uma "vontade" política para se resolver a questão. Mas, quando foi necessária a ação do exército nos morros os pontos estratégicos do narcotráfico foram controlados e depois, com uma negociação nebulosa entre Estado e narcotraficantes, foram devolvidos aos narcotraficantes e o exército se retirou.

O caso mais grave de ataque a um quartel do Exército ocorreu em março de 2006, com o roubo de 10 fuzis e 1 pistola de uma unidade em São Cristóvão, no Rio. Como resposta, as Forças Armadas iniciaram a Operação 
Cerco Total e subiram em 12 favelas, em busca dos criminosos. Doze dias depois do roubo, em 14 de março, as armas foram achadas num matagal entre os Morros do Vidigal e da Rocinha. O Exército admitiu - e depois negou - que a localização das armas foi revelada por traficantes - a presença de 1.200 militares nas favelas estava prejudicando a venda de drogas. (Estado de São Paulo, Terça-Feira, 10 de Março de 2009).

É verdade que o terreno montanhoso favorece os narcotraficantes e a concentração de poder das organizações criminosas cariocas, mas ficou claro, com ação do exército - que é bastante discutível se deve agir ou não em áreas não fronteiriças - que é perfeitamente possível controlar o crime na cidade do Rio de Janeiro, não com caverões que são verdadeiras maquinas de extermínio da população, mas com uma tática adequada.

Esta, antes de qualquer objeção, é uma questão social. A ação militar, ou de outras forças estatais, são válidas, por que a situação é calamitosa, declarado por muitos jornais, até os mais conservadores, como estado de guerra civil, como foi no caso da ocupação de quase um ano em 2007 do morro da Providência. Mas nada disso resultará em bem algum, pois a verdadeira mudança só acontecerá quando o Estado criar uma estrutura mais organizada e com os seus serviços se fixando no centro destas comunidades, que no caso dos morros estão nas partes mais altas, assim do centro para fora acontecerá uma verdadeira mudança nestas regiões problemáticas da sociedade brasileira. A transformação social deve ser feita de dentro para fora e não ao contrário, como é o caso da ação invasiva, esta por sua vez, só deve ser feita em casos de emergência.

Mais adiante, no livro VI, capítulo XVIII e XIX - A defesa dos riachos e rios - o prussiano afirma: que como a montanha os territórios marcados pelos rios favorecem a defesa. "Qualquer rio importante, com seu vale principal e adjacentes, forma um conjunto de obstáculos muito importantes, de um modo geral favorável à defesa" (op.cit. 2003:613). Uma região com uma elevada densidade de drenagem tem por ser um grande obstáculo as operações militares favorecendo a defesa, essa se principalmente tiver fortificações em pontos estratégicos para impedir o fluxo de tropas pelo próprio rio. Uma travessia de rios que funcionam como fronteira é bem delicada, pois o inimigo que o faz, conseqüentemente, perde sua retaguarda e 
pode sofrer por assaltos sendo divido, ou cercado e, assim, massacrado pela defesa sem ter um plano de fuga. Clausewitz exemplifica com o caso da Prússia na Guerra dos Sete Anos e a defesa pelos rios Elba e Oder:

Basta uma rápida análise sobre o desenvolvimento da
Guerra dos Sete Anos para nos convencermos de que o
rio Oder e o rio Elba foram muito úteis a Frederico, o
Grande, na defesa do seu teatro de guerra, ou seja,
Silésia, da Saxônia e de Brandemburgo e por
conseqüência prejudicavam os austríacos e russos, que
queriam conquistar estas províncias, ainda que não se
tenha processado uma verdadeira defesa desses riachos
durante toda a Guerra dos Sete Anos. (op. cit. 2003:614).

Sobre a defesa dos pântanos e as inundações, no livro VI, capítulo XX, Clausewitz diz que são teatros que favorecem a defesa mais uma vez, assim como os rios e riachos, mas com alguma particularidades. "A primeira e principal é que, com exceção dos diques, um pântano é completamente impraticável para infantaria, e é, portanto, mais difícil de atravessar que qualquer outro riacho". (op. cit. 2003:617). Já as inundações, "como meio de defesa e como fenômeno natural aparentam-se incontestavelmente aos lodaçais" (Ib. ibidem, 2003:619). Clausewitz aponta dois exemplos sobre o mesmo país, a Holanda, que ao fechar e abrir as comportas de seus diques pode pôr o país inteiro em baixo d'água, esses exemplos foram importantes nas campanhas de 1672 e 1787 com a França e Alemanha respectivamente.

Na primeira vez, com a França, segundo Clausewitz, uma força de 25.000 a 30.000 soldados conseguiu conter o conde de Luxemburgo e rechaçaram o inimigo. No segundo momento, com a Alemanha mais preparada, o duque de Brunswick, "graças a um dispositivo tático muito hábil, bem adaptado às condições locais" (Ib. ibidem 2003:621) quebrou a linha de defesa, é claro que a conjuntura política e o desenvolvimento tático eram bem diferentes nas duas épocas, mas o exemplo é formidável.

No livro VI, capítulo XXI - A defesa das florestas - Clausewitz destaca a importância de evitar os terrenos florestados devido à difícil visibilidade: "é preciso deixar as florestas para trás ou evitá-la a todo custo. Mais do que o assaltante, o defensor tem a necessidade de uma visão livre" 
(op. cit. 2003:626). É bom não esquecer o fato que a guerra para Clausewitz é quase uma disputa entre cavalheiros com regras, moral, hierarquias. A guerrilha, por exemplo, que se beneficiaria de maneira, evidente de um terreno florestado não é comentado pelo pensador prussiano.

Concluindo, no livro VII - O ataque - o prussiano, no capítulo VIII a travessia do rio, nos chama atenção para o valor da batalha, um rio deve ser defendido para enfraquecer o assaltante e não para realizar a batalha decisiva "um rio pode alcançar um grande valor desde que não se procure uma grande decisão" (op. cit. 2003:756). Mas Clausewitz continua, "mas se devemos contar com ela dado o número superior ou a energia do inimigo, e se a operação foi mal iniciada, esta pode ganhar um valor positivo para o assaltante" (Ib. ibidem, 2003:756).

Embora o pensamento de Da Guerra tenha um caráter dual: defensiva estratégica e ofensiva tática. A conclusão é que a segunda se sobrepõe a primeira diante da superioridade numérica e da intensidade do combate. Portanto, para Clausewitz, a defensiva estratégica deve ser realizada quando não há mais solução no combate, ou para enfraquecer o inimigo, que no jargão militar se traduz como ganhar tempo e nunca esta deve ser acreditada como o centro das atividades, para o prussiano, a melhor defesa é o ataque. A travessia do canal da mancha pelas forças aliadas, o dia "D", reflete bem o que Clausewitz classificaria como uma ofensiva tática bem sucedida. As forças aliadas tinham uma superioridade numérica e devido à intensidade do ataque destruiu as forças de defesa alemãs nas praias da Normandia, que eram consideradas intransponíveis, mesmo que as baixas tenham sido enormes o objetivo fora alcançado; destruir as forças de defesa alemã no teatro ocidental da guerra e fazer frente a União Soviética na frente oriental.

Por conseguinte, o assaltante superior em número e capaz de sérios golpes pode fazer sempre uma demonstração sobre um ponto e atravessar outro, depois fazer virar em seu proveito, graças à superioridade numérica e ao seu impulso ininterrupto, as primeiras circunstâncias deploráveis que tiver encontrado no recontro; porquanto pode consegui-lo graças à sua superioridade numérica. (CLAUSEWITZ, 2003:757) 
Segundo Liddell Hart, pensador britânico da guerra moderna, o pensamento da guerra ofensiva, muito influenciado pelas guerras napoleônicas corre sobre dois equívocos: o primeiro é a superestima pelos números; e o segundo é o menosprezo pela manobra. Ora é bem certo que Clausewitz, como foi analisado neste debate, considera o valor da defensiva estratégica que se pauta nas vantagens trazida pelo território, mas a sua conclusão é bem clara, a ofensiva tática supera os obstáculos de uma política totalmente defensiva. Liddell Hart discorre que é estranho que Clausewitz não tenha percebido nas conseqüências do pós-guerra diante de uma política pautada num exército de massas, tal como foi com a França de Napoleão que de maior potência se reduziu a mera força secundária no continente europeu. 


\section{CAPÍTULO 4 \\ O NOVO IMPERIALISMO E SUA NOVA GEOGRAFIA MILITAR: A SUA LOGÍSTICA, ESTRATÉGIA E INTELIGÊNCIA.}

\section{Introdução}

Existe uma questão que deve ser esclarecida neste ponto da discussão: Por que a disciplina geografia militar foi deixada de lado frente a outras disciplinas e até mesmo outros conceitos, não só no Brasil? Podemos estabelecer alguns pontos para responder esta questão como se deve. O título deste capítulo dá um sinal de respostas que deixarão as coisas mais claras, como um antigo sutra oriental que pretende ser uma frase autoexplicativa e direta. A nova geografia militar é estabelecida por um tripé básico: a logística, quando os elementos são mensurados, e isto requer um levantamento minucioso; a estratégia, quando a direção dos movimentos são coordenadas; e a inteligência, presente na escolha das determinadas direções, podendo ponderar as condições da logística e estratégia, mas sobretudo, guiando a logística e a estratégia numa direção específica, assim podemos falar então de geopolítica.

O fracasso da linha Maginot, fortificação francesa na fronteira com a Alemanha construída no final do período entre guerras(1919-1939), talvez seja o marco do fim da antiga geografia militar, uma geografia até mesmo mais topográfica e presente de antigos dogmas sobre a tática militar, como aqueles que dizem que as montanhas e os pântanos são terrenos intransponíveis. Entretanto, no mesmo conflito podemos apontar o surgimento de uma nova geografia militar representado por duas batalhas e por dois megaestados: primeiro, pela a Batalha de Stalingrado, quando as tropas alemãs foram rechaçadas, numa estratégia defensiva e bem coordenada de retirada em massa e cerco ao inimigo cansado, a geografia foi fundamental nas considerações desta estratégia. Essa nova geografia militar deve considerar e ponderar os fatores geográficos; e, segundo, não podemos desconsiderar o exemplo da grande Batalha da Normandia, que coordenou, de maneira estrondosa, a travessia do canal da mancha, numa área muito bem protegida pelos alemães, o dia "D" deve ser considerado outro grande marco para nova 
geografia militar, pois os fatores geográficos foram ponderados, mas os obstáculos naturais foram transpostos por um bom planejamento e, por uma boa engenharia militar. Portanto temos o surgimento de duas escolas: a soviética e a americana. Analisaremos a segunda escola, visto que o conceito soviético não faz mais aquele sentido que outrora fizera. E, também, é bem verdade que temos muito mais acesso a bibliografia da escola estadunidense 0 que torna a presente análise mais segura.

Segundo Gilewitch (2003), nos Estados Unidos a primeira demanda formal por geografia militar foi a Primeira Guerra Mundial. O foco das análises os aspectos físicos do território, com um cuidado particular para aplicação dos princípios da geografia para resolver desafios militares em época de guerra. Douglas W. Johnson publicou dois trabalhos chave durante este período. Topography and Strategy in the War (JOHNSON, 1918) e o mais amplo e reconhecido trabalho do período, Battlefields of the World War, Western and Southern Fronts: A Study in Military Geography (JOHNSON, 1922). Com final da guerra a utilidade da geografia para resolver problemas de guerra foi bem compreendida nos Estados Unidos.

A importância da geografia militar cresceu durante a Segunda Guerra Mundial. Esta guerra global destacou a necessidade por uma geografia regional nos Estados Unidos "Exemplos de inúmeros trabalhos sobre os fatores geográficos são numerosos neste período" (JACKMAN, 1962 apud GILEWITCH, 2003:7). A necessidade de se conhecer a geografia regional veio de encontro com o curso da grande guerra. A geografia militar progrediu além da coleta de dados básicos, para produção de uma inteligência sobre os aspectos físicos e humanos do território. Esses esforços culminaram em Joint Army and Navy Intelligence Study (JANIS), "que eram estudos de geografia regional de um teatro de guerra específico" (PALKA, 2001 apud GILEWITCH, 2003:7). A geografia militar foi muito ampliada neste período, pelo menos enquanto durou o conflito.

De acordo com Gilewitch (2003), a Guerra do Vietnã foi uma ferramenta devastadora na popularidade e na contribuição da geografia militar, e sua reputação na academia foi decaindo. Uma parte considerável da sociedade estadunidense não estava de acordo com os esforços de guerra e universidades, faculdades e professores começaram a desvincular a 
associação entre ciência militar e geografia, por ser desprestigiosa e obscura. Durante e depois do conflito na Indochina, a geografia militar foi quase esquecida no meio acadêmico, particularmente a partir deste momento a associação entre a geografia e a ciência militar nos Estados Unidos foi rompida.

Esta condição de ruptura, segundo Gilewitch (2003), continuou até o fim da União Soviética. Apesar da importância colossal da geografia na Guerra do Golfo (1991), este conflito não contribuiu significantemente para o ressurgimento deste campo científico, mas o fim da bipolaridade da Guerra Fria pode ter sido mais importante. As mudanças na situação estratégica causaram mudanças dramáticas na estrutura, no tamanho e no posicionamento das Forças Armadas dos EUA no mundo e mostraram como seriam os novos tipos de combate. Os Estados Unidos criaram uma maneira de envolver outras nações em tempos de paz e em conflitos pontuais que se chamou Military Operation Other Than War (MOOTW) - a tradução literal é Operação Militar Diferente de Guerra - por todos os lugares do planeta. Em oito anos entre 1989 e 1997, de acordo com Gilewitch (2003), por exemplo, as Forças Armadas dos EUA participaram de 45 MOOTW. A importância deste tipo de operação em um novo ambiente geopolítico requisitou uma nova demanda pela geografia militar nos Estados Unidos. Segue a definição dada ao MOOTW pela globalsecurity, para maiores esclarecimentos:

Quando os instrumentos nacionais de poder são inviáveis para atingir os objetivos nacionais ou proteger qualquer outro interesse nacional, os Estados Unidos como nação líder deverá conduzir em larga escala operações de combates em conjunto para atingir os objetivos nacionais e proteger os interesses, estando os Estados Unidos em tempo de guerra. ${ }^{14}$

O objetivo do MOOTW é evitar a guerra, resolver conflitos, promover a paz e dar apoio as autoridades civis para resolverem as crises domésticas. O MOOTW pode

14 In: http://www.globalsecurity.org/military/library/policy/army/fm/100-7/f1007 13.htm, visitado no dia 4 de janeiro de 2010 - When instruments of national power are unable to achieve national objectives or protect national interests any other way, the US national leadership may decide to conduct large-scale, sustained combat operations to achieve national objectives or protect national interests, placing the United States in a wartime state. 
envolver elementos de ambos, do combate ou do nãocombate, operações de paz ou de guerra. ${ }^{15}$

Todas operações militares são dirigidas pelas considerações políticas. Entretanto, o MOOTW possibilita previnir ou limitar as hostilidades em potencial. Com o MOOTW, as considerações políticas permeiam todos os níveis e o aspecto militar não fica como o principal. Em guerra o objetivo do MOOTW é alcançar os objetivos nacionais mais rápidos o possível e concluir as operações militares em termos favoráveis para os Estados Unidos e seus aliados. ${ }^{16}$

No meio acadêmico dos Estados Unidos, um dos mais eminentes precursores da Nova Geografia Militar foram Palka e Galgano (2000), responsáveis por expandir o escopo da geografia militar e encorajar os trabalhos nesta área, que em tempos onde os conflitos parecem ser mais regionais, possuem, de fato, repercussões da expressão do jogo pelo poder mundial. Hoje, a geografia militar estadunidense esta ressurgindo. Com as mudanças nas relações internacionais, fim da bipolaridade da Guerra Fria, Guerra do Golfo Pérsico (1991), a intervenção em Kosovo (1999), os recentes ataques terroristas aos Estados Unidos (2001), coalizões de ataques ao Afeganistão e ao Iraque (2001), tudo isto, tem aumentado o interesse das pesquisas sobre a geografia militar na virada do século XXI. As recentes publicações nesta área exemplificam o ressurgimento desta disciplina em universidades americanas (COLLINS, 1998; UNDERWOOD and GUTH, 1998; WINTERS, GALLOWAY et all, 1998; PALKA and GALGANO, 2000; ETHLEN and HARMON, 2001; DOYLE and BENNETT, 2002).

15 In: http://www.globalsecurity.org/military/library/policy/army/fm/100-7/f1007 13.htm, visitado no dia 4 de janeiro de 2010 - MOOTW focus on deterring war, resolving conflict, promoting peace, and supporting civil authorities in response to domestic crises. MOOTW may involve elements of both combat and noncombat operations in peacetime, conflict, and war situations

16 In: http:/www.globalsecurity.org/military/library/policy/army/fm/100-7/f1007 13.htm, visitado no dia 4 de janeiro de 2010 - All military operations are driven by political considerations. However, MOOTW are more sensitive to such considerations due to the overriding goal to prevent, preempt, or limit potential hostilities. In MOOTW, political considerations permeate all levels and the military may not be the primary player. As in war, the goal of MOOTW is to achieve national objectives as quickly as possible and conclude military operations on terms favorable to the United States and its allies. 
Existem outros indicadores que mostram o movimento que a sociedade científica esta tomando em direção ao reatamento da geografia e das ciências militares: o restabelecimento do Grupo Especial de Geografia Militar na Associação de Geógrafos Americanos, notável que na direção deste grupo estão membros da sociedade civil, professores universitários. Segundo Gilewitch (2003), no ano de 2003, a Conferencia de Geologia e Geografia Militar foi responsável por aumentar os trabalhos, discussões e debates na área, servindo as necessidades dos Estados Unidos e encorajando trabalhos futuros.

\section{Guerra do Vietnã: quando a tecnologia subestimou a geografia militar.}

Muitos trabalhos já foram feitos sobre a Guerra do Vietnã, os dados são bem minuciosos sobre este conflito, não iremos analisar os pormenores do conflito, mas nós iremos analisar a logística, estratégia e inteligência de alguns pontos deste conflito para exemplificar não só o estudo da geografia militar deste conflito, mas o que os estadunidenses levaram de lição deste grande conflito e quais as principais mudanças na maneira de se fazer guerra neste período e como se faz atualmente, ou quais os erros da estratégia no Vietnã, que as forças armadas dos Estados Unidos superaram, e quais os erros que podem se repetir nas suas novas guerras.

Alguns números chamam atenção para o horror que foi a guerra do Vietnã que começa em 1961 com um decreto do Presidente Kennedy que enviou assessores militares ao Vietnã do Sul, pois a infiltração comunista ao sul poderia atrapalhar o plano global de contenção ao comunismo. Em 1963 os Estados Unidos já tinham enviado 12.000 homens e helicópteros armados. A guerra começou realmente quando navios de patrulha americanos foram atacados no golfo de Tonquim em julho de 1964. Até o fim do conflito (1974), as Forças Armadas dos Estados Unidos enviaram cerca de 2 milhões e 300 mil homens dos quais morreram mais de $46 \mathrm{mil}$ e 300 mil feridos. Enquanto $o$ Vietnã do Sul empreendeu mais de 1 milhão de homens com mais de 180 mil mortos. O Vietnã do Norte empreendeu 2 milhões de homens dos quais $900 \mathrm{mil}$ foram mortos na guerra. $O$ custo total desta guerra girou em torno de 720 
bilhões de dólares ${ }^{17}$. O conflito terminou com Vietnã unificado reatado com a União Soviética, rompido com a China e reaproximação com a França.

A questão mais importante, sobre a geografia militar, que se pode fazer sobre este conflito, o mais extenuante da Guerra Fria, é: como os Estados Unidos perderam a guerra se morreram mais dos seus inimigos do que dos seus amigos?

Eis a guerra de guerrilha! Temos duas teses em confronto sobre a guerra na Guerra do Vietnã que podem ser traduzidas pelos seus nomes operacionais: a "Linha McManara", plano americano de combate para bloquear o acesso dos Vietcongs ao Vietnã do Sul e a trilha Ho Chi Minh, plano do Vietnã do Norte de abastecer a guerrilha empreendida no Vietnã do Sul, através do Laos e Camboja como mostra a figura a seguir.

\section{“A Trilha Ho Chi Minh"}

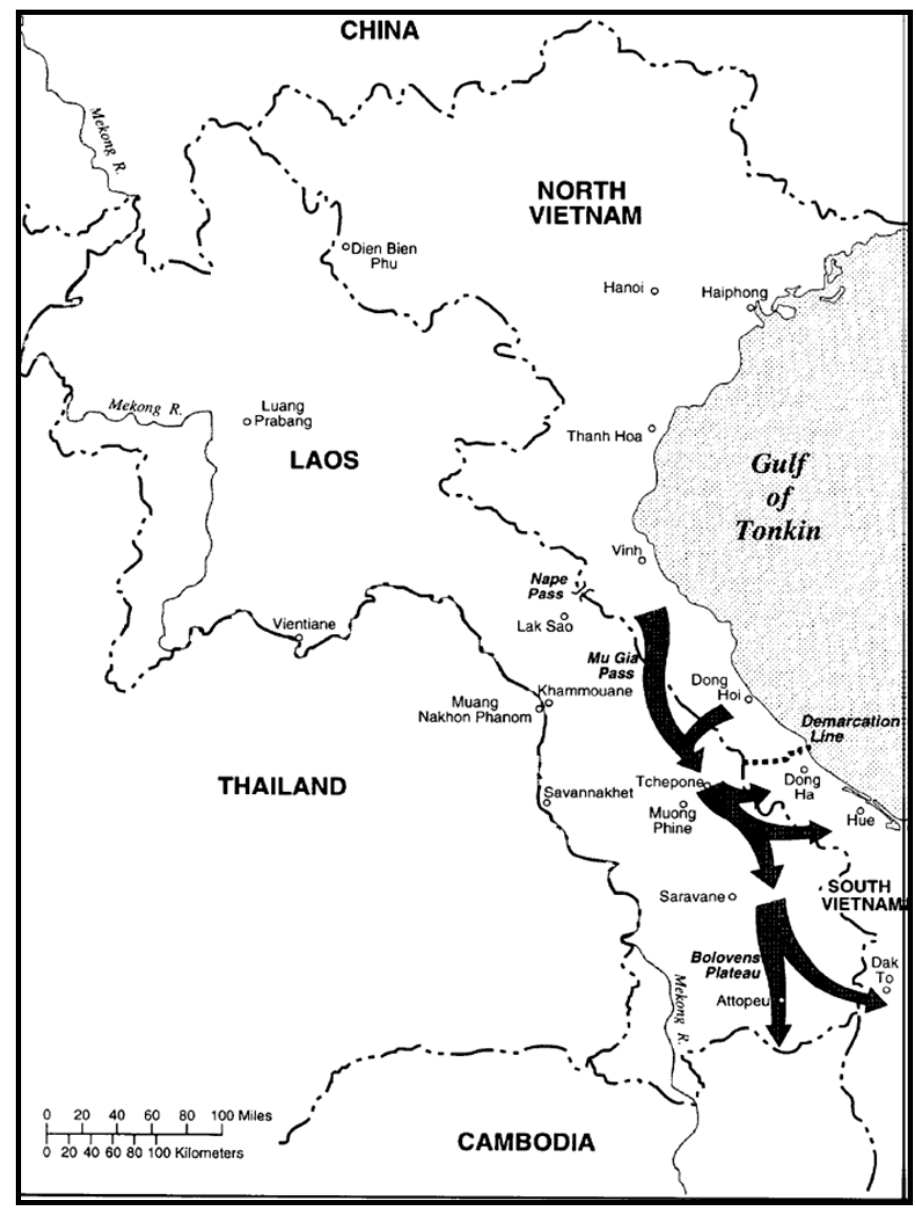

Figura 8 - Fonte: COLLINS, 1998: 369

\footnotetext{
${ }^{17}$ In: www.militarypower.com.br/fram4-warVietn.htm - acesso dia 5 de janeiro de 2010.
} 
A Trilha Ho Chi Minh, como já foi explicada, ligava o Norte do Vietnã - o Delta do Rio Vermelho - com o sul do Vietnã pelo Laos e Camboja e foi indispensável para o abastecimento das forças comunistas ao sul do paralelo 17․ A Força Aérea Americana bombardeou intensamente a região, entre 1965 e 1971 foram jogados mais peso em bomba do que toda a Segunda Guerra Mundial, os resultados não foram tão promissores quanto se pensava. Em 1967 os Estados Unidos já haviam mandado mais de 500 mil homens para combater, construíram a "Linha McNamara" para impedir a penetração dos Vietcongs, é verdade que até 1968 podemos dizer que os planos estadunidenses obtinham êxito e os Vietcong tiveram seus maiores reveses.

Porém no início de 1967 os vietcongues haviam sido derrotados na área de Saigon, nas operações Cedar Falls e Junction City, e fracassaram nos ataques às bases da Linha McNamara em Khe Sanh, Gio Linh e Con Thien. De 1965 a 1968, os EUA empreenderam uma série regular de bombardeamento aéreo do Vietnã do Norte, de cunho estratégico, denominada Operação Rolling Thunder, tendo sido realizados 300.000 vôos e lançadas cerca de 860.000 toneladas de bombas. Os danos causados foram grandes: $77 \%$ dos depósitos de munição, 65\% das instalações de combustível, 59\% das usinas elétricas e $55 \%$ das principais pontes. ${ }^{18}$

Dois nomes foram muito importantes na ofensiva vietcong: Ho Chi Minh e o General Giap. Eles conduziram a guerra em três fases: inicialmente ataques isolados tipo guerra de guerrilha; depois ataques mais vultuosos, como os ataques a "Linha McNamara" e as bases em Khe Sanh e Gio Com Thien onde muitos vietcongs morreram; e no fim quando o balanço das forças favorecessem, seria a hora das ações convencionais.

A Trilha Ho Chi Minh começou a ser construída durante os anos 50 nas guerras de independência do Vietnã, é como os vietnamitas chamam o período que vai da invasão japonesa na Segunda Guerra Mundial até o fim da Guerra do Vietnã em 1974, foram abertas estradas e perfurado túneis em toda a região do confronto que pudesse ligar o norte com o sul. Homens, mulheres, garotos e garotas dedicados a apoiar as forças com material necessário como armas, munição, comida, medicamento, informação.

\footnotetext{
${ }^{18}$ In: www.militarypower.com.br/fram4-warVietn.htm - acesso dia 5 de janeiro de 2010
} 
O Exército do Vietnã do Norte começa a ser um exército regular e bem treinado com uma excelente movimentação pelo terreno e bastante determinação e o seu armamento passa a ser exclusivamente soviético, ou seja a logística do abastecimento das munições é homogeneizado. Tudo isso foi ignorado pelo alto escalão dos oficiais das Forças Armadas dos Estados Unidos, os estadunidenses acreditavam mais no fracasso das forças francesas do que na organização tática e estratégica do Vietnã do Norte.

Entre 1949 e 50, as forças de guerrilha foram transformadas em destacamentos e batalhões. Posteriormente, com o recebimento de material bélico através da fronteira chinesa, Giap transformou seus batalhões em regimentos, logo chegando a mobilizar seis divisões, cada uma delas com cerca de 10.000 homens. ${ }^{19}$

Depois do cerco a Dien Bien Fhu e com a rendição da França que já recebia apoio dos Estados Unidos. Vietnamitas e franceses sentaram-se na mesa de reuniões em Genebra em 1954 e o resultado das reuniões foi a formação de dois novos Estados: o Vietnã do Norte e o Vietnã do Sul divididos no paralelo $17^{\circ}$. Mas a organização do Vietnã do Norte foi impressionante montando uma maquina estatal capaz de influenciar a região e expandir o comunismo na região.

Quando, o Estados Unidos começou a intervir no governo do Vietnã do Sul para fortalecer o capitalismo na região, não supunham os estadunidenses que o conhecimento do teatro da guerra adquirido contra os franceses e a forte organização do Vietnã do Norte, que de 1954 à 1961 montou uma maquina estatal capaz de mobilizar mais de 2 milhões de pessoas no esforço de guerra em dez anos, e com conhecimento do território que é bastante irregular, com paisagens naturais diversificadas como planaltos, florestas tropicais, pântanos, rios, campos, estradas, túneis e a difícil movimentação na época das monções, não podendo esquecer da disciplina do soldado vietnamita que ao combater a grande força americana com suas máquinas de destruição de massas, foram heróis e doaram com suas vidas

\footnotetext{
${ }^{19} \ln$ : www.esao.ensino.eb.br/paginas/.../insuficiencia e abundancia- acesso dia 5 de janeiro
} 
(cerca de 900 mil vidas) a formação de sua nação integrando e rompendo as fronteiras firmadas no acordo de Genebra.

Depois dos Estados Unidos bombardearem de maneira intensa o Vietnã do Norte, Laos, Camboja e Vietnã do Sul, na tentativa de bloquear a trilha Ho Chi Minh, o governo percebeu que o fluxo não cessava, portanto depois de instaladas no território "inimigo" entre 1966 e 1967, as forças armadas americanas empreendem uma nova operação militar, Plano El Paso, com a liderança do Presidente Lyndon B. Johnson e o General William C. Westmoreland. O Plano envolvia os bombardeios direcionados, a procura dos pontos de armazenamentos, bloqueio das trilhas e túneis dos vietnamitas do norte e vietcongs ao longo do rio Mekong e o bloqueio das estradas por onde passavam os veículos motorizados que levavam armas e suprimentos para os revolucionários infiltrados no Vietnã do Sul.

O período que ocorreu esta operação foi entre novembro de 1967 a março de 1968, e sua intenção era interromper de uma vez por todas o apoio que as forças do norte davam aos comunistas do sul, procurando e destruindo (search and destroy). Foram 18 meses consecutivos que atravessaram o período seco e o período chuvoso. No período chuvoso é necessário reduzir a velocidade do tráfego veicular de apoio, e as tropas, e divisões ficam isoladas uma da outra em caso de enchentes. As cheias são impressionantes aumentando muito o nível dos rios que muitas vezes transbordam com a influência dos ventos úmidos que vem do nordeste e sudoeste do Golfo de Tonkin como podemos observar na figura 9 e 10.

Monção de Nordeste

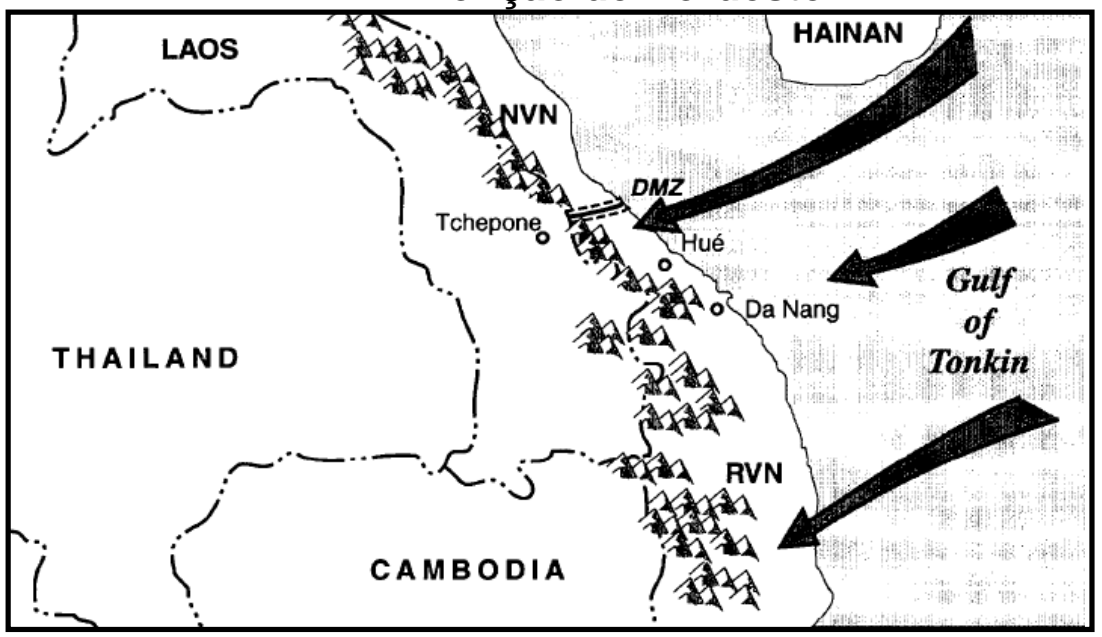

Figura 9- Fonte: Collins, 1998: 376. 


\section{Monções de Sudoeste}

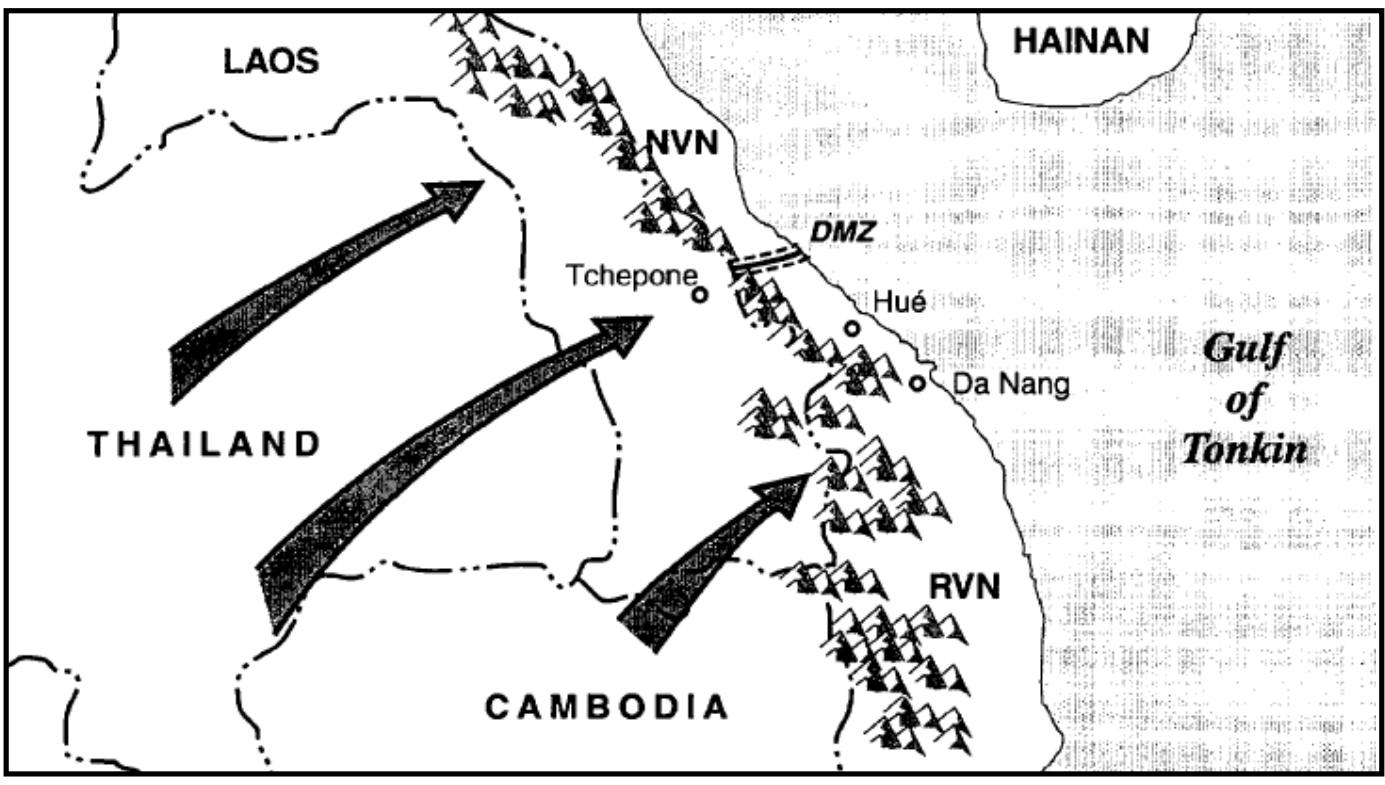

Figura 9 - Fonte: Collins, 1998:376.

Em 8 de abril de 1966, o primeiro ministro do Vietnã do Norte, Pham Van-Dong, ao perceber que as Forças Armadas norte-americanas não iriam simplesmente aceitar a influência de um governo de diretrizes comunistas na região declarou os "Quatro Pontos" de sua política de guerra, segundo Pomeroy(1967) :

-Reafirmação dos direitos fundamentais do povo vietnamita : paz, independência, soberania, unidade, integridade territorial, retirada das tropas norteamericanas, e fim da intervenção norte-americana no Vietnã conforme os acordos de Genebra.

- estrito respeito aos acordos de Genebra até a reunificação do país, em particular no terreno militar.

- os assuntos do Vietnã do Sul devem ser controlados pela Força de Libertação Nacional.

- a unificação dos dois estados do Vietnã devem ser assunto do povo desta região sem ingerências externas. $^{20}$

20 In: POMEROY (1967) Guerrillas y contraguerrillas- Los "cuatro puntos" de Pham VanDong: - reafirmación de los derechos fundamentales del pueblo vietnamita: paz, independencia, soberanía, unidad, integridad territorial, retirada de las tropas norteamericanas e fin de la intervención em Vietnam conforme a los acuerdos de Ginebra; - extricto respeto de los acuerdos de Ginebra hasta la reunificación del país, en particular em el terreno militar;- los assuntos de Vietnam del Sur deben ser arreglados conforme al programa del F.N.L; - la reunificación de los dos Vietnam será asunto del pueblo de ambas zonas, sin ingerências extranjeras. 
Durante o tempo de monções a trilha Ho Chi Minh não era ativada pelos vietnamitas do norte e vietcongs, o fluxo diminuía. Quando as forças armadas americanas estavam dentro do terreno da antiga Indochina e isoladas no fim das monções começa a Grande Ofensiva Tet (Ano novo lunar), combinando o cerco Khe Sanh com ataques a cidades do Vietnã do Sul, cerca de 200 mil soldados participam da ofensiva.

Por volta de $11 \%$ das perdas americanas ocorreram nas operações de busca e destruição ou operação de aldeias nas áreas florestadas do Mekong estes foram alvos fáceis pois estavam isolados de suas bases e as tropas de apoio tinham dificuldade de se aproximar de uma área de ataque.

\begin{abstract}
A ofensiva do Tet iniciou-se na noite de 30 de janeiro de 1968, após intenso bombardeio com morteiros e foguetes, quando as forças do Exército nortevietnamita (ENV) e do Vietcongue, atacaram simultaneamente cinco grandes cidades, 36 capitais de província, 64 capitais de distrito e cinqüenta aldeias. Os dois principais alvos foram a capital Saigon e a cidade imperial de Huê. ${ }^{21}$
\end{abstract}

Depois da Ofensiva do Tet, os planos americanos foram fracassados. No período de 1968-74 foram poucos os combates e este momento foi marcado por uma série de retiradas, desânimo das tropas e o problema de logística no abastecimento das bases isoladas no interior do território da antiga Indochina, a opinião pública estadunidense se colocando contra a guerra, decretaram a vitória tática do Vietnã do Norte. Mas neste período foi observado um problema muito grande na logística do exército do Vietnã do Norte e Vietcongs que muitas vezes erravam os locais para depositar o suporte de uma determinada área e combate, fazendo prolongar ainda mais os esforços da expulsão dos estadunidenses do território e aumentar ainda mais o número de óbitos no conflito.

Os pontos fundamentais para o fracasso das operações das Forças Armadas norte-americanas foram: os ventos das Monções que encorajaram e desencorajaram muitas operações militares; as circunstancias geográficas afetaram $\mathrm{o}$ abastecimento, transporte, medicamentos e outros

\footnotetext{
${ }^{21}$ In: www.militarypower.com.br/fram4-warVietn.htm - acesso dia 5 de janeiro de 2010
} 
requisitos logísticos influenciando muito nas operações de combate; estes problemas foram muito intensificados pelas longas distâncias entre uma base e outra (como podemos observar no mapa das bases norte-americanas na região- Figura 11) tanto as bases de suporte quanto as bases de combate se encontravam muito distantes uma das outras; os materiais de construção para as fortificações eram escassos; a rede rodoviária precária aumentou a dependência militar das aeronaves (principalmente os helicópteros) e da rede hidrográfica para realização do transporte; montanhas florestadas reduzem a mobilidade e precisão das aeronaves se comparado ao terreno aberto; os paraquedistas e os helicópteros são bons para apoiar pequenas unidades isoladas na floresta, mas grandes formações precisam de rodovias ligando a área ao suporte.

"Bases americanas e a rede rodoviária"

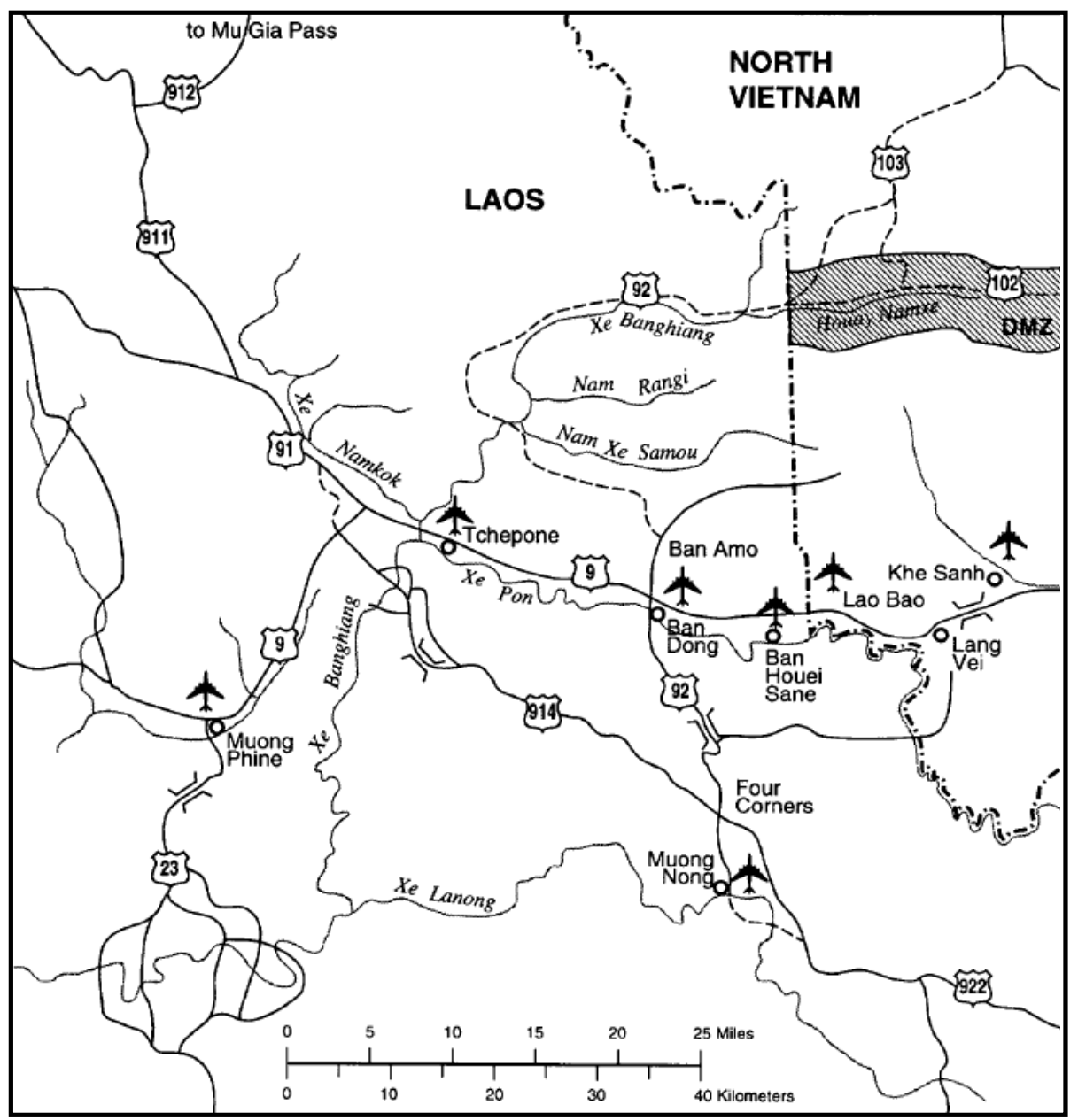

Figura 11- Fonte Collins, 1998: 370 
A geografia mais uma vez foi uma disciplina fundamental para que as diretrizes do confronto fossem dimensionadas de uma maneira mais precisa. A desconfiança do fracasso francês na década de 1950, a falta de informação sobre a estrutura montada pelo Presidente Ho Chi Minh e pelo seu General Giap foram simplesmente descartadas sendo consideradas como apenas uma propaganda comunista, o desconhecimento da geografia do teatro de guerra (população, relevo, hidrografia, vegetação, clima, redes de transporte e telecomunicações) e a falta de conhecimento da determinação e disciplina do povo do Vietnã foram os motivos da derrota americana.

A confiança dos Estados Unidos estava sobre uma nova concepção de combate: A guerra dos helicópteros! As forças armadas estadunidenses colocavam em prática uma nova tecnologia que poderia colocar a geografia militar em xeque. Os helicópteros eram uma maneira de cobrir um espaço muito grande de maneira mais precisa do que a dos aviões. Os Franceses em sua guerra pela Indochina não tiveram tais recursos e 0 cerco de Dien Bien Fhu, pelos exércitos do Gen. Giap, foi muito bem sucedido, já as forças norteamericanas tinham muito mais recursos tecnológicos e financeiros para suprir o cerco a Khe Sanh.

A analogia com Dien Bien Phu era inevitável. Para o público norte-americano, Khe Sanh assemelhava-se terrivelmente à batalha final dos franceses: os fuzileiros estavam cercados por uma força muito superior com forte apoio de artilharia e totalmente dependentes do apoio aéreo. As semelhanças terminavam por aí, no entanto, os franceses tinham sido colocados em uma armadilha em um vale inacessível, com poucas peças de artilharia, enquanto os americanos tinham uma formidável quantidade de obuseiros e morteiros, além de artilharia de longo alcance, que poderia bater os inimigos a longa distância do seu perímetro. Em contraste com os franceses, que sentiram grande falta do apoio aéreo, os fuzileiros norte-americanos contavam com o apoio de uma formidável frota de helicópteros e aeronaves de carga, que jamais foi impedida de pousar no posto. Acima de tudo, os fuzileiros podiam contar com o apoio dos bombardeiros B-52, que iriam despejar sobre os sitiantes mais de 95.000 toneladas de bombas, o maior poder de fogo convencional até então despejado em uma guerra sobre um alvo tático. Estes bombardeios 
foram responsável por quase $90 \%$ das 10.000 mortes entre os vietnamitas. ${ }^{22}$

Entretanto, as Forças Armadas norteamericanas não conseguiram bloquear as rotas de abastecimentos dos Vietnamitas do norte e dos Vietcongs. Embora, no cerco a Khe Sanh, os estadunidenses tenham conseguido evitar a derrota com um número bem inferior de combatentes, não evitaram a derrota na guerra. O número de helicópteros usados para abastecer a base foi muito grande, muitos helicópteros foram abatidos, o custo foi exacerbado.

As técnicas de suprimento pelo ar tinham evoluído bastante desde o tempo dos franceses. Quando, seis semanas após o início do cerco, uma aeronave C-130 foi destruída na pista de pouso por um tiro de morteiro, o suprimento passou a ser entregue com a utilização de técnicas como a extração de cargas, lançamento a baixa altitude e por helicópteros pesados. O poderio logístico norte-americano, aliado ao espírito de luta dos fuzileiros, permitiram-lhes resistir, sofrendo 205 mortos e 852 feridos, obrigando os comunistas a levantarem o cerco. Nesta ocasião, a ligação por terra com o grosso das forças americanas já tinha sido restabelecida. Mais tarde, constatando a inutilidade de manter o posto, o Comando norte-americano determinou sua evacuação.

Doravante, podemos analisar pelo olhar da geografia quem ganhou a guerra. Do ponto de vista da geopolítica a resposta é bem clara; evacuação das forças norteamericanas, avanço das tropas comunistas ao sul, e posterior unificação do Vietnã. Isto é a geopolítica, quando mexemos com as fronteiras e quando a ideologia é posta em prática. A unificação do norte com o sul em um regime comunista demonstra claramente uma derrota do novo imperialismo. A geopolítica salta aos olhos da opinião pública que sempre observou este termo apenas como uma justificativa do Estado-maior estadunidense de empreender uma guerra, entretanto foi justamente este conceito que foi usado para condenar as ações americanas na região da Indochina. Para mídia os conceitos podem ser descartados ou não

\footnotetext{
${ }^{22}$ In: www.esao.ensino.eb.br/paginas/.../insuficiencia e abundancia- acesso dia 5 de janeiro

${ }^{23}$ In: www.esao.ensino.eb.br/paginas/.../insuficiencia e abundancia- acesso dia 5 de janeiro
} 
dependendo de sua conveniência e era conveniente, não só para mídia, mas para opinião pública deixar que o aspecto geopolítico do conflito sobressaísse aos demais aspectos da geografia. De certa forma, é importante esclarecer que qualquer ato de guerra é injustificado e que a guerra é resultado da ignorância humana, mas as meias verdades colocadas pela mídia podem ser analisadas como mentiras inteiras, sempre vinculando o seu interesse político e econômico por trás das informações expostas para opinião pública.

No entanto, Yves Lacoste (1976) lança um artigo na revista Hérodote nำ - "Enquête sobre o bombardeamento de diques do rio Vermelho (Vietnã, verão 1972)" - demonstrando "o plano de destruição sistemática dos diques que protegem as planícies densamente povoadas do Vietnã do Norte" (LACOSTE, 2008:27). Ora esta análise esta muito mais voltada à disciplina da geografia militar, que advém das análises da geografia regional, do que das análises geopolíticas que são muito mais ideológicas. Como conseqüência os estadunidenses conseguiram alterar o meio geográfico, ao alagar as planícies e terraços densamente ocupados, e realizar uma migração forçada da população que antes da guerra era predominantemente rural: "trata-se de modificar radicalmente a repartição espacial do povoamento praticando, por meios vários, uma política de reagrupamento nos "hameaux estratégicos" e a urbanização forçada" (Ibidem, 2008).

A conclusão de Yves Lacoste sobre a Guerra do Vietnã em "A geografia - isso serve em primeiro lugar para se fazer a guerra", deixa claro como seriam as novas intervenções do novo imperialismo. Durante a década de 80 , os Estados Unidos praticamente não realiza nenhuma grande intervenção regional, mas na década de 1990 e na primeira década do século $\mathrm{XXI}$, as tentativas de transformação do meio geográfico para fins determinados serão colocadas em prática mais uma vez, com maior ou menor intensidade, concertando alguns erros do passado, e às vezes persistindo em antigos erros.

A guerra da Indochina marca, na história da guerra e da geografia, uma nova etapa: pela primeira vez, métodos de destruição e de modificação do meio geográfico conjuntamente nos seus aspectos "físicos" e "humanos" foram executados para suprimir as condições geográficas indispensáveis à vida de várias dezenas de milhões de homens. (LACOSTE. 2008:27) 
Não existem, efetivamente, vencedores ou perdedores em uma guerra. Mas cabe a geografia analisar segundo os objetivos de cada uma das partes quem alcançou seus objetivos nos conflitos e quais foram às mudanças na organização territorial e com isso analisar como se realiza a apropriação dos novos espaços em relação suas respectivas sociedades. Podemos aceitar a derrota dos Estados Unidos se seu objetivo fosse o de fortalecer o Vietnã do Sul e reverter a influência do avanço do comunismo na região. Mas se analisarmos as mudanças na organização do território do Vietnã que possuía uma população predominantemente rural e mesmo sendo oficialmente comunista, atualmente, é considerado um novo tigre asiático e um dos países que mais cresce economicamente na sua região se transformando numa economia de base industrial exportadora, seguindo o exemplo de países como a Tailândia, Indonésia e outros; desta forma, poderíamos afirmar que os resultados em longo prazo favoreceram o novo imperialismo.

\section{A Nova Geografia Militar: Intervenção em Kosovo, Guerra do Iraque e Guerra do Afeganistão.}

Com o fim da União das Repúblicas Socialistas Soviéticas entramos na década de 1990, num contexto de transformação da ordem política mundial, no que alguns teóricos chamam de período pós Guerra Fria, embora esse termo levante algumas controvérsias; entretanto não é o propósito do presente trabalho discutir estes conceitos específicos e sim analisar quais foram as mudanças na forma de realizar as guerras segundo as concepções da nova geografia militar.

De acordo com Fink (2003) em sua tese apresentada na Faculty of The Flecther Scholl of Law and Diplomacy intitulada; Origins of intervetion: western tradition of thinking about international politics and NATO's intervention in 1999 Kosovo crisis, os anos de 1990, marcaram um novo modo de conduzir os conflitos internacionais que ficaram conhecidos como as intervenções militares para fins humanitários como, por exemplo, a Guerra do Golfo, no início dos anos de 1990, que tinha por meta libertar o povo do Kwait do julgo da tirania do governo do Iraque que infligiu às condutas internacionais ao romper 
com os acordos diplomáticos partindo para uma invasão no país vizinho. Outro exemplo de intervenção foi em relação à crise em Kosovo, no fim da década de 1990, quando a OTAN (Organização e Tratado do Atlântico Norte) resolve que o uso da força seria necessário para fins humanitários e assim libertar os Albaneses de Kosovo do julgo do tirano Milosevic.

Fink (2003) afirma que o conflito em Kosovo é o caso mais importante na história recente das intervenções militares com fins humanitários, correspondendo na maior aliança e uso de forças na história da OTAN, incluindo a contínua importância das relações trans-Atlânticas na região. Aliança abarcou as forças armadas da Alemanha, França, Reino Unido sob a liderança dos Estados Unidos. Este estudo de caso oferece um novo modelo conceitual para compreensão nas decisões de intervenções humanitárias. De acordo com Fink (2003), este novo modelo envolve de maneira lógica três maneiras do pensamento sobre a política internacional identificados pela escola britânica ${ }^{24}$ : o realismo, o racionalismo e o revolucionismo - três aspectos desta intervenção.

Aplicando este modelo no caso da Intervenção de Kosovo é possível observar nesta ação os seguintes conceitos: anarquia internacional(realismo), cooperação e associação (racionalismo), e solidariedade moral (revolucionismo). As decisões foram pautadas sobre esta ótica, o que, de certa forma, justificou a obrigação do uso da força militar. É irônico o uso da violência em razão de uma causa humanitária e dos direitos humanos e a complexidade por causa da tensão em meio às instituições de direito internacional, poderes políticos, e a esperança do bem moral de diversos líderes completam a questão. É uma clássica operação militar diferente da guerra (MOOTW) típica das intervenções dos anos de 1990.

O contexto deste episódio deve remontar o período entre outubro de 1998 e maio de 1999, quando as nações da OTAN estavam divididas sobre uma possível intervenção militar em Kosovo. Diferente das situações políticas domésticas e divergentes interesses nas políticas externas, os aliados

\footnotetext{
${ }^{24}$ Martin Wight apontou as incongruências de duas escolas de pensamento nas análises das relações internacionais à oposição entre o realismo e o idealismo e propôs uma nova metodologia em que olhasse estas questões de maneira mais crítica usando conceitos mais relativos e não absolutos, isto ficou conhecido como a Escola Britânica de Política Internacional.
} 
discutiam como parar a limpeza étnica dos Albaneses em Kosovo realizada Milosevic. Os interesses eram muito variados. O Reino Unido mesclava 0 humanitarismo com interesses estratégicos. Os franceses preferiam negociar em separado, esperando uma resolução do Conselho de Segurança das Nações Unidas fortificando seus interesses nacionais com a promoção dos direitos humanos. Os Estados Unidos utilizou os dois argumentos: a resolução do Conselho de Segurança junto com o fortalecimento da OTAN nas relações internacionais e o discurso humanitário. Já a Alemanha sofria um embate entre o discurso humanitário e o antimilitarismo e entre a obrigação legal da nãointerferência e sua posição frente a OTAN.

Como não houve consenso no Conselho de Segurança das Nações Unidas, pois Estados Unidos e Reino Unido achavam que o argumento da intervenção militar era o suficiente para acabar com a crise, França e Alemanha diziam que uma ação sem parâmetros deveria ser considerada ilegítima pelo Conselho de Segurança. No final do embate, a intervenção militar apareceria como a única resposta e os fatores regionais eram por si só a sua justificativa e autorização.

A Intervenção em Kosovo durou 78 dias e foram utilizados portaaviões, bombardeios, e tropas regulares. Os resultados foram bastante alarmantes, pois mísseis e bombas atingiram escolas, consulados e outros alvos que não tinham relação direta com esta questão. O número de tropas nestes conflitos fora diminuto em relação às guerras convencionais. As novas tecnologias permitem, com uma precisão quase cirúrgica, realizar uma destruição de alvos estratégico-militares, abrindo o caminho para infantaria e cavalaria motorizada que tiveram, apenas, o trabalho de capturar Milosovic, com poucos enfrentamentos. Esta tese da guerra rápida e com pouco uso regimentos mais reduzidos foi a tônica dos conflitos nos anos de 1990. Parece que mais uma vez a geografia regional estaria fadada ao desaparecimento e a geopolítica se sobreporia a estes fatores.

Os resultados posteriores na região foram a fragmentação de uma lugoslávia formada por Sérvia, Montenegro, Macedônia e Albânia, embora Kosovo ainda não seja reconhecida como um estado independente por todos os estados da região. 
Todo este prospecto de um novo modo de se fazer a guerra se transformaria na entrada do século XXI, com os ataques terroristas que derrubariam as torres gemias em Nova York. Com isso os "estrategistas norte americanos divulgaram a chamada 'Doutrina Bush', a qual pretende justificar o direito de intervenção dos Estados Unidos em qualquer país do mundo sem consulta à ONU" (MARTIN, 2004:33). Isto porque mais uma vez França e Alemanha se colocaram contra e desta vez vetaram o uso da força em uma aliança conjunta apoiada pelo Conselho de Segurança da ONU. A coalizão liderada por Estados Unidos e Reino Unido estabeleceu o que ficou conhecido como "ataque preventivo" a estados que supostamente apoiavam grupos terroristas como os da Al-Qaeda, no caso do Afeganistão e no armazenamento de armas de destruição em massa, no caso do Iraque.

Vale lembrar que a ofensiva contra os terroristas que começa no final de 2001 com bombardeios ao Afeganistão e dura até os dias atuais, com a ocupação do Iraque (desde 2003), não conseguiu desmantelar o grupo terrorista Al-Qaeda e, também, não encontrou armas de destruição em massa. Mas um ponto nós podemos ressaltar, as operações militares diferentes da guerra da década de 1990(MOOTW), que pretendiam serem guerras rápidas e cirúrgicas para conter problemas regionais e humanitários, não foram enfatizados na forma de se fazer guerra na primeira década do século XXI.

Ao anilisar a Guerra no Iraque estes são os três argumentos básicos da invasão do Iraque e suas repercussões posteriores, segundo Demant (2004):

neutralizar o regime de Saddam Husseim que supostamente - tinha armas de destruição em massa; estabelecer, mediante a "mudança de regime", uma cabeça-de-ponte pró-ocidental no coração do Oriente Médio cada vez mais hostil aos interesses americanos e através disso, também "disciplinar" algumas potências européias que mostravam veleidades independentistas frente à supremacia norte-americana; em terceiro lugar, o motivo humanista de estabelecer uma democracia.

sabemos que o governo de Hussein era bem menos perigoso internacionalmente, do que se supunha. Suas armas de destruição em massa sumiram ou nunca existiram, provocando uma grave crise de confiança nas lideranças que as usaram - de boa fé ou má fé - para 
justificar a invasão. Motivo descartado portanto. Quando ao segundo argumento, geopolítico, o alcance do poder dos EUA aumentou de fato, mas à custa de minar sua legitimidade futura. A avaliação do motivo humanista, por outro lado, está ainda em aberto. Ele implica um projeto de engenharia social quase planetária, passível de criticas do ponto de vista moral e de viabilidade.

Portanto, dos três argumentos básicos da coalizão americana podemos apenas considerar como motivo mais evidente, o geopolítico estabelecer uma cabeça-de-ponte no coração do Oriente Médio. Agora podemos refletir na geografia regional militar e realizar 0 primeiro questionamento: porque o governo Bush preferiu o Iraque ao invés do Afeganistão? A geografia oferece bons argumentos para responder: primeiro o Golfo Pérsico é o canal central de entrada pelo mar no Oriente Médio; segundo as planícies da Mesopotâmia favorecem o uso da cavalaria pesada; terceiro, a infraestrutura do Iraque se concentra ao redor de Bagdá, incluindo a maior parte da população; quarto, o exército de Saddam Hussein não representava mais um obstáculo, sobretudo depois da guerra do golfo e dos posteriores embargos impostos pelos Estados Unidos, e por não ter um apoio interno de sua população dividida entre grupos étnico-religiosos distintos e que sofreram de maneira bastante dolorosa com a violência do governante.

Segundo, Keegan (2005), o exército de mais de 400 mil homens do Iraque - uma força duas vezes mais forte que a da coalizão - não enfrentou e não criou uma resistência como se previa.

O Iraque mobilizou um exército de quase 400 mil soldados, equipado com milhares de carros-decombate, veículos blindados e peças de artilharia. Ante o avanço de uma força invasora com apenas metade desse poder, o Exército iraquiano se encolheu. Não lutou na fronteira, não lutou nos obstáculos geográficos mais evidentes, praticamente não lutou nas cidades, não montou um último reduto de resistência na capital, onde boa parte da impressa internacional previa que Saddam faria sua Stalingrado.

O mapa de ação da coalizão no Iraque é a prova de que a ação de invasão foi rápida e correspondeu a pouca resistência. 


\section{"O Avanço sobre Bagdá"}

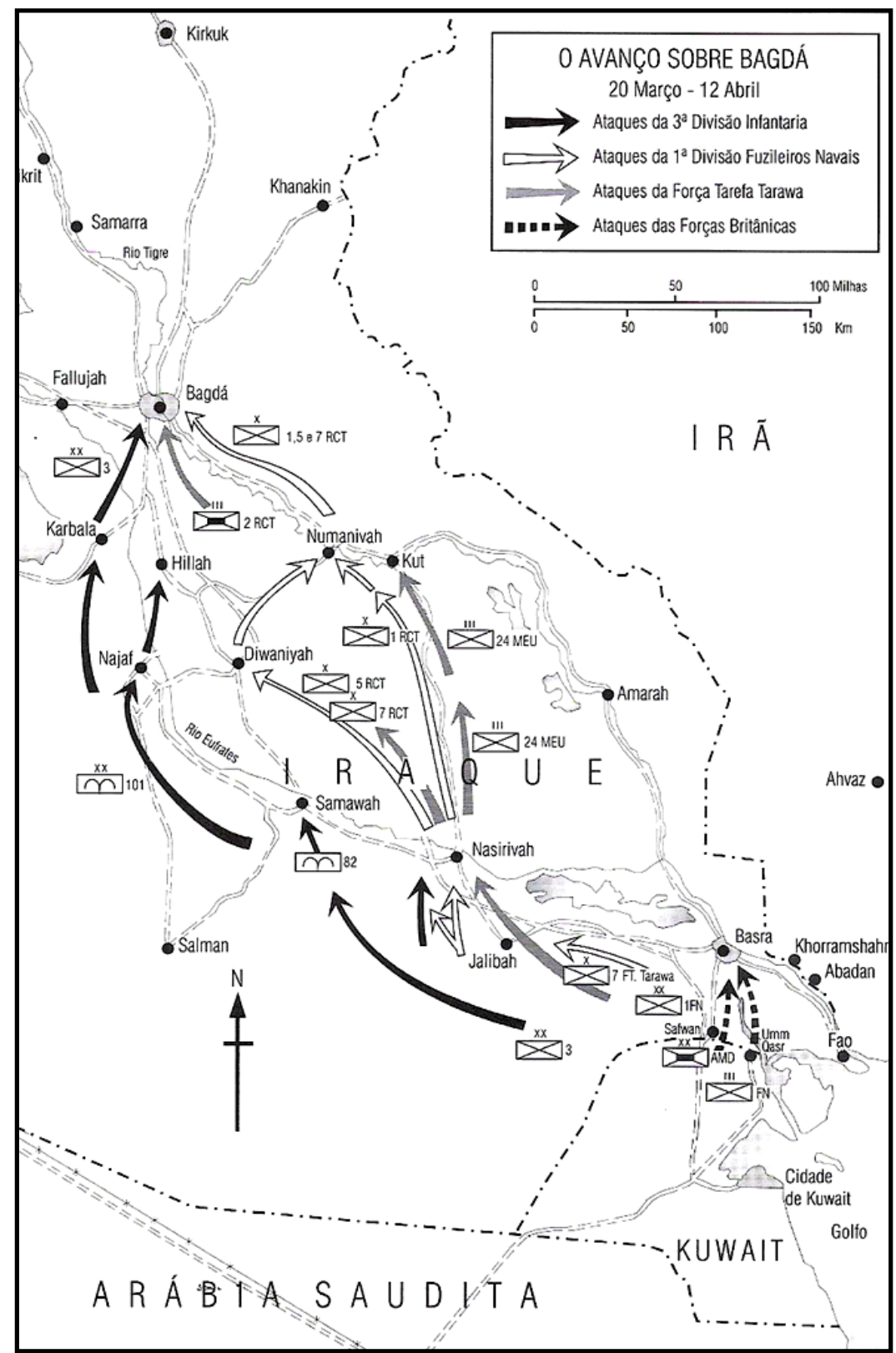

Figura 12- KEEGAN, 2005: 181

Entretanto, alguns números provam que esta não é apenas uma operação militar diferente de Guerra, e sim uma operação militar convencional de ocupação e controle político. Os Estados Unidos já somaram cerca de 160 mil soldados no Iraque dos quais 4 mil foram mortos. Quando comparado a Guerra do Vietnã percebe-se que a forma como o Iraque foi ocupado diminuiu muito o número de baixa do lado das forças armadas norte-americanas. Os gastos são surpreendentes em quase sete anos de guerra os estadunidenses já desembolsaram mais 500 bilhões de dólares sem contar os juros pagos aos 
empréstimos bancários, quando somados, ultrapassam os 800 bilhões de dólares. Mais do que os 600 bilhões gastos em doze anos de guerra do Vietnã.

A Guerra do Iraque já consumiu mais de US $\$ 504$ bilhões [R $\$$ 859,82 bilhões] dos cofres públicos americanos. Segundo um estudo do prêmio Nobel de economia Joseph E. Stiglitz, são estimados gastos de US\$ 3 trilhões [R \$ 5,1 trilhões] com os conflitos, caso as tropas permaneçam no Iraque até 2010. Somente os juros dos empréstimos para manter a guerra representam um gasto de US\$ 816 bilhões [R $\$ 1,39$ trilhão], de acordo com pesquisadores. O total supera os US\$ 670 bilhões [1,14 trilhão] gastos em 12 anos da Guerra do Vietnã.

Os números do lado do Iraque são mais impressionantes as estimativas mostram que já foram mortos mais de 200 mil civis em ataques diretos, indiretamente estima-se mais de 1 milhão de pessoas mortas. A conclusão sobre essa pequena amostra de dados esclarece que a máquina de guerra americana é mais eficiente agora do que nunca e gera mais lucros para indústria da guerra do que outrora. A conseqüência para população iraquiana é a migração forçada aliada com a transformação do meio geográfico do seu país, algo muito parecido que ocorreu no Vietnã, e a instabilidade político-social em um país de maioria xiita, onde habitam duas minorias, os sunitas e os kurdos.

Um dos maiores indicativos da situação atual do país é a questão dos refugiados. Atualmente, um em cada cinco iraquianos é classificado como refugiado. Após cinco anos em queda, os pedidos de refúgio no mundo tiveram alta em 2007, principalmente devido ao aumento do número de solicitantes iraquianos, segundo o Alto Comissariado das Nações Unidas para Refugidos (Acnur).

O Acnur afirma que o conflito no Iraque fez com que 4,5 milhões de iraquianos deixassem suas casas. Destes, 2,4 milhões são deslocados internos. Outros 2 milhões estão refugiados principalmente nos países vizinhos, como Síria e Jordânia --não inclusos na lista de países mais industrializados. ${ }^{26}$

\footnotetext{
${ }^{25}$ In: Folha de São Paulo - 19/02/2008 - Entenda a Guerra do Iraque.

${ }^{26}$ In: Folha de São Paulo - 20/03/2008 - Sem consenso sobre número de vítimas, guerra do Iraque completa cinco anos.
} 
O governo Bush acreditou que o Iraque e não o Afeganistão deveria ser a concentração de esforços da política americana, mesmo porque a sua estratégia regional é pressionar o Irã - que com a guerra é cada vez mais presente na política do Iraque - os Estados Unidos estão num beco sem saída na região se saírem do Iraque deixaram um país instável de maioria xiita que se identifica muito mais com as políticas do Irã, também de maioria xiita, como afirmou o professor Peter Demant em entrevista a Folha de São Paulo;

Não acho que a maioria dos iraquianos esteja feliz com o aumento da influência iraniana. Historicamente, o Irã é o grande concorrente e inimigo do Iraque. Além disso, $\mathrm{O}$ Irã tem ambições de se tornar grande potência regional, e um projeto expansionista religioso islâmico. Isto agrada a uma parte dos iraquianos xiitas, mas não a todos, e é completamente rejeitado pela minoria sunita $e$, provavelmente também, pela grande maioria dos curdos. Os EUA ainda não deixaram o Iraque porque isso seria conceder uma "derrota militar e política". "Eles também deixariam o país indefeso contra a influência do Irã.

As eleições americanas, em 2008, giraram em torno de duas visões antagônicas da política dos Estados Unidos no Oriente Médio: os republicanos (Mcain) que afirmavam que os esforços deveriam ser o Iraque, pois a guerra estava sendo ganha no país; e os democratas (Obama) que afirmavam que os esforços deveriam estar no Afeganistão, visto que tudo começou pelo combate ao terror e o Iraque não representa mais tal ameaça. Os democratas vencem as eleições e o foco da guerra muda do Iraque para o Afeganistão.

OXFORD, Mississippi, 27 Set 2008 (AFP) - O candidato democrata Barack Obama afirmou nesta sexta-feira que o verdadeiro centro da guerra contra o terrorismo é o Afeganistão, enquanto o republicano John McCain destacava que os Estados Unidos estão "vencendo no Iraque".

Para aqueles que afirmavam que o presidente Obama representaria um Farol pela paz no planeta mudando a ótica de uma política que gerou guerra e terror no mundo (doutrina Bush), têm ficado um pouco 
desapontados com o que veio acontecendo no ano de 2009, com uma exceção, o inusitado prêmio Nobel da Paz. Outros afirmavam que Obama representaria uma volta à política das Operações Militares Diferentes da Guerra (MOOTW) e que os Estados Unidos diminuiriam os contingentes militares na região do Oriente Médio, mas isto não vem acontecendo.

Mais uma vez, os números da guerra no Afeganistão estão alarmando o mundo e os Estados Unidos aumentarão ainda mais os esforços de guerra no Oriente Médio. O Presidente que foi eleito para trazer a paz para o mundo enviará no ano de 2010 mais 30.000 soldados para o país. A violência só vem aumentando no Afeganistão e tudo indica que a guerra contra o terror não esta indo muito bem como indica algumas notas sobre o conflito.

A ONU (Organização das Nações Unidas) anunciou recentemente que o número de civis mortos no conflito no Afeganistão aumentou $24 \%$ nos primeiros seis meses deste ano em relação ao mesmo período de 2008. O dado confirma $o$ que os militares estrangeiros e 0 governo afegão afirmavam há meses: o país asiático vive o pior e mais violento momento da guerra desde a invasão das forças estrangeiras, em 2001. O presidente americano, Barack Obama, assumiu com a proposta de investir mais no conflito "esquecido" pelo antecessor e prometeu um reforço inédito de 17 mil soldados e 4.000 militares para treinamento. Pela primeira vez, o gasto no Afeganistão superou os gastos no Iraque --um orçamento que garantiu ainda o dobro de verba para projetos de governança civil e desenvolvimento, US\$200 milhões por mês ${ }^{27}$.

A questão mais central das eleições americanas pode ser analisada, com bastante clareza, pela geografia. O Iraque representa maiores facilidades no acesso e na guerra de conquista, enquanto o Afeganistão é um país que tem uma posição central frente a dois interesses americanos: o Irã e o Paquistão e a luta contra o terror. Portanto, o Afeganistão é uma escolha mais geopolítica, mais ideológica e o Iraque é uma escolha mais militar, a geografia deste país não representa um obstáculo, já no caso do Afeganistão as coisas são bem diferentes. O discurso eleitoral de Obama é bem claro neste sentido.

\footnotetext{
${ }^{27}$ In: Folha de São Paulo - 18/08/2009 - Depois de oito anos, guerra no Afeganistão vive época mais violenta.
} 
WASHINGTON (JUN/2008) - O presidente dos Estados Unidos, Barack Obama, afirmou hoje que seu país deve "desbaratar, derrotar e desmantelar" a rede terrorista AlQaeda e o Taleban no Afeganistão e no Paquistão. Obama anunciou novos planos para a região. A iniciativa inclui 0 aumento da presença de tropas norteamericanas no Afeganistão. Obama disse que, caso o governo afegão caia em poder do Taleban, ou a AlQaeda mantenha seu poder, "aquele país será uma base para terroristas que querem nos matar".

O movimento das forças no sentido do Afeganistão pode ser um grande problema para os Estados Unidos. O território montanhoso não favorece o uso de cavalaria pesada, o uso de bombardeios já se mostrou ineficiente, mesmo com as novas bombas que perfuram o relevo e explodem no interior das cavernas. Há diversos grupos étnicos no país que representam interesses distintos e que podem às vezes se aliar contra um inimigo externo comum e isso fortaleceria muito o Talibã, por exemplo. E, por fim, o retrospecto histórico de guerra de conquista na região é bem negativo; a começar por Alexandre, o grande, império britânico, União Soviética. Todos perderam no Afeganistão. Uma carta de Eça de Queiroz (1880) que foi publicada na internet por Eduardo Maia Costa, Magistrado do Ministério Público é bem elucidativa.

Os ingleses estão experimentando, no seu atribulado império da Índia, a verdade desse humorístico lugar comum do sec. XVIII: «A História é uma velhota que se repete sem cessar(SIC).

O Fado e a Providência, ou a Entidade qualquer que lá de cima dirigiu os episódios da campanha do Afeganistão em 1847, está fazendo simplesmente uma cópia servil, revelando assim uma imaginação exausta.

Em 1847 os ingleses, «por uma Razão de Estado, uma necessidade de fronteiras científicas, a segurança do império, uma barreira ao domínio russo da Ásia...» e outras coisas vagas que os políticos da Índia rosnam sombriamente, retorcendo os bigodes - invadem 0 Afeganistão, e aí vão aniquilando tribos seculares, desmantelando vilas, assolando searas e vinhas: apossam-se, por fim, da santa cidade de Cabul; sacodem do serralho um velho emir apavorado; colocam lá outro de raça mais submissa, que já trazem preparado nas bagagens, com escravas e tapetes; e, logo que os correspondentes dos jornais têm telegrafado a vitória, o exército, acampado à beira dos arroios e nos vergéis de 
Cabul, desaperta o correame, e fuma o cachimbo da paz... Assim é exactamente em 1880.

No nosso tempo, precisamente como em 1847, chefes enérgicos, Messias indígenas, vão percorrendo o território, e com os grandes nomes de «Pátria» e de «Religião», pregam a guerra santa: as tribos reunem-se, as famílias feudais correm com os seus troços de cavalaria, príncipes rivais juntam-se no ódio hereditário contra o estrangeiro, o «homem vermelho», e em pouco tempo é tudo um rebrilhar de fogos de acampamento nos altos das serranias, dominando os desfiladeiros que são o caminho, a estrada da Índia... E quando por ali aparecer, enfim, o grosso do exército inglês, à volta de Cabul, atravacado de artilharia, escoando-se espessamente, por entre as gargantas das serras, no leito seco das torrentes, com as suas longas caravanas de camelos, aquela massa bárbara rola-lhe em cima e aniquila-o.

Foi assim em 1847, é assim em 1880. Então os restos debandados do exército refugiam-se nalguma das cidades da fronteira, que ora é Ghasnat ora Kandahar: os afegãos correm, põem o cerco, cerco lento, cerco de vagares orientais: o general sitiado, que nessas guerras asiáticas pode sempre comunicar, telegrafa para o visorei da Índia, reclamando com furor «reforços, chá e açúcar»! (Isto é textual; foi o general Roberts que soltou há dias este grito de gulodice britânica; o inglês, sem chá, bate-se frouxamente). Então o governo da Índia, gastando milhões de libras, como quem gasta água, manda a toda a pressa fardos disformes de chá reparador, brancas colinas de açúcar, e dez ou quinze mil homens. De Inglaterra partem esses negros e monstruosos transportes de guerra, arcas de Noé a vapor, levando acampamentos, rebanhos de cavalos, parques de artilharia, toda uma invasão temerosa... Foi assim em 1847, assim é em 1880.

Esta hoste desembarca no Industão, junta-se a outras colunas de tropa índia, e é dirigida dia e noite sobre a fronteira em expressos a quarenta milhas por hora; daí começa uma marcha assoladora, com cinquenta mil camelos de bagagens, telégrafos, máquinas hidráulicas, e uma cavalgada eloquente de correspondentes de jornais. Uma manhã avista-se Kandahar ou Ghasnat; e num momento, é aniquilado, disperso no pó da planície o pobre exército afegão com as suas cimitarras de melodrama e as suas veneráveis colubrinas do modelo das que outrora fizeram fogo em Diu. Ghasnat está livre! Kandahar está livre! Hurrah! Faz-se imediatamente disto uma canção patriótica; e a façanha é por toda a Inglaterra popularizada numa estampa, em que se vê o general libertador e o general sitiado apertando-se a mão 
com veemência, no primeiro plano, entre cavalos empinados e granadeiros belos como Apolos, que expiram em atitude nobre! Foi assim em 1847; há-de ser assim em 1880.

No entanto, em desfiladeiro e monte, milhares de homens que, ou defendiam a pátria ou morriam pela «fronteira científica», lá ficam, pasto de corvos - o que não é, no Afeganistão, uma respeitável imagem de retórica: aí, são os corvos que nas cidades fazem a limpeza das ruas, comendo as imundícies, e em campos de batalha purificam 0 ar, devorando os restos das derrotas.

E de tanto sangue, tanta agonia, tanto luto, que resta por fim? Uma canção patriótica, uma estampa idiota nas salas de jantar, mais tarde uma linha de prosa numa página de crónica...

Consoladora filosofia das guerras!

No entanto, a Inglaterra goza por algum tempo a «grande vitória do Afeganistão» - com a certeza de ter de recomeçar, daqui a dez anos ou quinze anos; porque nem pode conquistar e anexar um vasto reino, que é grande como a França, nem pode consentir, colados à sua ilharga, uns poucos de milhões de homens fanáticos, batalhadores e hostis. A «política» portanto é debilitá-los periodicamente, com uma invasão arruinadora. São as fortes necessidades dum grande império.

Antes possuir apenas um quintalejo, com uma vaca para o leite e dois pés de alface para as merendas de verão...

A guerra, no discurso do presidente Obama, é o caminho para paz, algo bastante contraditório e nada original. Este foi o discurso usado pelos Estados Unidos ao entrar na Segunda Guerra Mundial e, a partir de então, se tornarem os salvadores do planeta, ou os pacificadores do planeta como podemos analisar em todas as suas guerras posteriores. Mesmo assim, ao receber o prêmio Nobel da paz, o discurso foi pela guerra. O que podemos crer é que existem interesses que impedem que a paz venha da maior potência imperialista do planeta.

Está guerra já está prestes a completar uma década, os resultados não são interessantes para o mundo e muito menos regionalmente, visto que a violência, com a presença estadunidense, só aumentou. A guerra contra o terror se transformou na guerra contra os Talibãs, contra a Al-Qaeda e 
contra o povo do Afeganistão que sofre com a morte de muitos civis. Até o momento, a ingerência da coalizão na região não trouxe a estabilidade política, não diminuiu a força dos Talibãs na região e não desmontou a organização terrorista Al-Qaeda. 


\section{CONSIDERAÇÕES FINAIS: A GEOGRAFIA MILITAR VERSUS O MILITARISMO.}

Não se pode julgar que a geografia militar, ou a ciência militar sejam as causas da guerra. Esse caminho teórico não é correto e é muito perigoso. A guerra como já disse Clausewitz é uma continuação da política por outros meios, isso nos dias de hoje, mesmo concordando com Keegan, que estrutura toda a sua tese para se contrapor a máxima central da Teoria da Guerra de Clausewitz. Então a causa das guerras é a política estabelecida pelos Estados, no caso pelos Estados Unidos, e não a formação dos exércitos e muito menos o estudo da geografia militar estas existem, pois é necessário que se defenda os interesses destas políticas, ou para que contraponham estas políticas.

Não podemos simplesmente descartar, nos dias atuais, as forças armadas para que se possa, pelo menos, estabelecer um plano de defesa de qualquer força que venha na tentativa de submeter à soberania do nosso país. Em nosso caso, devemos estar preparados para defender nossas riquezas e nossa liberdade e dividi-las com outros povos de maneira pacífica e harmônica, esta deveria ser a política de todos os Estados.

As palavras dos grandes sábios espirituais vão nesse sentido: não seria a sociedade ideal aquela em que as pessoas dividem com as outras tudo o que possuem e estão dispostas a servir todo mundo? Numa sociedade em que cada um quisesse trabalhar por todos não haveria mais necessidade de impostos e tarifas! E nem mais necessidade de política e de exército quando todos se dedicam a virtude!

Entretanto os Estados gastam suas riquezas e seus esforços criando armas de destruição em massa como a bomba atômica; destroem seus vizinhos; poluem a atmosfera do mundo inteiro, criam, em seu coração, o medo, o ódio, a desconfiança. Essa é a política pautada no militarismo, quando toda a sociedade esta voltada para os esforços da guerra. A sociedade estadunidense é uma sociedade militarizada, onde se gastam por ano mais de 600 bilhões de dólares em armas. Parece que os Estados Unidos não podem mais viver se não houver uma guerra, o discurso pela militarização se mescla 
com o discurso humanitário ao dizerem que o desarmamento e o fim dos investimentos bélico gerariam milhares de pessoas sem emprego, quando, na verdade, estudos como o de Vitor Perlo (1969) - Militarismo e Indústria: armamentos e lucro na era dos projéteis - apontam na direção contrária e dizem que se não fosse os altos investimentos do governo em indústrias que produzem armamentos nenhuma indústria produziria armas.

Então o conhecimento da geografia se faz necessário em caso de guerra contra as políticas imperialistas. Isto ocorreu no Vietnã, no Afeganistão, em Cuba, contra ditaduras pelo mundo todo, contra governos despóticos que massacram a população, a resistência se faz pelo conhecimento geográfico e como utilizá-lo em caso de guerra.

Até mesmo numa das passagens mais conhecidas da tradição hinduísta - reconhecida pelo aspecto da não-violência (ahimsa) - o Bhagavad Gita que conta a história de Arjuna que a beira da guerra, se recusa a lutar contra seus primos tiranos e, é convencido pelo supremo senhor Krishina a não fugir da guerra, pois seus primos tiranos só trariam tristeza e infelicidade para todo o mundo. $O$ que se fazer em caso de governos que submetem a população a desgraças? Uma população que não conhece o seu território está fadado a perdê-lo em caso de guerra. Uma nação que não sabe usar o território de maneira que este seja uma vantagem para si, não oferecerá resistência a usurpadores tirânicos que existem desde os tempos mais antigos, como já estudamos, até os dias atuais.

A geografia militar, portanto, é uma disciplina e não pode ser confundida com uma política. Ao trazer para discussão acadêmica uma disciplina antiga como essa, é criada a possibilidade de novas incursões no campo da geografia acadêmica como: geomorfologia, clima, hidrografia, biogeografia, com intuito de prospectar um campo de defesa no território. Isto seria uma geografia física aplicada às ciências militares. Por outro lado, a geografia humana contribuiria com estudos: regional; da distribuição da população, redes de comunicação e transporte, indústrias; a geografia urbana com estudos da cidade e sua apropriação e uso; o abastecimento de comida e suprimentos; as políticas territoriais; a geografia política. Todos esses conhecimentos poderiam ser usados para criação de uma política de defesa do território nacional, associando e apoiando teoricamente a ciência militar. 
Existem muitos caminhos que podem ser seguidos no campo da geografia militar e a associação de instituições civis e militares seriam o resultado mais benéfico para sociedade brasileira, principalmente, quando a questão é defesa do território nacional. A sociedade civil não pode ficar de braços cruzados e esperar que as decisões sejam tomadas de cima para baixo, temos que contribuir com o desenvolvimento científico. Esta pode ser a contribuição mais importante que a ciência geográfica pode realizar. 


\section{APOIO BIBLIOGRÁFICO}

ADVERSE, H (2006): Apresentação da edição brasileira. In: MAQUIAVEL, N. $\underline{A}$ arte da guerra. São Paulo, Martins Fontes, $1^{a}$ Ed. 251p.

ARON, R. (2002): Paz e guerra entre as nações. Trad. Sérgio Bath (1 $1^{\text {a }}$ edição) Brasília: Editora Universidade de Brasília, Instituto de Pesquisa de Relações Internacional; São Paulo: Imprensa Oficial do Estado de São Paulo, 2002, 936p.

. (1986): Pensar a guerra, Clausewitz. Trad. de Elisabeth Maia Speller Trajano. Brasília, Editora Universidade de Brasília, 322p.

BACKEUSER, E. (1952): A Geopolítica Geral e do Brasil. Rio de Janeiro, Biblioteca do Exército, 1952.

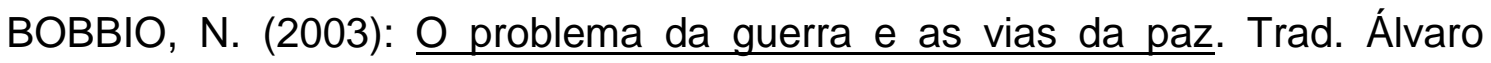
Lorencini. São Paulo: Editora UNESP, 2003.

BRIGAGÃO, C. (1983): A corrida para a morte: desarme o mundo armado. Rio de Janeiro. Nova Fronteira, 1983.

(1984): O mercado da segurança: ensaios sobre economia política de defesa. Rio de Janeiro. Nova Fronteira, 1984.

CEBRIAN, F.P. (1985): La geografia y la guerra: un analisis de sus relaciones. Madri: Servicio de Publicaciones Del EME, 1985.

CHIAVENATO, J.J. (1979): Genocídio Americano: A Guerra do Paraguai, Editora Brasiliense, 1979, São Paulo, 188p.

CLAUSEWITZ, Von C. (2003): Da Guerra. Trad. Maria Teresa Ramos. São Paulo: Martins Fontes, 2003, 930p. 
COLLINS, John M.(1998): Military Geography - for professionals and public. Washington, DC, 1998. National Defense University Press, 446 p.

COSTA, T. G. (1997): The Formation of defensive police in Brazil: Grand strategy and air power politics and doctrine during Cold War. Columbia University, 1997, 349p.

COSTA, W. M. (1992): Geografia Política e Geopolítica: discursos sobre o território e o poder. Ed. Hucitec, São Paulo, 1992.

COUTO E SILVA, G. (1967): Geopolítica do Brasil. Livraria Olympio, Rio de Janeiro, 1967, 266p.

DEMANT, P (2004): O Iraque dilacerado: uma corrida contra o relógio. In: Revista Panorama da Conjuntura Internacional - GACINT - n21, ano 6, maio.

FERNANDES, J.S. \& ANDRADER, P. (1984): Carros de Combate. Aquarius Editora e Distribuidora de Livros Ltda, São Paulo, 1984, 112p.

FINK, S. D. (2003): Origins of intervetion: western tradition of thinking about international politics and NATO's intervention in 1999 Kosovo crisis. A thesis presented to the Faculty of The Flecther Scholl of Law and Diplomacy.

FOSSATI, L. (1974): Rússia: pobre Nicky. In: As últimas monarquias. Instituto Geográfico De Agostini, Novara. São Paulo, Editora Três, 1974.

GILEWITCH, D. A. (2003): Military Geography: The Interaction of desert geomorphology and military operation. Arizona State University, 2003, 316p.

HARTH, A. C. (2003): Geopolitics and Grand Strategy: Foundations of American National Security. University of Pennsylvania, 2003, 475p. 
HART, B. H. L. (1967): As grandes guerras da história. São Paulo: IBRASA, 1967, 514p.

KEEGAN, J. (2006): Inteligência na guerra: conhecimento do inimigo, de Napoleão à Al-Qaeda. Trad. S. Duarte. São Paulo: Companhia das Letras, 448p.

(2005): A Guerra do Iraque. Trad. Laís Andrade. Rio de Janeiro: Biblioteca do Exército, 287p.

(1995): Uma história da guerra. Trad. Pedro Maia Soares. São Paulo: Companhia das Letras, 1995, 441p.

KENNEDY, P. (1989): Ascensão e queda das grandes potências: transformação econômica e conflito militar de 1500 a 2000. Trad. Waltensir Dutra. Rio de Janeiro: Elsevier, 1989.

KIMBLE, G.H.T. (2005): A geografia da Idade Média. São Paulo: Imprensa Oficial, 2005.

KISSINGER, H. (1994): Diplomacy. New York: Simon \& Schuster, 1994, 907p.

LACOSTE, Y. (2008): A geografia- isso serve em primeiro lugar, para fazer a Guerra. São Paulo, Papirus, 14º edição.

LAVALLÉE, T. (1865): Geógraphie physique, historique et militaire. Escola Especial de Saint-Cyr, $7^{7}$ edition, Paris, Charpentier Librairie - editeur, 1865.

LUTTWAK, E. N. (1987): Strategy: The logic of War and Peace. London: Harvard Univerty Press, 1987, 282p.

MCINTYRE, L. (1985): Humboldt's Way: Pioneer of Modern Geograph. In: National Geographic - September 1985, Vol. 168. 
MAGNOLI, D. (2006): História das Guerras. São Paulo: Contexto, 2006.

MAQUIAVEL, N. (2006): Arte da Guerra. São Paulo: Ed. Martins Fontes, $1^{\text {a }}$ Ed. 2006, 251p.

MARTIN, A.R. (2007): Brasil, Geopolítica e Poder Mundial - o anti-Golbery. Tese inédita para o concurso de obtenção do título de Livre Docente, São Paulo, março de 2007.

(2006): A guerra de secessão - in: MAGNOLI, D. Organizador. História das Guerras. São Paulo: Contexto, 2006

(2004): Geografia: Geopolítica e o poder mundial. CASTELLAR \& MARTINS, Organizadores. Pró-Universitário - Governo do Estado de São Paulo e Universidade de São Paulo.

MEDEIROS FILHO, O. (2004): Cenários geopolítico e emprego das forças armadas na América do Sul. Dissertação apresentada ao programa de pósgraduação em Geografia Humana do Departamento de Geografia da Faculdade de Filosofia, Letras e Ciências Humanas da Universidade de São Paulo para obtenção de título de Mestre em Geografia Humana.

MELLO, L. I. A. (1997): A geopolítica do Brasil e a Bacia do Prata. Manaus: Editora da Universidade do Amazonas, 1997.

(1999): Quem tem medo da Geopolítica? São Paulo: Editora Hucitec, 1999, 228p.

MORGENTHAU, H. J. (2003): A política entre as nações: a luta pelo poder e pela paz. Trad. Oswaldo Biato. Brasília: Editora Universidade de Brasília, Instituto de Pesquisa de Relações Internacional; São Paulo: Imprensa Oficial do Estado de São Paulo, 2003, 1152p. 
MORTON, L. (2004): Primeiro a Alemanha: o conceito básico da estratégia aliada na Segunda Guerra Mundial. In: Segunda Guerra Mundial: as grandes decisões estratégicas, Rio de Janeiro, BIBLEX, 2004, 512p.

PELEGRINO FILHO, Maj. A. (2002): A Influência da Missão Militar Francesa na ECEME. Rio de Janeiro, 2002, ECEME, 18p.

PELTIER \& PEARCY (1966): Military Geography. Princeton, New Jersey: D. Van Nostrand Company, INC. 1985, 176p.

PENHA, E. A. (1998): Relações Brasil-África e Geopolítica do Atlântico Sul Tese de Doutorado, UFRJ.

POMEROY, W.J. (1967): guerrillas y contraguerrillas - México D. F., Editorial Grijalbo, S. A.

PERLO, V. (1969): Militarismo e Indústria: armamentos e lucros na era dos projéteis. Trad. Eurico Remer \& Maura R. Sardinha. Rio de Janeiro, Paz e Terra.

PORRO, C.(1898): Guida allo studio della geografia militare; compendio delle lezioni di geografia militare. Torino: Unione tipografico-editrice, 1898[1903. VII, $391 p$.

RAPOPORT, A. (2003): Prefácio. In: CLAUSEWITZ; Da Guerra. São Paulo, Martins Fontes, 2 ${ }^{\mathrm{a}}$ Ed. $2^{\mathrm{a}}$ tiragem, 2003, 930p.

RANGEL, I. (1982): A economia dos anos 80. in: Ciclo, Tecnologia e Crescimento. Editora Civilização Brasileira, Rio de Janeiro, 1982, 172p.

RIBEIRO, W. C. (1994): Os militares e a defesa no Brasil: a indústria de armamentos. Dissertação de Mestrado. FFLCH da USP. São Paulo Orientador: Prof. Dr. José William Vesentini. 1994. 
ROBERT MORAES A.C. (1989): A gênese da Geografia Moderna. São Paulo: HUCITEC, Editora da Universidade de São Paulo, 1989.

.(1990): Organizador. Ratzel. São Paulo: Editora Ática, 1990.

RUDZIT, G. (1997): O processo de formação do Oficial do Exército brasileiro \& A Geografia (1850-1930). Dissertação de Mestrado apresentada ao Departamento de Geografia da Faculdade de Filosofia, Letras e Ciências Humanas da Universidade de São Paulo.

SUN TZU \& SUN PIN (2006): A arte da Guerra e Métodos Militares. Org. e trad. SAWYER: São Paulo, Ed. Martins Fontes, 1ํㅡㄹ Ed.4ํㅡ. Ed. 2006, 336p.

SAWYER, R. (2006): Org. e Trad. Introdução. In: SUN TZU \& SUN PIN. A arte da Guerra e Métodos Militares. São Paulo: Editora Martins Fontes, $1^{\text {a }}$ Ed. $4^{\text {a }}$ tiragem. 2006, 336p.

SANTOS, M. (1994): A natureza do espaço. São Paulo, Editora Hucitec, 1994.

TOYNBEE, A. (1923): A study of History. Royal Institute of International Affairs, Oxford University Press, Londres, 1923.

UNDERWOOD, JR \& GUTH, PL. (1998): Military Geology in War and Peace. Geological Society of America Reviews in Engineering Geology. Volume 13. Bounder, Colorado.

WINTERS W, GALLOWAY G. JR.,REYNOLD W, RHYNE D. (1998): Battling the Elements: Weather and Terrain in Conduct of War. John Hopkins University Press, Baltimore.

ZIMMER, H. (1986): Filosofias da Índia; compilado por Joseph Campbel; trad. versão final, Lia Diskin. São Paulo, Editora Palas Atenas, 1986. 


\section{Sites Pesquisados}

http://www.eceme.ensino.eb.br/posgraduacao/de Site PosGrad InterNet/de a rq/de arq RevistaCientificaOnLine/Artigo\%20em\%20PDF2002/spg 2.pdf

http://www.stratisc.org/Strategique 81

www.esao.ensino.eb.br/paginas/.../insuficiencia e abundancia-

www.militarypower.com.br/fram4-warVietn.htm -

http://www.globalsecurity.org/military/library/policy/army/fm/100-

7/f1007 13.htm,

www.resdal.org

www.onwar.com,

Artigos em sites:

P. Boulanger : De la géographie dans l'art de la guerre. L'école de géographie militaire française (XIXe - XXe siècles)

F. Botti : Naissance, développement et déclin de la géographie militaire en Italie $\underline{(X I X e-X X e ~ s i e ̀ c l e s) ~}$

P. Boulanger : L'un des pères fondateurs de la géographie militaire française : le commandant Anatole Marga (1843 - 1906)

H. de Weck : Le colonel Arnold Keller et la "géographie militaire de la Suisse"

G. Aselus : La géographie militaire suédoise et scandinave dans une perspective historique

T. Ene : La géographie militaire de la Roumanie (1850 - 1940) 
J. V. Borges : La géographie militaire au Portugal

J. Martin : La géographie militaire au Canada (1867-2002) 